MAÍRA FELONATO

IMPORTÂNCIA DA MOLÉCULA CD28 (MOLÉCULA CO-ESTIMULATÓRIA DE LINFÓCITOS T) NA PARACOCCIDIOIDOMICOSE PULMONAR. 


\section{MAÍRA FELONATO}

\section{IMPORTÂNCIA DA MOLÉCULA CD28 (MOLÉCULA CO-ESTIMULATÓRIA DE LINFÓCITOS T) NA PARACOCCIDIOIDOMICOSE PULMONAR.}

Dissertação de Mestrado apresentada ao Instituto de Ciências Biomédicas da Universidade de São Paulo, para obtenção do Título de Mestre em Ciências (Imunologia). 


\title{
IMPORTÂNCIA DA MOLÉCULA CD28 (MOLÉCULA CO-ESTIMULATÓRIA DE LINFÓCITOS T) NA PARACOCCIDIOIDOMICOSE PULMONAR).
}

\author{
Dissertação de Mestrado apresentada \\ ao Instituto de Ciências Biomédicas \\ da Universidade de São Paulo, para \\ obtenção do Título de Mestre em \\ Ciências. \\ Área de concentração: \\ Imunologia \\ Orientadora: \\ Profa. Dra. Vera Lúcia Garcia Calich
}

São Paulo

2007 


\section{UNIVERSIDADE DE SÃO PAULO \\ INSTITUTO DE CIÊNCIAS BIOMÉDICAS}

Candidato(a): $\quad$ Maíra Felonato.

Título da Dissertação: Importância da molécula CD28 (molécula co-estimulatória de linfócitos T) na Paracoccidioidomicose pulmonar.

Orientador(a): $\quad$ Vera Lucia Garcia Calich.

A Comissão Julgadora dos trabalhos de Defesa da Dissertação de Mestrado, em sessão pública realizada a

\section{( ) Aprovado(a) （ ) Reprovado(a)}

Examinador(a): Assinatura:

Nome:

Instituição:

Examinador(a): Assinatura:

Nome:

Instituição:

Presidente: Assinatura:

Nome:

Instituição: 
Aos meus familiares, em especial aos meus pais Natalino e Suely e ao meu marido Douglas com todo meu carinho e admiração. Obrigada pela dedicação e amor de todos estes anos. Vocês são meu exemplo de vida. 


\section{AGRADECIMENTOS}

A Deus por iluminar meu caminho e me dar forças para seguir sempre em frente. Por ser presença constante na minha vida, sem que eu precise pedir, pelo auxílio nas minhas escolhas e por me confortar nas horas difíceis.

À minha querida família, em especial a todos os meus tios pelo carinho, dedicação e apoio em todos os momentos de minha vida.

Ao meu pai Natalino Felonato e minha mãe Suely Alves Pinto Felonato por me incentivarem durante todos estes anos de minha vida e por me apoiarem sempre em todas as minhas decisões. Quanta saudade... E se hoje cheguei até aqui é porque tive pessoas de enorme caráter como vocês dois ao meu lado. Obrigada pela confiança, carinho e amor. Amo muito vocês.

Ao meu marido Douglas Mendes, pelo amor e paciência nos meus bons e "maus" momentos. Ao seu lado foi mais fácil transpor os dias de desânimo e desfrutar os dias de alegria. Te amo.

Ao meu avô Andrelino e a minha querida avó Joana Alves Pinto (in memorian) por estarem tão presentes em minha vida. Mesmo tão distantes sempre me apoiaram e me ajudaram. Obrigada por fazerem parte desta tão importante fase da minha vida.

Às minhas irmãs Mariana e Marina Felonato pelo carinho e alegria que sempre me proporcionam quando estamos juntas. Quanta saudade... Amo vocês!

À minha prima Thaís Alves Pinto pelo incentivo em não me deixar desistir nunca e pela verdadeira amizade de todos esses anos... Sem dúvida você faz parte deste trabalho. 
À minha orientadora Profa. Dra. Vera Lúcia Garcia Calich a quem tenho profundo respeito e enorme admiração. Agradeço aos importantes ensinamentos tanto científicos quanto pessoais, pela sincera amizade e pelo conforto nas horas difíceis. Obrigada por confiar e acreditar em mim. Você sem duvida tem um lugar muito especial no meu coração. Agradeço muito por ser a minha "mãe científica".

Ao meu sogro Gilberto, minha sogra Bernadete e minhas cunhadas Paula e Gisele Mendes por me receberem em sua casa e me tratarem como filha e irmã. Se não tivesse sido tão bem recebida o alcance deste trabalho teria sido mais complicado. Obrigada por tudo.

A duas pessoas no meu laboratório que depois destes dois anos de convivência deixamos de ser colegas para nos tornarmos grandes amigas. Às minhas "irmãs científicas" Adriana Pina e Simone Bernardino por estarem ao meu lado em todos os momentos difíceis, por dividirem comigo todas as minhas deficiências como pesquisadora, pelo apoio, discussões, companheirismo e pelo importante auxílio nos experimentos. Sem dúvida vocês ajudaram a me transformar na pesquisadora que sou. A vocês duas obrigada por tudo.

A todos os meus novos amigos Flávio Loures, Márcio Tomiyoshi, Clara Cavalcanti, Ana Paula dos Santos e Bruno Oliveira pelo apoio, por serem companheiros de viagens, pelas dicas nos experimentos e pelos momentos de muitas alegrias!

Às minhas colegas de laboratório Celina Arruda, Renata Scavone e Ângela Mickikaku, pela ajuda constante, carinho e pela certeza de que posso contar com elas sempre. Obrigada por toda dedicação prestada a este trabalho.

Aos pofessores Celidéia Copi Vaz, Maria José Mendes Giannini e ao pós-doutorando Luiz Sardinha pelas sugestões apresentadas no exame de qualificação.

Á Profa. Dra. Eva Burger por sua amizade e por sempre abrir as portas de seu laboratório. 
À Dra. Vera Capelozzi do Setor de Anatomia Patológica da Faculdade de Medicina da Universidade de São Paulo, pela ajuda na análise dos experimentos de histopatológico.

À Silvia Massironi e Regina de Lucca pelos cuidados e dedicação ao biotério, tão indispensáveis para a realização deste trabalho.

Ao Paulo Albe pela realização das lâminas para o estudo histopatológico.

Aos funcionários Claudia Cunha, Marlene Bernardes, Milton dos Santos, Otacílio dos Santos, Jotelma Ribeiro, Valéria Machado, Tânia Alves, por contribuírem na realização deste trabalho. Há vocês meu muito obrigado.

À Fundação de Amparo à Pesquisa do Estado de São Paulo (FAPESP) pelo apoio financeiro.

E a todos do Departamento de Imunologia, que de alguma forma contribuíram para a realização deste trabalho, seja pela ajuda constante ou por uma palavra de amizade! 
Quero, um dia, dizer às pessoas que nada foi em vão... que o amor existe, que vale a pena se doar às amizades e às pessoas, que a vida é bela sim e que eu sempre dei o melhor de mim... e que valeu a pena.

(Mário Quintana) 


\section{RESUMO}

FELONATO, M. Importância da molécula CD28 (molécula co-estimulatória de linfócitos T) na paracoccidioidomicose pulmonar. 2007. 96 fls. Dissertação (Mestrado em Imunologia) - Instituto de Ciências Biomédicas, Universidade de São Paulo, São Paulo, 2007.

CD28 é uma molécula co-estimulatória de linfócitos T que interage com antígenos CD80 e CD86 (B7-1/B7-2) expressos nas células apresentadoras de antígenos. Como a imunoproteção na Paracoccidioidomicose (PCM) é principalmente mediada pela imunidade de células $\mathrm{T}$, investigamos o impacto da deficiência da molécula CD28 na gravidade da infecção pulmonar e no padrão de anticorpos e citocinas produzidos pelos animais infectados com o fungo Paracoccidioides brasiliensis $(\mathrm{Pb})$. O efeito desta deficiência foi também estudado na imunoproteção induzida por uma prévia infecção pela via subcutânea (s.c.). Camundongos nocauteados para o gene CD28 (CD28KO) e controles normais (WT) da linhagem C57Bl/6 foram infectados pela via intratraqueal (i.t.) com $1 \times 10^{6}$ células de fungo e sacrificados 72 horas, 2 e 10 semanas pós-infecção. A carga fúngica foi avaliada pelo método de contagem das unidades formadoras de colônia (UFC) e a quantificação das citocinas e anticorpos pelo método de ELISA. Não foram observadas diferenças significantes entre as linhagens no período de 72 horas pósinfecção. Quando comparados com camundongos WT, os animais machos CD28KO apresentam na segunda semana de infecção, aumento da carga fúngica pulmonar associada a produção diminuída de IgM e das citocinas IL-2 e GM-CSF no fígado. Podemos ainda observar níveis mais elevados de IL-10 e GM-CSF no pulmão dos animais CD28-deficientes. Após 10 semanas de infecção, o aumento da carga fúngica nos animais CD28KO foi associada a diminuição da produção de anticorpos (IgM, IgG1, IgG2a, IgG2b), de IL-12 pulmonar e de IL-12, IFN- $\gamma$, IL-10 e GM-CSF hepática. A IL-5 foi a única citocina encontrada em níveis elevados no pulmão dos camundongos CD28KO. Camundongos CD28KO e WT desenvolveram imunoproteção equivalente quando pré-imunizados pela via s.c. e desafiados 15 dias depois com 1 milhão de leveduras. Além disso, a imunoproteção mostrou ser anticorpo-independente, pois este fenômeno foi observado em animais CD28KO cuja capacidade de produção de anticorpos mostrava-se bastante prejudicada. De maneira interessante, camundongos CD28KO apresentaram tempo de sobrevida significativamente maior que os animais WT embora os animais sobreviventes 
apresentassem grande crescimento fúngico tanto no pulmão como no fígado. Em contrapartida, os animais WT sobreviventes haviam eliminado completamente a carga fúngica tecidual. Mais uma vez, os animais CD28KO apresentaram capacidade diminuída de produzir anticorpos. Em conclusão, nosso trabalho mostrou pela primeira vez que a molécula CD28 exerce um importante papel regulatório na imunidade ao $P$. brasiliensis e a sua deficiência conduz a um processo infeccioso mais grave, porém não letal, associado a uma diminuição na produção de anticorpos e citocinas, provavelmente pela ativação deficiente de células T. Além disso, nossos estudos demonstraram que a carga fúngica elevada, na ausência da imunidade adaptativa efetora, não ocasiona a morte do hospedeiro infectado pelo P. brasiliensis, indicando claramente o duplo papel exercido pela resposta imune, que pode tanto proteger, como também induzir patologia com conseqüência grave na sobrevida dos hospedeiros.

Palavras chaves: Paracoccidioidomicose, CD28, citocinas, anticorpos, imunoproteção. 


\begin{abstract}
FELONATO, M. The role of CD28 deficiency, a T cell costimulatory molecule, in pulmonary paracoccidioidomycosis.. 2007. 96 fls. Dissertação (Mestrado em Imunologia) - Instituto de Ciências Biomédicas, Universidade de São Paulo, São Paulo, 2007.
\end{abstract}

CD28 is a costimulatory molecule of $\mathrm{T}$ cells that interacts with $\mathrm{B} 7-1 / \mathrm{B} 7-2$ antigens expressed by antigen presenting cells. As immunoprotection in PCM is mainly mediated by T cell immunity, we investigated the impact of CD28 deficiency in the severity of pulmonary infection and in the pattern of antibodies and cytokines secreted by Paracoccidioides brasiliensis $(\mathrm{Pb})$ infected mice. The effect of CD28 deficiency was also studied in the immunoprotection induced by a previous subcutaneous (s.c.) infection. Therefore, CD28KO and WT C57BL/6 mice were i.t. infected with $1 \times 10^{6}$ yeast cells and sacrificed 72 hours, 2 and 10 weeks post-infection. Fungal loads were analyzed by CFU counts and cytokines and antibodies by ELISA. No differences between KO and WT mice were seen $72 \mathrm{~h}$ after infection. By week 2, compared with WT counterparts, KO male mice presented higher pulmonary fungal burdens accompanied by decreased IgM, and low hepatic IL-2, and GM-CSF. IL-10 and GM-CSF were present in elevated amounts in the lung of CD28-deficient mice. At week 10, the increased fungal burden of $\mathrm{CD} 28 \mathrm{KO}$ was associated with decreased antibody production (IgM, IgG1, IgG2a, IgG2b) and diminished secretion of pulmonary IL-12 and hepatic IL-12, IFN- , IL-10 and GM-CSF. IL-5 was the only cytokine present in elevated levels in the lungs of CD28KO mice. Both, CD28 KO and WT mice developed equivalent immunoprotection when pre-immunized by the s.c. route. Immunoprotection, in addition, was shown to be antibody-independent since the phenomenon was seen in KO mice despite their impaired ability of antibody production. Interestingly, mortality studies revealed that exacerbated fungal burdens were not deleterious to KO mice since this mouse strain presented higher survival times when compared with WT mice. Again, CD28 KO survivors showed diminished ability of antibody secretion. In conclusion, our work showed for the first time that the CD28 molecule exerts an important regulatory role in PCM immunity and its deficiency leads to a more severe infection associated with decreased production of antibodies and cytokines probably due to the deficient $\mathrm{T}$ cell activation. Moreover, our studies demonstrated that high fungal burdens in the absence of effector adaptative immunity are not 
deleterious to P.brasiliensis infected hosts, clearly indicating the dual role played by the immune response, which can protect but can also induce life-threatening pathology.

Key words: Paracoccidioidomycosis, CD28, cytokines, antibodies, immunoprotection. 


\section{ILUSTRAÇÕES}

Figura 1 Fotografia do gel da PCR para caracterização dos genótipos C57Bl/6 selvagens e CD28KO

Figura 2 Avaliação da gravidade da doença por UFC após 72 horas, 2 e 10 semanas de infecção

Figura 3 Quantificação dos níveis de anticorpos após 2 e 10 semanas de infecção 30

Figura 4 Quantificação de citocinas tipo 1 pulmonares e hepáticas após 72 horas, 2 e 10 semanas de infecção

Figura 5 Quantificação de citocinas tipo 2 pulmonares e hepáticas após 72 horas, 2 e 10 semanas de infecção

Figura 6 Quantificação do fator de crescimento e da quimiocina pulmonares e hepáticas após 72 horas, 2 e 10 semanas de infecção

Figura 7 Quantificação dos níveis de NO após 72 horas, 2 e 10 semanas de infecção _ 36

$\begin{array}{lll}\text { Figura } 8 & \text { Avaliação do tempo de sobrevida __ } & 37\end{array}$

Figura 9 Avaliação da gravidade da doença por UFC do experimento de sobrevida _ 38

Figura 10 Quantificação dos níveis de anticorpos do experimento de sobrevida ___ 39

Figura 11 Quantificação de citocinas tipo 1 e tipo 2 pulmonares e hepáticas do experimento de sobrevida

Figura 12 Avaliação histopatológica das lesões pulmonares na segunda semana de infecção

Figura 13 Avaliação histopatológica das lesões pulmonares na décima semana de infecção

Figura 14 Avaliação histopatológica das lesões pulmonares do experimento de mortalidade

Figura 15 Avaliação da gravidade da doença por UFC do experimento de imunoproteção

Figura 16 Quantificação dos níveis de anticorpos do experimento de imunoproteção 46

Figura 17 Quantificação de citocinas tipo 1 e tipo 2 pulmonares e hepáticas do experimento de imunoproteção 


\section{ABREVIATURAS}

AcM

APC

BHI

CFA

CTLA-4

D.O.

ELISA

E.P.

FA

FJ

GM-CSF

i.p.

i.t.

ICAM-1

ICAM-2

ICOS

ICOSL

IFN $\gamma$

$\operatorname{Ig} \mathrm{A}$

$\operatorname{IgE}$

IgG

$\mathrm{IgG1}$

$\operatorname{IgG} 2 \mathrm{a}$

$\operatorname{IgG} 2 b$

IgG3

IgG4

IgM

IL-10

IL-12

IL-2
Anticorpo Monoclonal

"Antigen Presenting Cell"

"Brain Heart Infusion"

"Cell Free Antigen"

"Cytotoxic T Lymphocyte Antigen-4"

Densidade Óptica

"Ensyme-Linked Immunosorbent Assay"

Erro Padrão

Forma Adulta da Paracoccidioidomicose

Forma Juvenil da Paracoccidioidomicose

"Granulocyte Macrophage Colony Stimulating Factor"

Intraperitoneal

Intratraqueal

"Intercellular Adhesion Molecule-1"

"Intercellular Adhesion Molecule-2"

"Inducible Costimulator"

"Inducible Costimulator Ligand"

Interferon- $\gamma$

Imunoglobulina A

Imunoglobulina $\mathrm{E}$

Imunoglobulina $\mathrm{G}$

Imunoglobulina $\mathrm{G}$ isótipo 1

Imunoglobulina $\mathrm{G}$ isótipo 2a

Imunoglobulina $\mathrm{G}$ isótipo $2 \mathrm{~b}$

Imunoglobulina $\mathrm{G}$ isótipo 3

Imunoglobulina $\mathrm{G}$ isótipo 4

Imunoglobulina $\mathrm{M}$

Interleucina-10

Interleucina-12

Interleucina-2 


\begin{tabular}{|c|c|}
\hline IL-4 & Interleucina-4 \\
\hline IL-5 & Interleucina-5 \\
\hline iNOS & "Inducible Nitric Oxide Synthase" \\
\hline LFA-1 & "Lymphocyte Function Antigen-1" \\
\hline MCP-1 & "Macrophage Chemotatic Protein-1" \\
\hline MHC & "Major Histocompatibility Complex" \\
\hline ND & Não Dosado \\
\hline NO & "Nitric Oxide" \\
\hline NOS2 & "Nitric Oxide Synthase Type 2" \\
\hline OPD & Ortofenilenodiamina \\
\hline $\mathrm{Pb}$ & Paracoccidioides brasiliensis \\
\hline PBS & Solução salina em tampão fosfato $0,15 \mathrm{M}, \mathrm{pH} 7,2$ \\
\hline PCM & Paracoccidioidomicose \\
\hline PMN & Leucócitos Polimorfonucleares Neutrófilos \\
\hline SPF & "Specific Pathogen Free" \\
\hline STAT-4 & "Signal Transducers and Activators of Transcription" \\
\hline $\mathrm{T} \mathrm{CD}^{+}$ & Linfócito $\mathrm{T}$ auxiliar \\
\hline $\mathrm{T} \mathrm{CD}^{+}$ & Linfócito $\mathrm{T}$ citotóxico \\
\hline TCR & "T cell receptor" \\
\hline TNF- $\alpha$ & "Tumor Necrosis Factor $\alpha "$ \\
\hline TGF- $\beta$ & "Transforming growth factor $\beta "$ \\
\hline Th1 & Linfócitos T "helper” 1 \\
\hline Th2 & Linfócitos T “helper” 2 \\
\hline UFC & Unidades Formadoras de Colônias \\
\hline VCAM-1 & "Vascular cell adhesion molecule-1" \\
\hline
\end{tabular}




\section{SUMÁRIO}

1. INTRODUÇÃO___ 01

2. OBJETIVOS 13

3. MATERIAL E MÉTODOS__ 15

$\begin{array}{lll}3.1 & \text { ANIMAIS } & 16\end{array}$

$\begin{array}{lll}3.2 & \text { FUNGO } & 16\end{array}$

3.3 INFECÇÃO INTRATRAQUEAL__ 16

$\begin{array}{lll}3.4 & \text { INFECÇÃO SUBCUTÂNEA __ } & 17\end{array}$

3.5 DETERMINAÇÃO DAS UNIDADES FORMADORAS DE COLÔNIA (UFC)

3.6 DETERMINAÇÃO DO NÍVEL DOS ANTICORPOS ESPECÍFICOS___ 18

$\begin{array}{lll}3.6 .1 & \text { ANTÍGENO } & 18\end{array}$

$\begin{array}{lll}3.6 .2 & \text { ANTI-SOROS } & 19\end{array}$

$\begin{array}{lll}\text { 3.6.3 ENSAIO IMUNOENZIMÁTICO___ } & 19\end{array}$

3.7 DETERMINAÇÃO DOS NÍVEIS DE CITOCINAS

3.7.1 OBTENÇÃO DOS HOMOGENATOS DOS PULMÕES, FÍGADO E BAÇO__ 20

3.7.2 CARACTERIZAÇÃO DAS CITOCINAS: ELISA PARA QUANTIFICAÇÃO DE IL-2, IL-4, IL-5, IL-10, IL-12, TNF- $\alpha$, IFN- $\gamma$, TGF- $\beta$, MCP-1 e GM-CSF

3.7.3 DOSAGEM DAS CITOCINAS_ 21

3.8 CARACTERIZAÇÃO DO GENE DE CD28 POR PCR EM DNA GENÔMICO DE CAMUNDONGOS NORMAIS E DEFICIENTES PARA ESTA MOLÉCULA

$3.9 \quad$ DOSAGEM DE NO 23

3.10 DETERMINAÇÃO DO TEMPO MÉDIO DE SOBREVIDA___ 23

3.11 ANÁLISE HISTOPATOLÓGICA DOS PULMÕES___ 23 
4. RESULTADOS

4.1 CARACTERIZAÇÃO DO GENE DE CD28 POR PCR EM DNA GENÔMICO DE CAMUNDONGOS NORMAIS E DEFICIENTES PARA ESTA MOLÉCULA

4.2 AVALIAÇÃO DO GRAU DE INFECÇÃO PELA DETEMINAÇÃO DE UNIDADES FORMADORAS DE COLÔNIAS (UFC)

4.3 DETERMINAÇÃO DO NÍVEL DE ANTICORPOS ANTI-P. BRASILIENSIS

4.4 QUANTIFICAÇÃO DE CITOCINAS 30

4.4.1 CITOCINAS DO TIPO 1 EM PULMÃO E FÍGADO DOS CAMUNDONGOS CD28KO E CONTROLE

4.4.2 CITOCINAS DO TIPO 2 EM PULMÃO E FÍGADO DOS CAMUNDONGOS CD28KO E CONTROLE

4.4.3 NÍVEIS DO FATOR DE CRESCIMENTO GM-CSF E DA QUIMIOCINA MCP-1 NO PULMÃO E FÍGADO DOS CAMUNDONGOS CD28KO E CONTROLE

4.5 DOSAGEM DE NO

4.6 TEMPO DE SOBREVIDA

4.7 AVALIAÇÃO DO GRAU DE INFECÇÃO PELA DETERMINAÇÃO DE UNIDADES FORMADORAS DE COLÔNIAS (UFC) DOS ANIMAIS SOBREVIVENTES DO EXPERIMENTO DE MORTALIDADE

4.8 DETERMINAÇÃO DO NÍVEL DE ANTICORPOS ANTI-P. BRASILIENSIS NOS ANIMAIS SOBREVIVENTES DO EXPERIMENTO DE MORTALIDADE

4.9 ANÁLISE DAS CITOCINAS DE PULMÃO E FÍGADO DOS ANIMAIS SOBREVIVENTES DO EXPERIMENTO DE MORTALIDADE

4.10 ANÁLISE HISTOPATOLÓGICA 41

4.11 EXPERIMENTO DE IMUNOPROTEÇÃO: AVALIAÇÃO DA GRAVIDADE DA INFECÇÃO POR UFC 44 
4.12 EXPERIMENTO DE IMUNOPROTEÇÃO: DETERMINAÇÃO DO NÍVEL DE ANTICORPOS ANTI-P. BRASILIENSIS

4.13 EXPERIMENTO DE IMUNOPROTEÇÃO: ANÁLISE DAS CITOCINAS DE PULMÃO E FÍGADO

5. DISCUSSÃO 49

6. CONCLUSÃO 66

7. REFERÊNCIAS BIBLIOGRÁFICAS 68

8. ANEXOS 89

9. PUBLICAÇÃO 96 
INTRODUÇÃO 
A Paracoccidioidomicose (PCM), doença descrita por Lutz (1908), é causada pelo fungo dimórfico Paracoccidioides brasiliensis $(\mathrm{Pb})$. Esta infecção endêmica é prevalente na América Latina (revisado por Franco, 1987; Franco et al., 1989; Brummer et al., 1993), com maior incidência no Brasil, Venezuela, Colômbia e Argentina (Restrepo et al., 2001). No Brasil, é encontrada principalmente na região central do Estado de São Paulo, caracterizando uma extensa área endêmica (Blotta et al., 1999).

A PCM afeta principalmente as comunidades rurais, sendo nestas regiões uma das micoses profundas de maior incidência. Uma estimativa demonstrou que em uma região endêmica da América do Sul de aproximadamente 90 milhões de pessoas, 10 milhões estão em eminente risco de infecção. A doença apresenta grande magnitude e baixa visibilidade, sendo a oitava causa de morte por enfermidades crônicas entre as doenças infecto-parasitárias e a mais letal entre as micoses sistêmicas (McEwen et al., 1995).

O habitat natural do agente etiológico é exógeno ao homem, no entanto, ainda permanece pouco conhecido (Restrepo, 1985). Tem sido isolado de fezes de pingüim (Garcia et al., 1993), de ração de cachorro (Ferreira et al., 1990) e do solo (Albornoz, 1971; Negroni, 1966 e SilvaVergara et al., 1998). Acredita-se que micélios e conídios cresçam no solo, na água e nas plantas a temperatura ambiente e estas seriam as formas infectantes naturais do $\mathrm{Pb}$ (Restrepo, 1985).

O homem é o hospedeiro conhecido, capaz de desenvolver a doença se contaminando possivelmente através da via respiratória (González-Ochoa, 1972; Restrepo et al., 1970; Pupo, 1965). Outras vias infectantes foram também descritas, entre as quais a penetração do fungo ocorre através de tecido traumatizado (Soares \& Labuki, 1974; De Brito et al., 1973; Bopp, 1955). Alguns trabalhos relataram o isolamento do $\mathrm{Pb}$ a partir das vísceras de tatus (Dazypus novemcinctus), sugerindo que esses animais sejam o reservatório natural da PCM. Assim, Naiff et al. (1986) isolaram este fungo das vísceras destes animais que habitavam no interior do Pará. Posteriormente, Bagagli et al. (1998) também isolaram o fungo a partir das vísceras de tatus da região de Botucatu, interior de São Paulo. Todos os isolados obtidos destes animais foram em modelo experimental de hamster e mostraram similaridades micológicas, bioquímicas, antigênicas e moleculares com os isolados humanos (Sano et al., 1998-99a; Sano et al., 199899b). 
A PCM é considerada moléstia não contagiosa sem notificação compulsória, sendo assim difícil estimar o número exato de casos, entretanto, é suposto que em áreas endêmicas grande números de indivíduos possam ser infectados pelo fungo através da inalação de conídios infectantes que, atingindo os pulmões podem desenvolver o foco primário ou disseminar por via linfohematogênica em diferentes órgãos ou sistemas (Restrepo et al., 1988; Restrepo 1985). Em estudo epidemiológico realizado por Coutinho et al. (2002) relatou-se 3181 óbitos pela PCM no Brasil entre 1980 e 1995 sendo a taxa de mortalidade média anual de 1,45/1milhão de habitantes. A região do sudeste apresentou a taxa de mortalidade mais baixa com tendência de queda quando comparada com as outras regiões. Os dados indicaram também a prevalência da doença em áreas rurais e uma mortalidade predominante no sexo masculino em uma proporção de 562 homens/100 mulheres.

A PCM tem maior prevalência no sexo masculino e a maior incidência ocorre em homens com idade entre 30 e 50 anos, trabalhadores rurais que apresentam baixo nível sócio-econômico e um elevado grau de desnutrição, alcoolismo e tabagismo crônico, sendo raramente encontrada em crianças e jovens (Santos et al., 2003; Brummer et al., 1993; Aristizabal et al., 1998).

$\mathrm{O}$ baixo índice de mulheres portadoras da doença poderia ser explicado através dos efeitos hormonais femininos. Muchmore et al. (1974) demonstraram que o estradiol, um dos componentes hormonais femininos, inibe o crescimento das células leveduriformes. Loose et al. (1983) verificaram que o 17- $\beta$-estradiol (E2) reconhecia uma proteína receptora localizada na porção citosólica do fungo e que o E2 bloqueava a transformação da forma miceliar para a forma leveduriforme do fungo. Desta forma, a ação deste hormônio explicaria o fato da maior incidência da PCM doença no sexo masculino, pois o estradiol do hospedeiro inibiria a patogenicidade do P. brasiliensis. Além disso, estudos recentes demonstram que o 17- $\beta$ estradiol pode induzir in vitro a produção de óxido nítrico (NO) e aumento da expressão da enzima óxido nítrico-sintase induzida (iNOS) em macrófagos peritoneais (Hong \& Zhu, 2004). Como a morte intracelular do P. brasiliensis parece ser mediada pela produção de óxido nítrico (Gonzalez et al., 2007) este fato poderia explicar, ao menos parcialmente, a menor susceptibilidade do sexo feminino à PCM. 


\section{INTRODUÇÃO}

A infecção pelo $P$. brasiliensis é geralmente adquirida pela via respiratória, provavelmente pela inalação de propágulos aéreos do fungo (conídio) (McEwen et al., 1987). In vitro e provavelmente na natureza, o fungo é encontrado como micélio ou esporo (E) à temperatura ambiente, ou na forma de levedura em temperatura a $37^{\circ} \mathrm{C}$ sendo esta a forma predominante em tecidos de pacientes (Restrepo, 1985; Restrepo, et al., 1988). Na PCM-infecção não há produção de anticorpos, mas a resposta imune celular está presente.

Uma vez que o sistema imune do hospedeiro entra em contato com o fungo, características do indivíduo (idade, sexo, estado nutricional entre outras), do fungo (virulência e antigenicidade) e da interação entre eles contribuirão para que se instale a PCM-infecção ou a PCM-doença (revisado por Franco et al., 1993).

A maioria dos indivíduos infectados usualmente desenvolvem infecção pulmonar assintomática caracterizando a PCM-infecção. Neste caso, a infecção se localiza nos pulmões ou em tecido mucocutâneo e o foco infeccioso pode desaparecer (Franco, 1987). A infecção também pode evoluir de assintomática para progressiva, com disseminação para vários órgãos, causando diversas lesões; este quadro caracteriza a PCM-doença a qual pode evoluir para a forma aguda ou subaguda ou para a forma crônica que pode ser subdividida em branda, moderada e grave (Franco, 1987). A forma aguda ou juvenil (FJ) da doença apresenta disseminação sistêmica, com hipertrofia do baço, fígado, linfonodos e alteração da medula-óssea. Esta forma clínica representa cerca de 3 a 5\% dos casos, é mais freqüente em jovens com idade inferior aos 30 anos (Franco et al., 1989; Brummer et al., 1993) e os pacientes apresentam predomínio de citocinas do padrão Th2, altos níveis de anticorpos específicos e isótipo IgE, eosinofilia e resposta imune celular suprimida (Mota et al., 1985; Benard et al., 1997). Nesta mesma linha, trabalho desenvolvido por Mamoni et al. (2002) também mostrou que pacientes com FJ desenvolvem níveis aumentados de IgG4, IgE, IgA e TGF- $\beta$.

Por outro lado, a forma crônica ou adulta (FA) representa cerca de $90 \%$ dos casos, é freqüente em homens adultos, apresenta curso lento, comprometimento pulmonar, disseminação que pode afetar mucosas, linfonodos, adrenais e, menos freqüentemente, o sistema nervoso central, medula e órgãos genitais (Franco et al., 1989; Brummer et al., 1993). Pacientes com a FA menos grave apresentam níveis elevados de citocinas do padrão Th1 ( IFN- $\gamma$ ) além de 
INTRODUÇÃO

anticorpos específicos IgG2 e IgA (imunoglobulina de mucosa), sugerindo certo controle da infecção e doença menos grave (Baida et al., 1999).

Geralmente, com a evolução da forma grave da doença, há depressão da imunidade celular e elevação dos títulos de anticorpos específicos (Motta et al., 1985; Biagioni et al., 1984). Há também diferenças marcantes nos achados histopatológicos. Na forma benigna da doença aparecem granulomas epitelióides compactos e na forma grave os granulomas são frouxos, supurativos com numerosas células fúngicas (Fava Netto \& Raphael, 1961).

Do ponto de vista da resposta imunológica, os pacientes paracoccidioidomicóticos têm sido classificados em duas formas polares (Lacaz et al., 1982). Na primeira forma ou no pólo hiperérgico, a PCM se apresenta como uma forma benigna da doença e a infecção é geralmente localizada; o hospedeiro apresenta resposta imune celular preservada, baixos títulos de anticorpos e os achados histopatológicos mostram a formação de granulomas epitelióides compactos contendo poucos fungos. Na segunda forma, o chamado pólo anérgico, a PCM se apresenta como uma forma maligna da micose, com disseminação da infecção a vários tecidos e órgãos, resposta celular deprimida e altos níveis de anticorpos específicos; apresenta na histologia áreas de inflamação granulomatosa mista (frouxa e supurativa) com extensas áreas de necrose e abundantes células do fungo.

Vários estudos demonstram que a resposta imune celular e a ativação de fagócitos têm um papel fundamental na defesa dos hospedeiros contra a infecção pelo $P$. brasiliensis, enquanto que as formas mais graves da doença estão associadas a níveis altos de anticorpos e ativação policlonal de linfócitos B (Arango \& Yarzabal, 1982; Castañeda et al., 1988; Fazioli, 1997; Motta et al., 1985; Singer-Vermes et al., 1993; Kashino et al., 1990). Estas características indicam que a resposta imune humoral governada por linfócitos T "helper" 2 (Th2), conduzem a uma doença mais grave ao contrário daquelas associadas com a ativação da imunidade celular, comandada pelos linfócitos T "helper" 1 (Th1), que levam a uma patologia mais branda (Calich et al. 1994).

Vários trabalhos têm demonstrado que pacientes com a forma grave da PCM produzem níveis de IgE, IgG4 (regulados por IL-4) e IgA (regulada pelo TGF- $\beta$, IL-5 e IL-10) mais elevados do que aqueles com a forma branda da doença (Baida et al., 1999; Mamoni et al., 2002). Além disso, a secreção de níveis mais altos de citocinas do tipo 2 ( IL-4, IL-5, IL-10 ) e TGF- $\beta$ 
INTRODUÇÃO

(bem como a presença de eosinofilia), foi detectada em pacientes com infecção mais disseminada do que aqueles com a doença menos grave (Oliveira et al., 2002). Em pacientes com a doença ativa, foi encontrada diminuição na secreção de IFN- $\gamma$ (Oliveira et al., 2002; Karhawi et al., 2000) e o aumento da expressão de CTLA-4 em células mononucleares do sangue periférico, aumento este que pode estar relacionado com a anergia dos linfócitos $\mathrm{T}$ (Campanelli et al., 2003). Em conjunto, estes dados indicam um padrão de resposta imune Th1/Th2 na PCM, isto é, as células Th2 associadas com a doença progressiva e grave e as células Th1 associadas com a forma benigna da infecção. Alternativamente, a anergia de células $\mathrm{T}$ poderia ser a responsável pela resposta imune inadequada de pacientes com a forma grave.

Estudos realizados através de uma inoculação intraperitoneal (i.p.) do $P$. brasiliensis demonstraram padrões distintos de susceptibilidade, estabelecendo que camundongos B10.A são susceptíveis e camundongos $\mathrm{A} / \mathrm{J}$ são resistentes ao fungo. A característica importante deste modelo é a similaridade com a doença humana, sendo que a linhagem B10.A mimetiza a doença progressiva e a A/J mostra um padrão regressivo ou localizado da infecção (Calich et al., 1994, Calich \& Kashino, 1998). Postulou-se através deste modelo que a resistência na PCM estava associada com a ativação preferencial de linfócitos Th1 ao contrário da susceptibilidade que estaria associada com a inativação de células $\mathrm{T}$ ou a ativação preferencial das células Th2 (Calich et al., 1994; Murphy et al., 1994). Na infecção intratraqueal (i.t.) os padrões de susceptibilidade e resistência observados no modelo intraperitoneal foram mantidos, sugerindo que a resistência à PCM estava associada à atividade de linfócitos $\mathrm{T}$, macrófagos e linfócitos mediados pelo IFN- $\gamma$ (Cano et al., 1995). Neste modelo, demonstrou-se ainda que o IFN- $\gamma$ é a principal citocina imunoprotetora (Cano et al. 1998) uma vez que a depleção de IFN- $\gamma$ por anticorpos monoclonais agravou a doença, tanto em animais susceptíveis, como em animais resistentes ao fungo. Nos animais depletados houve aumento da carga fúngica pulmonar e anergia da resposta imune celular.

Souto et al. (2000) ao estudarem o papel do IFN- $\gamma$ e fator de necrose tumoral-alfa (TNF-

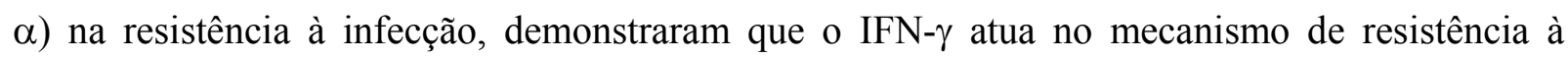
doença e induz a produção de óxido nítrico que determina anergia de células T. Outros estudos 
INTRODUÇÃO

revelaram que a produção de quimiocinas e o recrutamento de leucócitos para os pulmões em camundongos infectados por P. brasiliensis são modulados por IFN- $\gamma$. Souto et al. (2003) evidenciaram isto ao estudar a produção de quimiocinas em camundongos C57B1/6 comparados a animais da mesma linhagem, porém com o gene para IFN- $\gamma$ nocauteado. Estes últimos produziram baixos níveis de quimioatraentes para células mononucleares como as quimiocinas IP-10, Mig e MCP-1, e níveis altos de quimioatraentes de neutrófilos como KC e MIP-1 $\alpha$.

Estudos realizados com o modelo intra-peritoneal e com o modelo pulmonar da PCM demonstraram que a infecção pelo $P$. brasiliensis leva a diferentes graus de ativação macrofágica e que esta depende do padrão genético da linhagem de camundongo empregada (Kashino et al., 1995).

O óxido nítrico, um dos mais importantes intermediários reativos de nitrogênio, é um dos principais responsáveis pela atividade microbicida dos macrófagos, sendo gerado pela oxidação de um dos nitrogênios do aminoácido L-arginina (Hibbs et al., 1987). A enzima óxido-nítricosintetase induzida (iNOS ou NOS2) é a responsável pela produção de NO e está amplamente envolvida em processos inflamatórios e infecciosos (McMicking et al., 1997). Muitos estudos têm demonstrado a participação do NO em várias infecções por microrganismos, inclusive pelo P. brasiliensis. Bocca et al. (1998) demonstraram que o tratamento in vivo com um inibidor de NO agravava a doença em camundongos (C57B1/6) infectados pelo P. brasiliensis, porém revertia a anergia dos linfócitos $\mathrm{T}$ a antígenos do fungo.

Nascimento et al. (2002) relataram que macrófagos de animais resistentes produzem baixos níveis de NO e altos de TNF- $\alpha$, enquanto que camundongos susceptíveis estimulados por leveduras vivas do fungo produzem níveis elevados de NO e baixos de TNF- $\alpha$. Além disso, em animais cuja síntese de NO foi inibida in vivo e em camundongos deficientes do gene de iNOS a doença foi mais grave com lesões disseminadas e ricas em fungos. Foi também demonstrado que a produção exacerbada de NO levava à inibição de linfócitos T (Bocca et al., 1998).

Trabalhos recentes desenvolvidos em nosso laboratório demonstraram que a citocina IL-4 (a mais típica citocina Th2) tem uma dupla função na PCM: dependendo do padrão genético do hospedeiro esta citocina pode ser protetora ou exacerbadora da doença pulmonar (Arruda et al., 2004; Pina et al., 2004). Os leucócitos PMN têm ação evidente na imunidade protetora de 
INTRODUÇÃO

camundongos susceptíveis embora protejam camundongos resistentes somente ao início da infecção. Fato interessante observado neste trabalho foi o de que a depleção de leucócitos PMN induzia doença muito grave nos camundongos susceptíveis em concomitância com níveis elevados de citocinas pró-inflamatórias. Assim, a ativação excessiva do sistema imune pode ser deletéria ao hospedeiro (Pina et al., 2006).

Por outro lado, as citocinas IL-12 e IFN- $\gamma$ exercem um efeito protetor contra a doença. Como citado anteriormente, a depleção in vivo desta última citocina exacerba a doença tanto em camundongos susceptíveis como resistentes (Cano et al., 1998). Além disso, o tratamento de animais susceptíveis com IL-12 recombinante leva a doença menos grave, com síntese de níveis mais elevados de IFN- $\gamma$ ao início da infecção e produção de anticorpos específicos assim como de citocinas Th1 e Th2 em quantidades menores em fases mais tardias da doença. A IL-12 exógena apesar de diminuir a carga fúngica nos órgãos de disseminação (fígado e baço), induz aumento evidente do infiltrado inflamatório pulmonar. Por outro lado, a depleção de IL-12 endógena por AcM específicos levou a doença mais grave tanto nos animais susceptíveis como nos resistentes. Confirmando o efeito protetor da IL-12 na PCM, verificou-se que a doença em camundongos IL-12 KO é extremamente grave e leva à morte precoce dos animais (Calich et al., 1998; Deepe et al., 2000).

A IL-10 parece ser uma citocina que tem alto desempenho no processo de exacerbação da doença. A PCM em animais IL-10 KO é muito menos grave quando comparada com aquela desenvolvida por animais C57BL/6 controle, e apresenta um padrão regressivo tanto em relação ao número de fungos como em relação ao aspecto de lesões pulmonares. Além disso, a ausência geneticamente determinada de IL-10 impede a disseminação do fungo para o fígado e baço (Alves \& Calich, dados não publicados).

Os estudos referentes à participação dos linfócitos $\mathrm{TCD}^{+}$e $\mathrm{TCD} 8^{+}$na $\mathrm{PCM}$ são escassos e indiretos (Calich \& Blotta, 2005). Ao contrário do que se supunha na doença humana, experimentos de depleção in vivo e com camundongos nocaute (KO) para genes das moléculas CD4 e CD8 $\alpha$ têm demonstrado que os linfócitos $\mathrm{T} \mathrm{CD}^{+}$são fundamentais para o controle da PCM pulmonar e podem se apresentar sob os padrões do tipo 1 (secretor de IFN- $\gamma$ ) ou tipo 2 (secretor de IL-4) de ativação. Além isso, estes linfócitos parecem ser fundamentais para 
INTRODUÇÃO

o controle da carga fúngica pulmonar (Cano et al., 2000; Chiarella et al., 2007; Calich \& Blotta, 2005). Os linfócitos T $\mathrm{CD}^{+}$do tipo 1 são ativados ao início da resposta imune de camundongos resistentes que mais tardiamente ativam subpopulações Th2. Esta ativação parece contribuir para o padrão de resistência, talvez regulando negativamente o processo inflamatório lesivo para tecidos do hospedeiro. A subpopulação $\mathrm{T} \mathrm{CD}^{+}$de camundongos susceptíveis é completamente anérgica e a doença destes animais não se altera pela depleção seletiva de linfócitos T CD4 $4^{+}$. Assim, em camundongos susceptíveis outros mecanismos imunorregulatórios parecem estar associados à susceptibilidade genética à doença. Neste aspecto, trabalhos recentes realizados com pacientes têm demonstrado que a imunossupressão na PCM está associada à expressão aumentada de moléculas CTLA-4 por linfócitos de pacientes (Campanelli et al., 2003), à apoptose de células $\mathrm{T}$ (Cacere et al., 2002) e à ação de células T-reguladoras de fenótipo T $\mathrm{CD}^{+} \mathrm{CD} 25^{+}$Foxp3 $^{+}$(Cavassani, 2006).

O estudo das citocinas no curso de PCM pulmonar demonstra que na fase de imunidade adquirida as do tipo 1 ou pró-inflamatórias (IFN- $\gamma$, IL-12, IL-2) estão associadas com fenômenos imunológicos imunoprotetores enquanto que IL-4 e IL-10 (principalmente esta última) parecem determinar doenças mais graves e progressivas. Este fato também foi demonstrado em pacientes. A PCM infecção representa o pólo Th1 com síntese de IFN- $\gamma$, IL-2, IL-12 e imunidade celular desenvolvida. Os pacientes com a forma juvenil representam o pólo Th2, pois há a síntese de IL-5, IL-4, IL-10 e TGF- $\beta$ em níveis bastante elevados, além de ausência de imunidade celular. Nos indivíduos com a PCM crônica (que representam cerca de 90\% do total de doentes) não há um perfil típico. Parece haver tendência Th2 nos casos mais graves (Mamoni et al., 2001).

Uma visão em conjunto do modelo genético murino de PCM indica que o paradigma Th1/Th2 de ativação da resposta imune adaptativa não explica completamente os fenômenos de resistência e susceptibilidade ao fungo. Neste modelo demonstrou-se que o IFN- $\gamma$ é a principal citocina imunoprotetora (Cano et al. 1998); que a IL-12 também confere proteção aos animais infectados (Arruda et al. 2002; Deepe et al., 2000); que a IL-4 pode ser protetora ou exacerbadora da doença dependendo do padrão genético do hospedeiro (Pina et al. 2004; Arruda et al. 2004); que a produção de NO é fundamental para a atividade microbicida dos fagócitos, mas a sua 
produção exacerbada leva à inibição de linfócitos T (Bocca et al., 1998; Nascimento et al. 2002); que linfócitos $\mathrm{T} \mathrm{CD}^{+}$e $\mathrm{T} \mathrm{CD}^{+}$participam ativamente dos processos de imunoproteção na infecção primária e secundária (Calich e Blotta, 2005); e que a maioria dos antígenos que estimuam linfócitos B na PCM são T-dependentes (Burger et al., 1996).

Para que as células do sistema imunológico sejam ativadas é necessário que ocorra uma interação entre moléculas presentes nos linfócitos $\mathrm{T}$ e em células apresentadoras de antígenos (APCs). Dois sinais são necessários para que a ativação de linfócitos $\mathrm{T}$ aconteça. $\mathrm{A}$ interação entre o complexo TCR do linfócito T com o epítopo exposto pela APC através da molécula de histocompatibilidade principal (MHC de classe I para linfócitos T $\mathrm{CD} 4^{+}$e MHC de classe II para linfócitos $\mathrm{T} \mathrm{CD}^{+}$) constitui o primeiro sinal. $\mathrm{O}$ segundo sinal que depende de um balanço de interações entre moléculas co-estimulatórias ou inibitórias presentes nas células apresentadoras de antígenos (APC) e nos linfócitos T (Mueller et al., 1989; Bretscher, 1982). Dentre as moléculas co-estimulatórias, a molécula CD28 expressa no linfócito $\mathrm{T}$ interage com as moléculas B7-1/B7-2 expressas nas APC. Outras moléculas acessórias ou de adesão tais como LFA-1, ICAM-1/2, CD40 e CD40L contribuem para esta interação. Após ambos os sinais, a célula $\mathrm{T}$ é capaz de entrar em processo de proliferação e diferenciar-se em células efetoras e de memória capazes de responder ao antígeno, seja ele um microrganismo ou não.

Sabemos atualmente que a molécula CD28 fornece "um segundo sinal potencial" requerido para a ativação da célula $T$ após a sua ligação aos seus ligantes naturais B7-1 (CD80) ou B7-2 (CD86) presentes nas APC (June et al., 1994) e que apenas estes ligantes poderiam interagir com o CD28 e ativar constitutivamente as células T (Gaglia et al., 2000). A ligação de moléculas B7 à molécula CTLA-4 (“Cytotoxic T Lymphocyte Antigen-4", molécula homóloga a CD28) expressa nas APC pode levar a um processo de anergia, tolerância ou desativação celular, e esta interação pode ser considerada um mecanismo regulador da ativação de linfócitos T (Rudd \& Schneider, 2003).

A molécula ICOS ("Inducible Costimulator Protein", homóloga de CD28, a qual é constitutiva de células T) tem sua expressão induzida após a ocupação do TCR e liga-se a 
INTRODUÇÃO

ICOS - Ligante (ICOSL), sendo este par co-estimulatório particularmente importante na regulação de produção de citocinas por células $\mathrm{T}$ (Th1 e Th2) recentemente ativadas por células efetoras (Sharpe \& Freeman, 2002). Nas respostas de células Th2 de memória, a sinalização mediada por ICOS/ICOSL é particularmente importante, e dispensa a interação CD28/B7 (Iezzi et al., 1998). Controla principalmente a produção de citocinas por linfócitos $\mathrm{T}$ recém ativados, porém é menos eficaz na ativação de linfócitos $\mathrm{T}$ virgens, cuja ativação inicial parece ser estritamente dependente da co-estimulação pela molécula CD28 (Hutloff et al., 1999, Nurieva et al., 2003).

Alguns autores referem que, na ausência de CD28, a molécula de adesão ICAM-1 (ligante da integrina LFA-1) é requerida e pode estimular preferencialmente os linfócitos $\mathrm{T}$ CD8 $8^{+}$. Quando há expressão insuficiente de ICAM-1, a importância do CD28 na adesão celular mostra-se aumentada (Life et al., 1995); entretanto, ICAM-1 não é suficiente para a coestimulação de células T (Hagerty, 1996) ou para induzir a síntese de IL-2 (Boussiotis et al., 1993), tornando difícil classificar a ação final de tal molécula de adesão.

Tem sido descrita a importância da ativação celular dependente da molécula CD28 em diversas patologias. Mathur et al. (1999) relatam o papel central de CD28 na indução da resposta Th2 e na produção de anticorpos após a infecção das vias aéreas de camundongos com o helminto Shistossoma mansoni. Em infecções por outros patógenos (vírus, protozoários) os sinais mediados por CD28 têm pequena importância na diferenciação das subpopulações Th1 e Th2 de linfócitos (Broun, et al., 1996). Estudos recentes mostraram que, embora o CD28 seja requerido para as respostas de linfócitos $\mathrm{T}$ durante a toxoplasmose, a interação entre outras moléculas co-estimulatórias com ação semelhante à do CD28 podia levar à produção de linfócitos T e de IFN- $\gamma$ durante a fase aguda da toxoplasmose.

Villegas et al. (1999) verificam que, apesar de existirem moléculas co-estimulatórias alternativas, existe a exigência da molécula co-estimulatória CD28 para o desenvolvimento da resposta de linfócito $\mathrm{T}$ de memória após a infecção pelo T. gondii. Contudo, estudos que examinaram as respostas de linfócitos $\mathrm{T}$ ao vírus da influenza e ao Haemophylus polygyrus em camundongos $\mathrm{CD} 28 \mathrm{KO}$ indicaram que a indução da memória nos linfócitos $\mathrm{T}$ não requeria CD28 (Liu et al., 1997; Gause et al., 1997). 
INTRODUÇÃO

Recentemente, Elias et al. (2005), estudaram o papel de CD28 na resposta imune primária e secundária ao Plasmodium chabaudi, focalizando a ativação policlonal de linfócitos e a geração das respostas patógeno-específicas. Verificaram que a ausência de CD28 não alterava a expansão de linfócitos $\mathrm{T}$ e $\mathrm{B}$, e que na fase aguda da doença a resposta policlonal de produção de IgM era independente de CD28; verificou-se porém, que a produção policlonal de IgG2a é influenciada por este co-receptor. A ausência de CD28 não alterou a eliminação do parasita na fase aguda, porém impediu a erradicação do mesmo numa segunda infecção. Além disso, animais CD28 KO não desenvolveram níveis adequados de células $\mathrm{T}$ de memória. Assim, ficou demonstrado que a molécula co-estimulatória CD28 é necessária para o desenvolvimento adequado da imunidade T e B específicas e protetoras ao P. chabaudi.

Dados da literatura (Campanelli et al., 2003) mostram o envolvimento da molécula regulatória de linfócitos T ativados - CTLA-4 - durante a infecção pelo P. brasiliensis nos seres humanos. A expressão desta molécula e do sistema Fas-FasL estavam aumentados na cultura de leucócitos de pacientes com a infecção; após a adição de anticorpos monoclonais que inibem as moléculas CTLA-4 e Faz observou-se um aumento significativo na resposta proliferativa de linfócitos T. Verificaram também que a expressão da molécula CD28 era semelhante entre os grupos de pacientes infectados e os controles, mesmo após a cultura com o antígeno fúngico. Em suma, os dados deste trabalho mostraram que a apoptose de linfócitos mediada pela interação entre as moléculas Fas-FasL e a inibição linfocitária dirigida pela interação entre o CTLA-4 ao seu ligante estão envolvidos na modulação da resposta imune durante a infecção pelo $P$. brasiliensis em humanos.

Assim, o estudo da função da molécula co-estimulatória CD28 no desenvolvimento da resposta imune nas fases aguda e crônica da PCM pretende esclarecer se esta molécula está envolvida na ativação celular induzida pelo fungo e se contribui para a imunoproteção e eliminação do P. brasiliensis dos tecidos. 
OBJETIVOS 
Considerando-se que:

1- na PCM pulmonar a ativação de linfócitos $\mathrm{T}$ e fagócitos é fundamental para o controle da doença;

2- a gravidade da PCM está associada à síntese de altos níveis de anticorpos;

3- a maioria dos antígenos do fungo que induz a síntese de anticorpos é T-dependente;

4- a polarização da resposta de linfócitos $\mathrm{T}$ para Th1 ou Th2 determina padrões mais ou menos graves da doença;

5- a anergia de células T e a síntese prejudicada de IL-2 estão associadas às formas graves da PCM;

6- a PCM é uma patologia extremamente crônica e a sua resolução ou controle depende da ação de células $\mathrm{T}$ de memória e células $\mathrm{T}$ efetoras $P$.brasiliensis-específicas; e, finalmente,

7- a interação das moléculas co-estimulatórias CD28/B7 pode afetar todos estes parâmetros, decidimos investigar a função da molécula CD28 na resistência de camundongos à infecção i.t. pelo P.brasiliensis.

O objetivo geral do nosso trabalho é avaliar a importância da molécula CD28 tanto na fase de imunidade inata quanto na de imunidade adaptativa da paracoccidioidomicose desenvolvida por camundongos geneticamente deficientes de molécula CD28 (CD28 KO) em comparação aos seus controles selvagens (controle - WT), ambos da linhagem C57Bl/6J. Para atingir este objetivo os animais CD28KO e seus controles normais foram estudados comparativamente quanto:

a) a carga fúngica presente nos pulmões e a disseminação para o baço e fígado através da técnica de Unidades Formadoras de Colônia (UFC) padronizada em nosso laboratório;

b) ao tempo médio de sobrevida após a infecção;

c) a produção de anticorpos na resposta imune adaptativa;

d) a produção de citocinas e óxido nítrico no pulmão e fígado;

e) a morfologia das lesões pulmonares e dos órgãos de disseminação por análise histológica;

f) ao desenvolvimento de imunidade protetora após um desafio secundário com o fungo. 
MATERIAL E MÉTODOS 


\subsection{ANIMAIS}

Camundongos machos da linhagem C57B1/6 (controle - WT) e da linhagem C57Bl/6 deficientes para a molécula co-estimulatória CD28 (CD28KO) foram utilizados quando atingiam a faixa etária entre 8 e 11 semanas de idade. Os animais foram criados em condições livres de patógenos (SPF) no Biotério de camundongos Isogênicos do Departamento de Imunologia do ICB-USP e manuseados de acordo com as normas do comitê de ética do mesmo departamento.

\subsection{FUNGO}

Foi utilizado o isolado $\mathrm{Pb} 18$ (virulento) do P. brasiliensis (Kashino et al., 1985; SingerVermes et al., 1989). A perda da virulência tem sido evitada renovando-se periodicamente a amostra de $\mathrm{Pb} 18$. Novas amostras do fungo são obtidas e reisoladas após passagens sucessivas em camundongos B10.A machos (susceptíveis) após 3 meses de infecção.

O fungo foi mantido por repiques semanais em meio semi-sólido de Fava Neto (Fava Neto, 1955) a $36^{\circ} \mathrm{C}$. Após uma semana de cultivo era obtida uma suspensão celular que era lavada três vezes em solução de salina estéril (PBS estéril). A concentração celular fúngica (1 x $10^{6}$ células $/ \mathrm{mL}$ ) foi ajustada tomando-se por base a contagem em câmara hemocitométrica e a viabilidade da suspensão celular foi avaliada utilizando-se o corante vital Verde-Janus B que foi sempre superior a 80\% ( Berliner \& Reca, 1966).

\subsection{INFECÇÃO INTRATRAQUEAL}

Os camundongos foram infectados por injeção i.t.com $50 \mu 1$ de uma suspensão de $1 \times 10^{6}$ leveduras viáveis de $P$. brasiliensis. O procedimento de injeção foi realizado com os animais sob anestesia (Cano et al., 1995). 
Primeiro foi administrado uma solução composta de $4 \mathrm{~mL}$ de PSB estéril, $0,5 \mathrm{~mL}$ de ROMPUN - um sedativo, analgésico e relaxante muscular - (Bayer do Brasil) e 0,5 mL de DOPALEN - um analgésico de uso geral, injetável a base de ketamina - (Vetbrands). Quando o animal estava insensível à dor (após 5 minutos), foi feita uma pequena incisão longitudinal na pele do pescoço e a traquéia exposta. O fungo foi administrado em um volume total de $50 \mu 1$. Após a inoculação, a incisão foi suturada e os animais colocados sob uma fonte moderada de calor para controlar a hipotermia transitória produzida pela anestesia, até acordarem (Cano, 1995).

Os animais foram avaliados quanto a vários parâmetros imunológicos após 72 horas, 2 e 10 semanas de infecção.

\subsection{INFECÇÃO SUBCUTÂNEA}

Para realizarmos o experimento de imunoproteção com os animais machos de ambas as linhagens, uma suspensão de células de fungo foi preparada e $5 \times 10^{6}$ leveduras foram injetadas pela via subcutânea (s.c.). Após um período de 15 dias, os animais foram submetidos à infecção i.t. (conforme descrito acima) e avaliados 8 semanas pós-infecção quanto a diversos parâmetros imunológicos (UFC, citocinas, anticorpos).

\subsection{DETERMINAÇÃO DAS UNIDADES FORMADORAS DE COLÔNIA (UFC)}

O grau de infecção foi avaliado em todos os animais através da recuperação de fungos viáveis do pulmão, fígado e baço após 72 horas, 2 e 10 de infecção i.t. Os animais foram sacrificados e um dos pulmões, um lóbulo do fígado e uma parte do baço foram separados, pesados e macerados em $5 \mathrm{ml}$ de PBS com o uso de homogenizadores. Após a maceração os órgãos foram submetidos à centrifugação e o sedimento final foi ressuspendido em um volume de $1 \mathrm{ml}$ de PBS. 
Uma alíquota de $100 \mu 1$ dessa suspensão e de suas diluições (25 e 50 vezes) foram semeadas em placas de Petri com meio de cultura, constituído de BHI-ágar suplementado com $5 \%$ de fator de crescimento de fungo (Restrepo \& Jimenez, 1980; Singer-Vermes et al., 1992) e 4\% de soro equino, conforme preconizado por Castañeda et al. (1988). As placas foram incubadas a $35^{\circ} \mathrm{C}$ e o crescimento das colônias de P. brasiliensis foi acompanhado e registrado diariamente por um período de 15 dias. Os outros fragmentos dos pulmões, fígado e baço foram reservados para estudos histopatológicos.

\subsection{DETERMINAÇÃO DO NÍVEL DOS ANTICORPOS ESPECÍFICOS}

Para determinar a resposta imune humoral dos animais machos infectados i.t. com leveduras viáveis de Paracoccidioides brasiliensis, amostras de sangue foram obtidas de ambas as linhagens de animais nos períodos de 2 e 10 semanas de infecção.

Os anticorpos totais específicos anti- P. brasiliensis e os seus isótipos $\operatorname{IgM}, \operatorname{IgA}, \operatorname{IgG} 1$, IgG2a, IgG2b e IgG3 foram quantificados pelo método imunoenzimático (ELISA) previamente padronizado para esse sistema antígeno-anticorpo por Mendes-Giannini et al. (1984) e modificado por Vaz et al. (1998).

\subsubsection{ANTÍGENO}

O antígeno utilizado foi do tipo solúvel, CFA (Cell-Free-Antigen) descrito por Camargo et al. (1991), constituído da mistura de antígenos individuais obtidos de 6 isolados distintos do $P$. brasiliensis ( $\mathrm{Pb}$ 339, Pb 265, Pb 18 REI, Pb 18 BIREI e Pb18 TRIREI). Para a obtenção do antígeno, as células foram lavadas em tampão fosfato $0,1 \mathrm{M}, \mathrm{pH} 7,2$. 


\subsubsection{ANTI-SOROS}

Foram utilizados anti-soros não marcados contra imunoglobulinas murinas produzidos em cabra (anti-Ig total, anti-IgM, anti-IgA, anti-IgG1, anti-IgG2a, anti-IgG2b, anti-IgG3) e anti-IgG de cabra marcado com peroxidade (Shouthern Biotecnologies).

Cada anti-soro foi utilizado de acordo com titulação previamente padronizada em nosso laboratório.

\subsubsection{ENSAIO IMUNOENZIMÁTICO}

O ensaio consiste na sensibilização de microplacas de 96 poços de fundo chato (COSTAR) com $100 \mu \mathrm{L}$ do antígeno CFA diluído em tampão carbonato-bicarbonato (TCB) 0,1 M pH 9,5 por poço para uma concentração de 39,3 $\mu \mathrm{g} / \mathrm{mL}$ de proteína $(3,93 \mu \mathrm{g} /$ poço). As placas foram incubadas por uma hora à $37^{\circ} \mathrm{C}$ e mantidas overnight à $4^{\circ} \mathrm{C}$.

Após a incubação foram feitas 5 lavagens com $200 \mu \mathrm{L}$ /poço com uma solução de PBS contendo Tween 20 a $0,05 \%$, processo este repetido a cada etapa. Os sítios livres foram bloqueados com $200 \mu \mathrm{L}$ de gelatina a $0,5 \%$ em TCB e as placas foram novamente incubadas à $37^{\circ} \mathrm{C}$ por 1hora. Os controles positivos e negativos e as amostras foram adicionados à placa em diluições iniciais de 1/40 em PBS/T20 e diluídas seqüencialmente na base 2 em volume de $100 \mu \mathrm{L}$ e incubadas por 1 hora à $37^{\circ} \mathrm{C}$. Após a lavagem das placas foram adicionados os antisoros marcados em diluições adequadas determinadas por titulações prévias e novamente as placas foram mantidas sob incubação por 1 hora à $37^{\circ} \mathrm{C}$.

Depois de nova lavagem o anti-soro conjugado a peroxidade foi adicionado à placa e incubado. A reação com o substrato foi realizada com a adição de $25 \mathrm{ml}$ de tampão citrato de sódio a $0,1 \mathrm{M}, \mathrm{pH} 5,0$ na presença de OPD (10 mg de ortofenilenodiamina) e $10 \mu \mathrm{L}$ de $\mathrm{H}_{2} \mathrm{O}_{2}$ a $30 \%$ em temperatura ambiente e colocado ao abrigo da luz por 15 minutos. 
A reação enzimática foi interrompida pela adição de $50 \mu \mathrm{L}$ ácido sulfúrico $4,0 \mathrm{~N}$. A leitura das placas foi realizada em leitor automático no comprimento de onda de $490 \mathrm{~nm}$. O cutoff da reação foi determinado em cada placa, pela média das densidades ópticas (DO) obtidas através de um pool de soros negativos (controle) dosados em quadruplicata.

As DO de cada diluição dos soros experimentais foram comparadas frente ao respectivo cut-off, determinando assim que o título de cada amostra fosse expresso como a recíproca da maior diluição do soro experimental apresentando DO superior à leitura do soro negativo.

\subsection{DETERMINAÇÃO DOS NÍVEIS DE CITOCINAS}

\subsubsection{OBTENÇÃO DOS HOMOGENATOS DOS PULMÕES, FÍGADO E BAÇO}

As citocinas foram dosadas a partir do homogenato obtido do macerado dos órgãos utilizados na determinação de UFC nos diferentes tempos de infecção. Os sobrenadantes foram aliquotados e mantidos a $-70^{\circ} \mathrm{C}$ até o momento da dosagem das citocinas.

\subsubsection{CARACTERIZAÇÃO DAS CITOCINAS: ELISA PARA QUANTIFICAÇÃO DE IL- 2, IL-4, IL-5, IL-10, IL-12, TNF- $\alpha$, IFN- $\gamma$, TGF- $\beta$, MCP-1 e GM-CSF.}

A presença das citocinas, quimiocina e fator de crescimento foras analisadas pelo método de ELISA de captura utilizando-se pares de anticorpos monoclonais (AcM) para cada citocina murina (Pharmingen). 


\subsubsection{DOSAGEM DAS CITOCINAS}

A presença e concentração das citocinas foram determinadas pelo teste de ELISA de captura, de acordo com a metodologia descrita para o nosso modelo (Cano et al, 1998, 2000). Os ensaios foram baseados na utilização de pares de anticorpos monoclonais (AcM) específicos para cada tipo de citocina, um dos quais marcado com biotina.

O emprego dos complexos biotina-avidina e peróxido de hidrogênio-peroxidase permite a determinação da concentração da citocina presente por medidas de densidade óptica. Os procedimentos seguidos foram recomendados pelo fabricante do kit utilizado (BD, Pharmingen).

A técnica consiste em sensibilizar os 96 wells da placa de poliestireno com $50 \mu \mathrm{L}$ de AcM primário na concentração determinada diluído em solução de bicarbonato de sódio $0,1 \mathrm{M}, \mathrm{pH} 5,0$. As placas foram incubadas por 24 horas a $4^{\circ} \mathrm{C}$. No dia seguinte, as placas foram submetidas a lavagem (tampão PBS pH 7,0 e Tween 20 a 0,05\% ) e os sítios livres foram bloqueados com $200 \mu \mathrm{L}$ por poço com gelatina (Difco) a $1 \%$ (m/v) diluído em PBS isotônico pH 7,0, por duas horas à temperatura ambiente. Após este período, as placas foram novamente lavadas e as citocinas recombinantes (Pharminger) diluídas em PBS isotônico com 10\% de soro bovino fetal (SBF) foram adicionadas procedendo-se à sua diluição seriada para obtenção das curvas-padrão. $\mathrm{Na}$ mesma etapa adicionavam-se as amostras e procedia-se à incubação a $4^{\circ} \mathrm{C}$ por um tempo determinado de acordo com cada kit.

Depois desta incubação e de nova lavagem foi adicionado $50 \mu \mathrm{L}$ do AcM secundário biotinilado na concentração desejada, diluído em meio PBS isotônico com 10\% de SBF e a placa foi novamente incubada a temperatura ambiente por 45 minutos. A revelação foi feita após nova lavagem e a adição de $50 \mu \mathrm{L}$ do complexo biotina-estreptavidina-peroxidase diluído em PBS e 0,1\% de Tween 20 (Sigma) e após a incubação determinada por cada kit, foi realizada nova lavagem para então acrescentar $50 \mu \mathrm{L}$ do substrato contendo $5 \mathrm{~mL}$ de $\mathrm{H}_{2} \mathrm{O}_{2}$ a $30 \%$ (Merck) diluídos em solução composta por $2,8 \mathrm{~mL}$ de tampão fosfato de sódio $0,2 \mathrm{M}, 2,2 \mathrm{~mL}$ de ácido cítrico 0,1 M (pH 5,0) e $10 \mathrm{~mL}$ de $\mathrm{H}_{2} \mathrm{O}$, adicionado de $10 \mathrm{mg}$ de ortofenilenodimina (OPD) (Merck). A placa foi encubada por 45 minutos a temperatura ambiente e protegida da luz. A reação enzimática foi parada pela adição de $50 \mu \mathrm{L}$ de ácido sulfúrico $4 \mathrm{~N}$. 
A leitura das densidades ópticas foi então realizada em leitor automático (VERSAmax Molecular Devices Corporation) em comprimento de onda de $492 \mathrm{~nm}$. e as concentrações das citocinas foram determinadas tendo como base a reta de regressão linear obtida com os dados referentes às diluições das citocinas recombinantes (curva - padrão).

\subsection{CARACTERIZAÇÃO DO GENE DE CD28 POR PCR EM DNA GENÔMICO DE CAMUNDONGOS NORMAIS E DEFICIENTES PARA ESTA MOLÉCULA}

A análise do DNA genômico dos camundongos normais e CD28-deficientes da linhagem C57Bl/6 foi realizada pela Dra. Silvia Massironi do Departamento de Imunologia do ICB-IV da USP.

O DNA genômico foi extraído através de técnicas padrão a partir de fragmento de cauda. A concentração do DNA foi acertada para $30 \mathrm{ng} / \mathrm{ml}$. A partir destas soluções foi realizada uma PCR (Reação de Polimerase em Cadeia) para evidenciar os fragmentos gênicos característicos de animais $\mathrm{C} 57 \mathrm{Bl} / 6 \mathrm{CD} 28 \mathrm{KO}$ e $\mathrm{C} 57 \mathrm{Bl} / 6$ selvagens. Os reagentes utilizados nesta reação foram: tampão PCR 10 x concentrado, solução de $\mathrm{Mg}^{++}$, dnTP, Taq polimerase e "primers" específicos (591, 592 e 593) seguindo especificações da Jackson Laboratory. Todos os reagentes adicionados e as amostras foram levadas ao termociclador sendo submetidos a 35 ciclos de 6 fases com temperaturas variando de $4^{\circ} \mathrm{C}$ a $75^{\circ} \mathrm{C}$ e tempo que variava entre 30 segundos e 2 minutos cada fase. Os produtos da PCR foram submetidos então a uma eletroforese em gel de agarose a $1 \% \mathrm{em}$ presença de brometo de etídio. A identificação dos animais C57Bl/6 selvangens deu-se pela presença de uma banda de 600pb (pares de base) gerada pelos primers 591 (CTG CTT GTG GTA GAT AGC AAC GA) e 592 (CCT GAG TCC TGA TCT GTC AGA CT). Por outro lado, os animais $\mathrm{C} 57 \mathrm{Bl} / 6 \mathrm{CD} 28 \mathrm{KO}$ foram identificados por uma banda de 740pb gerada pelos primers 592 e 593 (ATT CGG CAA TGA CAA GAC GTT GG). 


\subsection{DOSAGEM DE NO}

A concentração de óxido nítrico no sobrenadante dos pulmões e fígado nos tempos de 72 horas, 2 e 10 semanas de infecção nos animais machos foi medida com o reagente de Griess (1\% sulfanilamida, $0,1 \%$ diidrocloreto de naftiletilenodiamina, 2,5\% $\left.\mathrm{H}_{3} \mathrm{PO}_{4}\right)$, sendo utilizado um volume de $50 \mu \mathrm{L}$ do sobrenadante e igual volume do reagente de Griess.

Foram incubados em temperatura ambiente por 15 minutos e então determinada a absorbância em equipamento Labsystems Multiskan MCC/340 (leitor). A concentração de óxido nítrico foi determinada utilizando-se curva padrão padronizada com diferentes concentrações de nitrito de sódio (Ding et al.,1988).

\subsection{DETERMINAÇÃO DO TEMPO MÉDIO DE SOBREVIDA}

Grupos de 8-10 camundongos CD28KO e seus controles foram infectados com 1x10 células leveduriformes pela via i.t. e a mortalidade destes foi acompanhada diariamente.

\subsection{ANÁLISE HISTOPATOLÓGICA DOS PULMÕES}

Foi examinado um dos pulmões de cada um dos animais utilizados na determinação de UFC nos tempos de 2 e 10 semanas pós-infecção. Os órgãos foram preservados em solução de Millonig modificada (Carson et al., 1973) à temperatura ambiente até o momento do processamento. Posteriormente, já incluídos em parafina, foram cortados fragmentos na espessura de 4 a $5 \mu \mathrm{m}$ e submetidos à coloração por hematoxilina-eosina (H\&E) para identificação celular.

O preparo das lâminas foi feito pelo Setor de Histologia do Departamento de Imunologia do ICB IV- USP e a análise descritiva das lesões foi realizada ao microscópio óptico comum pela Profa. Dra. Vera Luiza Capelozzi, do Departamento de Anatomia Patológica da Faculdade de Medicina da Universidade de São Paulo. 
MATERIAL E MÉTODOS

\subsection{ANÁLISE ESTATÍSTICA DOS DADOS}

Nos experimentos de UFC, NO e citocinas, os grupos de animais infectados com $P$. brasiliensis foram analisados pelo test T-Student, método não pareado, (Graphpad-PrismSoftware version 2.01).

Os experimentos com mais de 2 amostras foram analisados por ANOVA seguido de múltiplas comparações de acordo com Tukey.

Resultados onde $\mathrm{p}<0,05$ foram considerados significantes. 
RESULTADOS 


\subsection{CARACTERIZAÇÃO DO GENE DE CD28 POR PCR EM DNA GENÔMICO DE CAMUNDONGOS NORMAIS E DEFICIENTES PARA ESTA MOLÉCULA}

Os resultados apresentados na figura 1 referem-se à aná0lise eletroforética de material obtido de um dos experimentos realizados para confirmação do patrimônio genético dos animais. Camundongos que apresentam a banda em torno de 600pb correspondem ao padrão selvagem, enquanto que a revelação de banda em torno de 740 pb correspondem ao genótipo CD28KO. A expressão de ambas as bandas ocorre em animais heterozigotos. As reações para amplificações dos genótipos WT e KO foram feitas em tubos separados e revelados em fileira independente do gel de agarose.

A figura 1 mostra o resultado de um experimento com 4 camundongos: o camundongo 1 apresenta as 2 bandas (600 e 740pb), portanto um camundongo heterozigoto; o camundongo 2 apresenta a banda de 740pb e é, então, um camundongo CD28KO; o camundongo 3 apresenta as 2 bandas, e é heterozigoto enquanto que o camundongo 4 apresenta somente a banda de $600 \mathrm{pb}$ sendo então do genótipo selvagem.

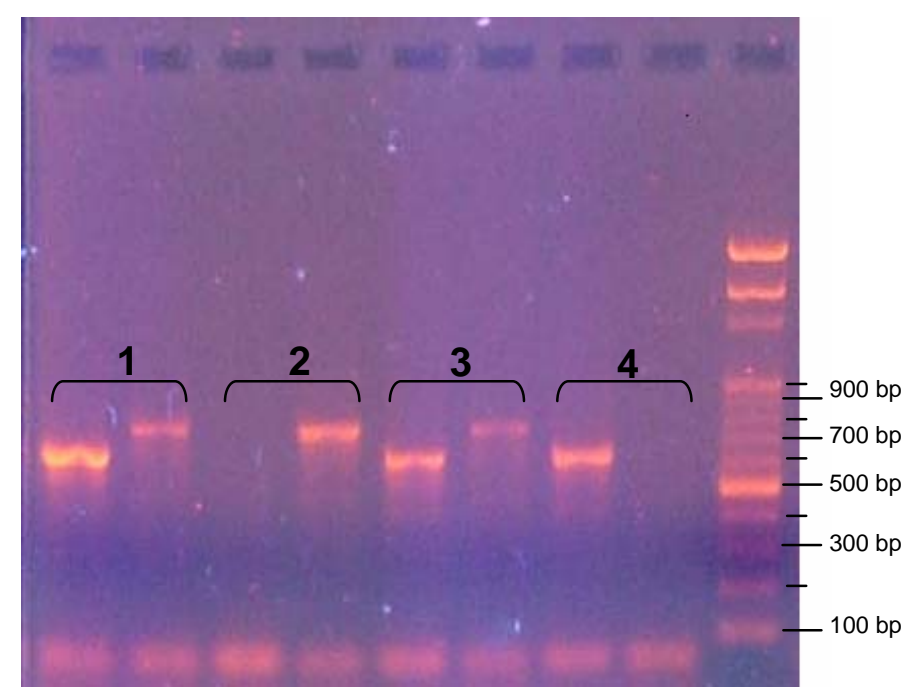

Figura 1: Fotografia do gel da PCR para caracterização dos genótipos dos camundongos C57B1/6 selvagens (WT) e C57B1/6 CD28KO (KO). 


\subsection{AVALIAÇÃO DO GRAU DE INFECÇÃO PELA DETERMINAÇÃO DE UNIDADES FORMADORAS DE COLÔNIAS (UFC).}

Os resultados apresentados a seguir foram obtidos de experimentos realizados através da inoculação de $1 \times 10^{6}$ leveduras viáveis de $P$. brasiliensis por via i.t. e pela determinação de UFC nos tempos de 72 horas, 2 e 10 semanas de infecção em animais machos. Todos os experimentos foram repetidos por três vezes.

Grupos de animais machos CD28KO e controle normais da linhagem C57B1/6 foram inoculados e sacrificados após os tempos acima especificados. Um dos pulmões, um lóbulo do fígado e parte do baço foram removidos, pesados, macerados e plaqueados em ágar BHI suplementado. O número de colônias foi contado durante 15 dias e o número final transformado em $\log _{10} / g$ de tecido.

$\mathrm{Na}$ figura-2 A pode-se verificar que após 72 horas de infecção os animais machos CD28KO $\left(4,13 \pm 0,31 \log _{10}\right)$ apresentaram carga fúngica pulmonar praticamente igual àquela observada nos animais controle $\left(4,21 \pm 0,20 \log _{10}\right)$ não ocorrendo disseminação para o fígado (figura 1B).

Os resultados obtidos após 2 semanas de infecção com os dois grupos de animais demonstraram que os animais $\mathrm{CD} 28 \mathrm{KO}\left(4,9 \pm 0,04 \log _{10}\right)$ apresentaram carga fúngica maior que aquela observada nos animais controle $\left(4,2 \pm 0,07 \log _{10}\right)$, sendo esta diferença estatisticamente significante (figura 2A). Por outro lado, não foram observadas diferenças estatisticamente significantes entre os números de fungos viáveis no fígado de animais de ambos os grupos (figura 2B). 
RESULTADOS

No período de 10 semanas de infecção, os pulmões dos animais CD28KO $(6,10 \pm 0,04$ $\log _{10}$ ) apresentaram um aumento significante da carga fúngica quando comparados aos dos animais controle $\left(4,20 \pm 0,20 \log _{10}\right)$. Da mesma maneira, o fígado dos animais CD28KO $(3,00 \pm$ $\left.0,28 \log _{10}\right)$ apresentava aumento significante da carga fúngica quando comparada com a dos animais controle $\left(0,01 \pm 0,01 \log _{10}\right)$.

Em ambas as linhagens de animais e em todos os tempos pós-infecção o baço não apresentou diferenças estatisticamente significantes entre animais normais e CD28-deficientes.
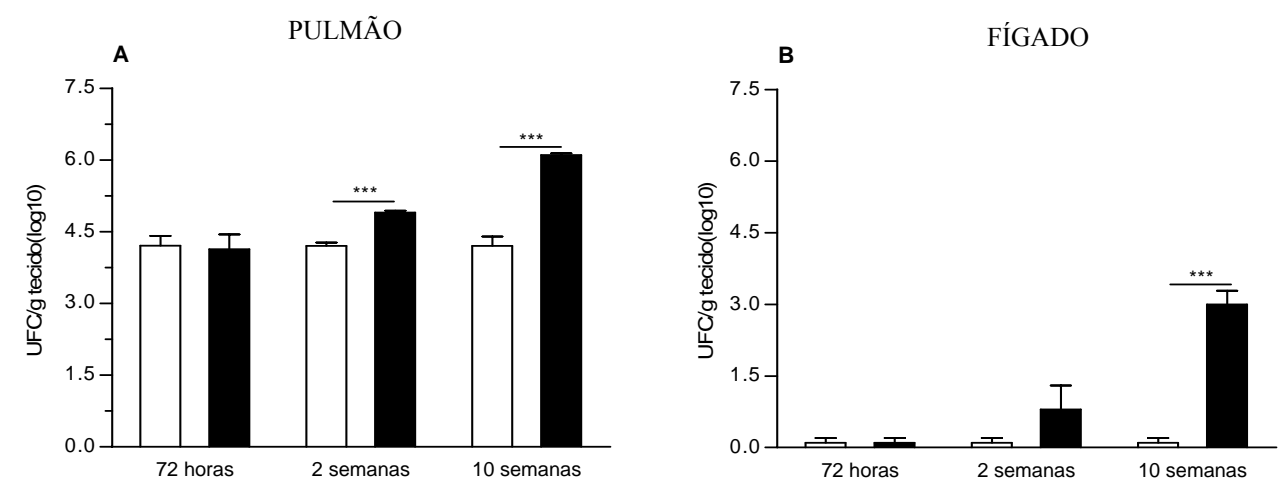

CONTROLE

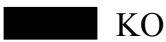

Figura 2. Avaliação da gravidade da doença por contagem do número de Unidades Formadoras de Colônias (UFC)/g de tecido $\left(e m \log _{10}\right)$ dos camundongos machos CD28KO $(n=5-7)$ e controle $(n=5-7)$ após 72 horas, 2 e 10 semanas de infecção com $1 \times 10^{6}$ leveduras de P. brasiliensis inoculadas por via i.t. A Pulmões dos animais machos B Fígado dos animais machos. As barras representam as médias \pm EP dos grupos ensaiados.

$* * * \mathrm{p}<0,001$. 


\subsection{DETERMINAÇÃO DO NÍVEL DE ANTICORPOS ANTI- P. BRASILIENSIS.}

A resposta imune humoral desenvolvida pelos dois grupos de animais (CD28KO e controle) foi avaliada através da quantificação de anticorpos específicos pelo método de ELISA. Os soros foram obtidos durante a realização dos experimentos para determinar as UFC. Os animais de ambos os grupos foram anestesiados e através do seccionamento de veias e artérias axilares, foram coletadas amostras de sangue para obtenção do soro. As amostras foram estocadas a $-20^{\circ} \mathrm{C}$ até a realização do ensaio de ELISA.

O soro de cada animal foi analisado quanto aos níveis de imunoglobulina total (IgT) e dos diferentes isótipos específicos (IgM, IgA, IgG1, IgG2a, IgG2b e IgG3). Os resultados foram transformados em unidades logarítmicas na base 2 e expressos como média \pm erro padrão.

Por sabermos que a partir de 2 semanas (aproximadamente 15 dias) a resposta imune humoral começa a ser estabelecida, a quantificação dos isótipos específicos foi realizada nos tempos de 2 e 10 semanas de infecção.

Os grupos de animais foram analisados pelo teste t-de Student não pareado (GraphpadPrism Software version 4) e os resultados onde $P<0,05$ foram considerados significantes.

A figura 3 apresenta os resultados obtidos na segunda e na décima semana de infecção. Como pode ser verificado, na segunda semana o nível de anticorpos específicos não apresentou diferença estatística para quase todos os isótipos, exceto para a imunoglobulina da classe IgM em que aparece aumentado nos animais controle $\left(5,32 \pm 0,01 \log _{2}\right)$ quando comparado com o dos animais CD28KO $\left(2,12 \pm 1,30 \log _{2}\right)$. Entretanto, no período de 10 semanas de infecção, os níveis de anticorpos específicos para $P$. brasiliensis foram significativamente maiores nos animais controle do que nos CD28KO. 
Este aumento pôde ser observado nos títulos de Ig total (controle 11,18 $\pm 0,79 \log _{2}$ e CD28KO $2,96 \pm 0,93 \log _{2}$ ), IgG1 (controle $10,90 \pm 0,75 \log _{2}$ e CD28KO 3,55 $\pm 0,89 \log _{2}$ ), IgG2a (controle 6,75 $\pm 0,48 \log _{2}$ e CD28KO 0,59 $\pm 0,59 \log _{2}$ ) e IgG2b (controle 10,61 $\pm 0,86 \log _{2}$ e CD28KO 5,99 $\pm 0,17 \log _{2}$ ), onde são significativamente maiores nos animais controle.

Neste período, não foram observadas diferenças estatisticamente significativas nos títulos de IgM, IgA e IgG3.
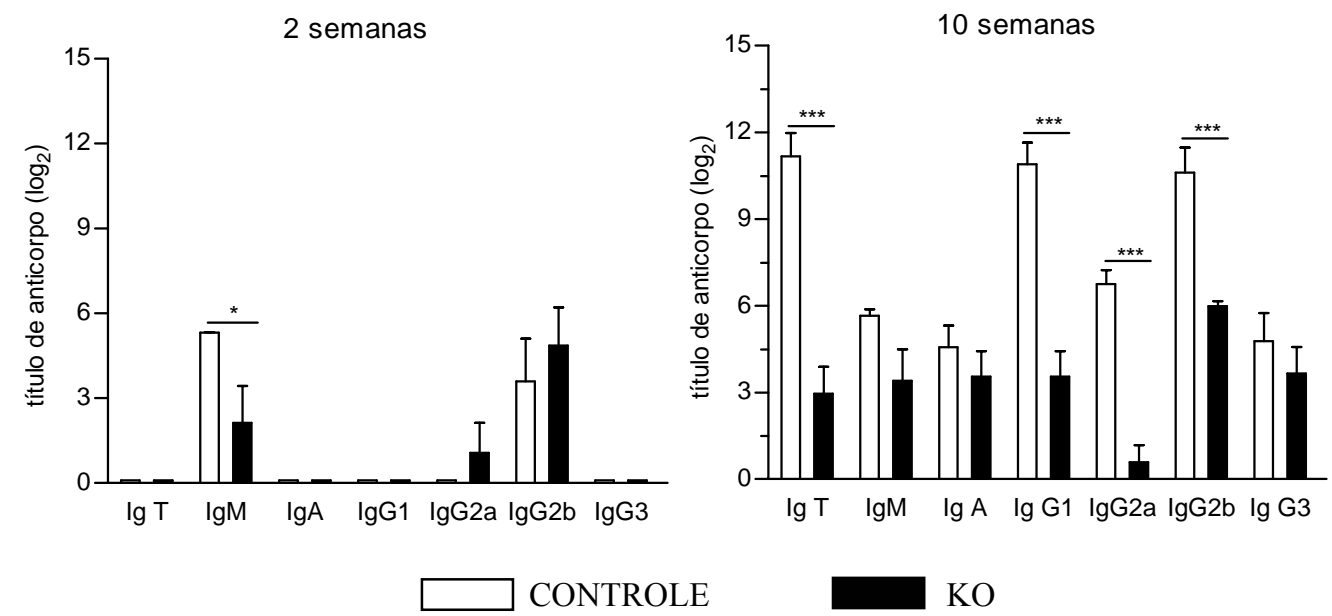

Figura 3: Quantificação dos isótipos de anticorpos específicos anti P. brasiliensis presentes no soro de animais machos CD28KO e controle após 2 e 10 semanas de infecção com 1x10 leveduras de P. brasiliensis pela via i.t.

$* \mathrm{p}<0,05 * * * \mathrm{p}<0,001$

\subsection{QUANTIFICAÇÃO DE CITOCINAS}

Os níveis de citocinas produzidos pelos animais CD28KO e controle (WT) foram quantificados no sobrenadante de pulmão e fígado após os períodos de 72 horas, 2 e 10 semanas de infecção. Os dados estão apresentados sob a forma de gráfico para facilitar a visualização dos mesmos e sob a forma de tabela (em anexo) para que não se percam os detalhes numéricos das quantificações. 


\subsubsection{CITOCINAS DO TIPO 1 EM PULMÃO E FÍGADO DOS CAMUNDONGOS MACHOS CD28KO E CONTROLE}

Na figura 4 (e anexo 1) estão mostrados os resultados obtidos para as citocinas tipo 1 no sobrenadante de pulmão e fígado (Média +/- Erro Padrão) nos tempos de 72 horas, 2 e 10 semanas após a infecção com o fungo $P$. brasiliensis em animais normais e CD28-deficientes.

No período de 72 horas de infecção não observamos diferenças estatisticamente significantes na concentração de citocinas presentes no sobrenadante de pulmão e fígado. Já na segunda semana de infecção observamos diferenças significantes para a IL-2 do fígado, onde os níveis da citocina nos animais controle $(692,0 \pm 99,0)$ eram maiores que os dos animais KO $(269,0 \pm 110,0)$.

Entretanto, no período de 10 semanas de infecção a citocina IL-12 apresentou-se significantemente aumentada nos pulmões de animais controle $(19168,0 \pm 693,0)$ quando comparado com os animais KO $(14277,0 \pm 195,0)$. O mesmo ocorreu com a citocina TNF- $\alpha$ onde os animais controle $(20839,0 \pm 244,0)$ apresentaram aumento significativo quando comparado com os animais $\mathrm{KO}(17716,0 \pm 386,0)$.

No sobrenadante de fígado, os animais controle também apresentaram aumento significante das citocinas quando comparados com os animais KO. Este aumento pôde ser observado para as citocinas IL-12 (controle 20265,0 \pm 0, e CD28KO 18314,0 $\pm 424,0$ ), IFN- $\gamma$ (controle $18608,0 \pm 970,0$ e CD28KO 13869,0 $\pm 1145,0$ ) e TNF- $\alpha$ (controle 26015,0 $\pm 0,1$ e CD28KO 22931,0 $\pm 675,0)$. 
RESULTADOS

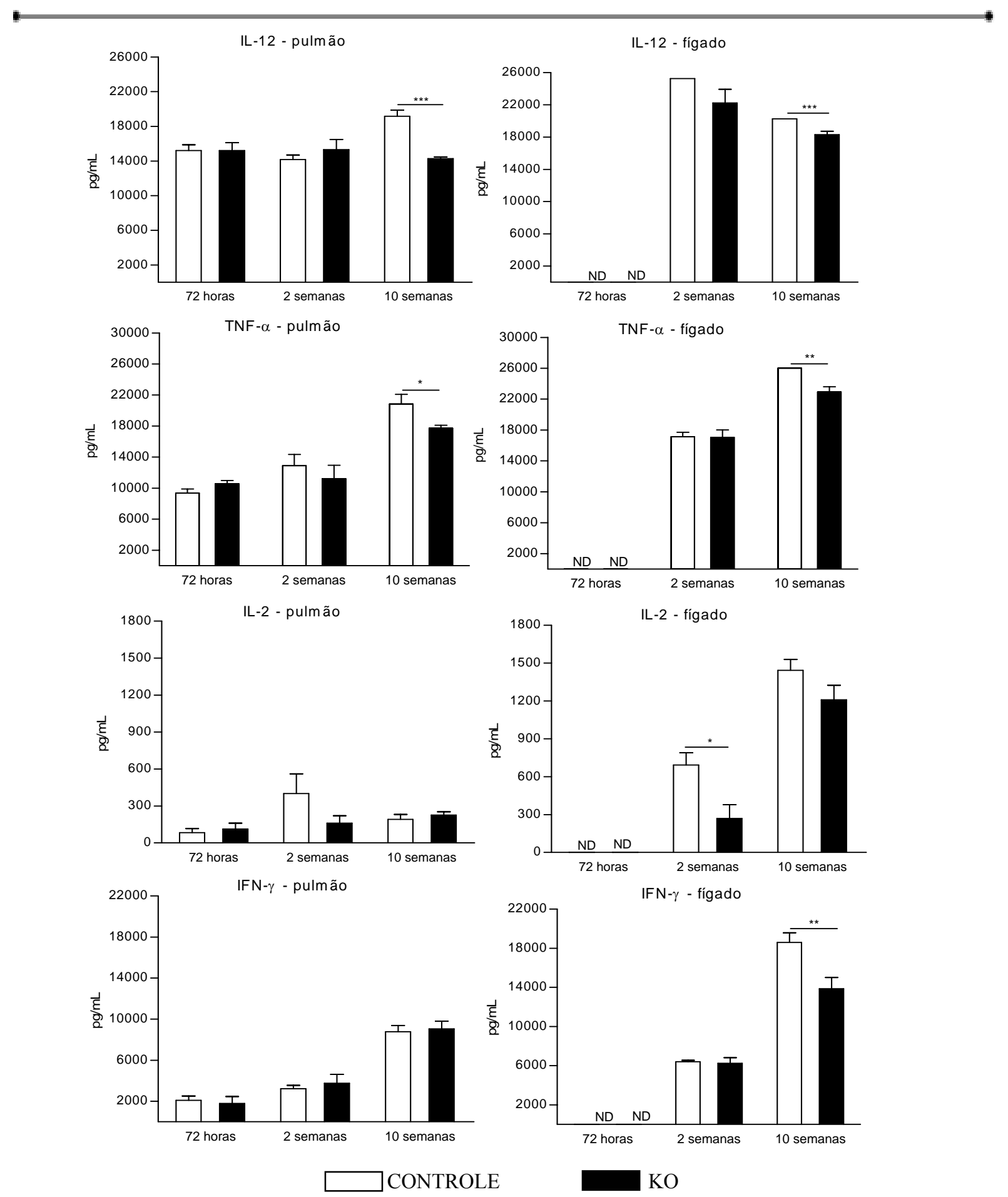

Figura 4: Quantificação de citocinas ( $\mathrm{pg} / \mathrm{mL})$ do tipo 1 nos homogenatos de pulmão e fígado de animais machos C57B1/6 e C57B1/6 CD28KO em vários períodos de infecção i.t. com 1×10 leveduras de P. brasiliensis.

$* \mathrm{p}<0,005 * * \mathrm{p}<0,01 * * * \mathrm{p}<0,001 \mathrm{ND}=$ não dosado 


\subsubsection{CITOCINAS DO TIPO 2 EM PULMÃO E FÍGADO DOS CAMUNDONGOS MACHOS CD28KO E CONTROLE}

As citocinas do tipo 2 foram dosadas em ambos os grupos de animais e os resultados estão apresentados na figura 5 (e anexo 2).

Nas primeiras 72 horas de infecção não observamos diferenças estatisticamente significantes entre os grupos de animais machos estudados. Entretanto, do período de 2 semanas de infecção, os animais controle $(995,0 \pm 146,0)$ apresentaram aumento significante da IL-4 no sobrenadante de fígado quando comparados com os animais CD28 KO $(473,0 \pm 141,0)$. As outras citocinas apresentaram-se em valores semelhantes em ambos os grupos.

Na décima semana de infecção observamos aumento significante da IL-5 no pulmão dos animais CD28 KO $(1237,0 \pm 59,0)$ quando comparado com animais controle $(929,0 \pm 44,0)$. Neste mesmo período de infecção, os animais controle $(8129,0 \pm 387,0)$ apresentaram aumento significante da IL-10 no fígado quando comparados com os animais CD28 KO $(5727,0 \pm 342,0)$. As outras citocinas não apresentaram diferenças estatisticamente significante no tempo de 10 semanas de infecção. 
RESULTADOS
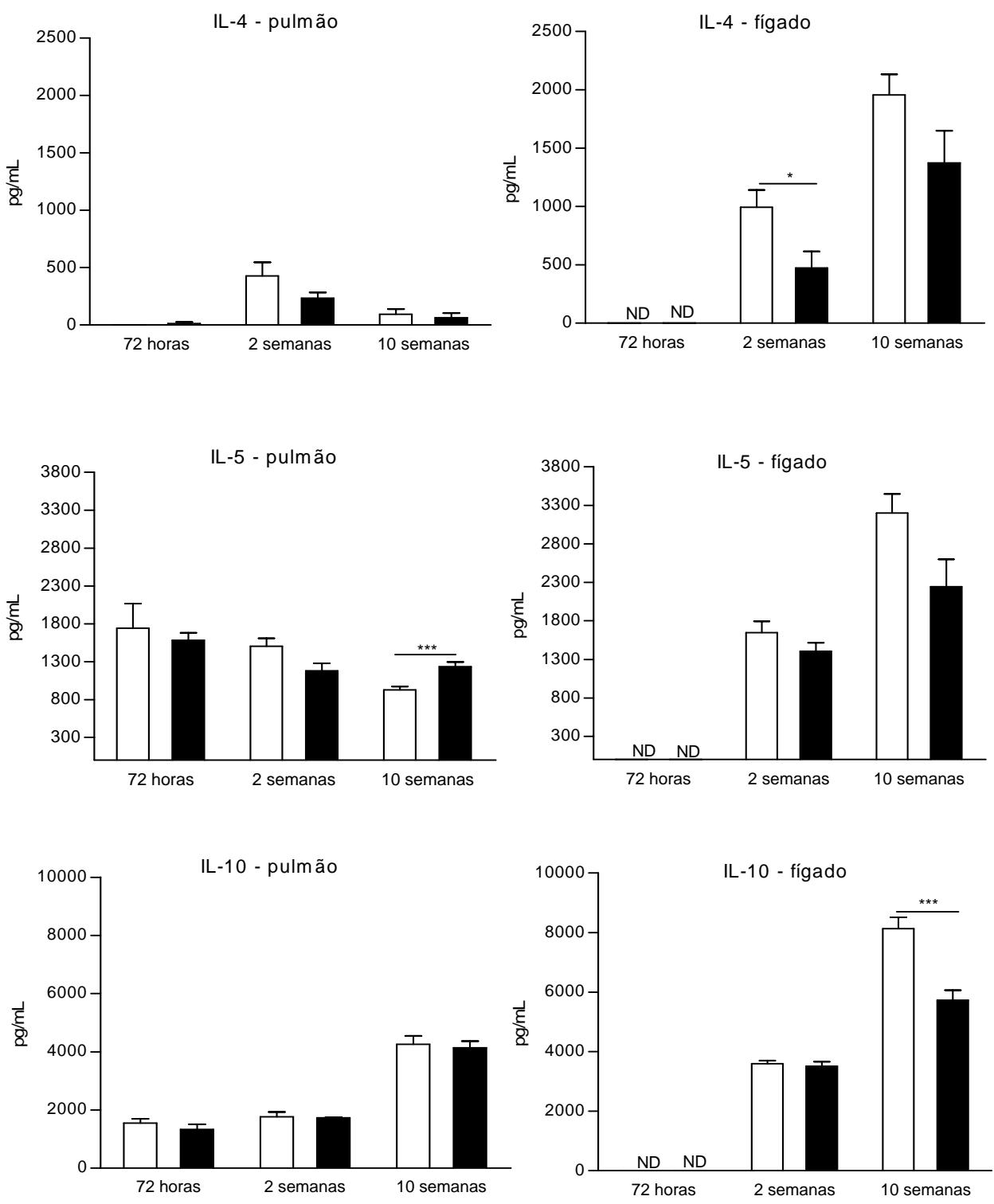

CONTROLE

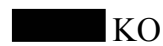

Figura 5: Quantificação de citocinas $(\mathrm{pg} / \mathrm{mL})$ do tipo 2 nos homogenatos de pulmão e fígado de animais machos C57B1/6 e C57B1/6 CD28KO em vários períodos de infecção i.t. com 1×10 leveduras de P. brasiliensis.

$* \mathrm{p}<0,05 * * * \mathrm{p}<0,001 \mathrm{ND}=$ não dosado 
RESULTADOS

\subsubsection{NÍVEIS DO FATOR DE CRESCIMENTO GM-CSF E DA QUIMIOCINA MCP-1 NO PULMÃO E FÍGADO DOS CAMUNDONGOS CD28KO E CONTROLE}

Utilizando o protocolo acima descrito, quantificamos os níveis de GM-CSF e de MCP-1 em todos os períodos pós-infecção conforme mostrado na figura 6 (e anexo 3).

Nos períodos de 72 horas, 2 e 10 semanas de infecção não observamos diferenças estatisticamente significantes entre os níveis de GM-CSF e MCP-1 no pulmão de ambos os grupos de camundongos. Não observamos também diferença estatística entre os grupos para MCP-1 do fígado. Entretanto, na segunda semana de infecção os animais controle $(2433,0 \pm$ 192,0) apresentaram aumento significativo de GM-CSF no fígado quando comparado com os animais $\mathrm{KO}(1423,0 \pm 200,0)$. O mesmo fenômeno pôde ser observado no período de 10 semanas de infecção (controle 4048,0 $\pm 227,0$ x CD28KO 2818,0 \pm 427,0).
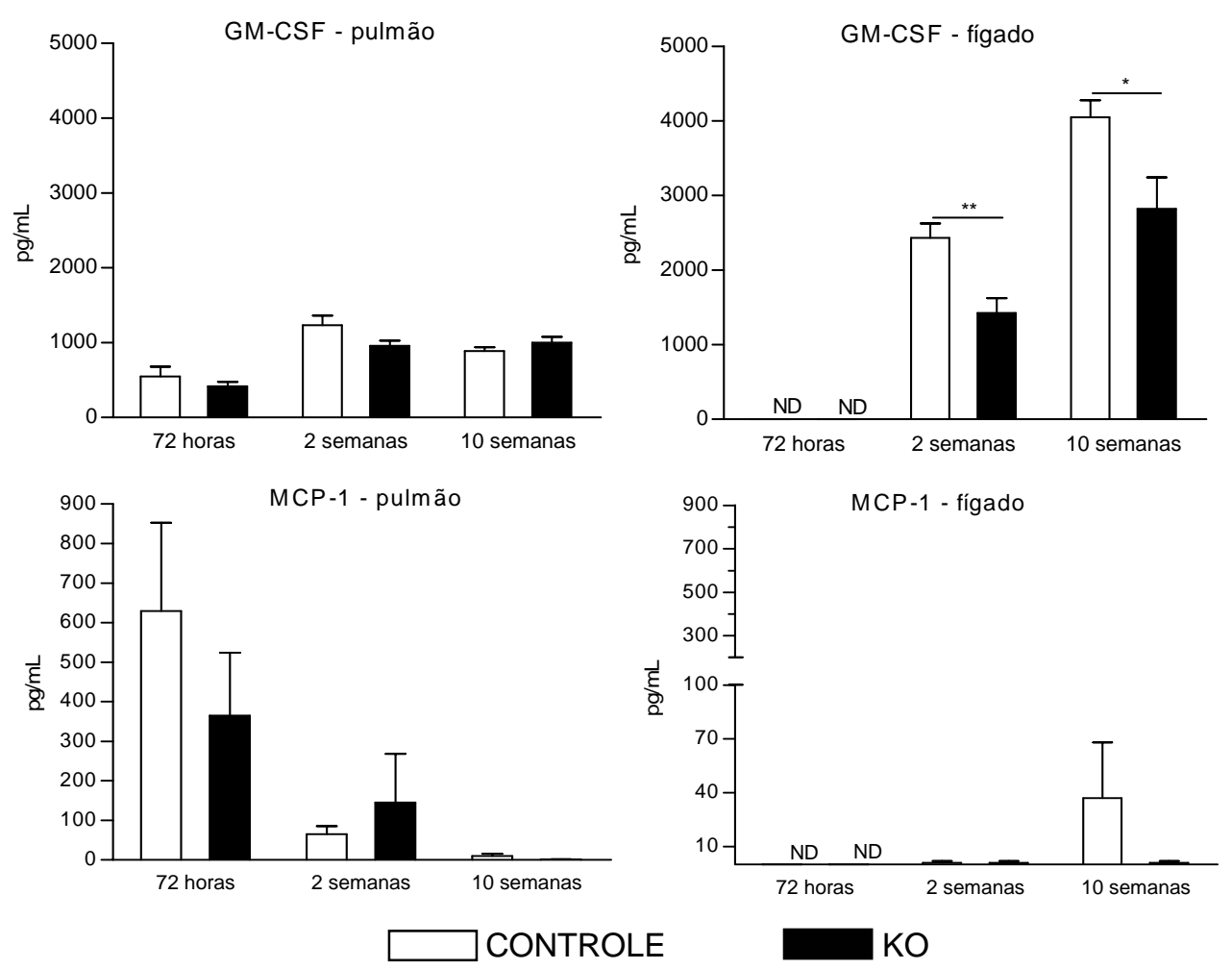

Figura 6: Quantificação do fator de crescimento GM-CSF e da quimiocina MCP-1 (pg/ml) nos homogenatos de pulmão e fígado de animais machos C57B1/6 e C57B1/6 CD28KO em vários períodos de infecção i.t. com $1 \times 10^{6}$ leveduras de $P$. brasiliensis. * $\mathrm{p}<0,05 * * \mathrm{p}<0,01 \mathrm{ND}=$ não dosado 


\subsection{DOSAGEM DE NO}

Os níveis de NO foram quantificados nos sobrenadantes de pulmão e fígado de animais normais e CD28-deficientes em todos os períodos de pós-infecção. Os resultados estão apresentados na figura 7.

No sobrenadante de pulmão dos animais machos não observamos diferenças estatisticamente significantes nos níveis de $\mathrm{NO}$ entre os animais controle e $\mathrm{KO}$, em todos os períodos pós-infecção. Entretanto, níveis mais elevados de $\mathrm{NO}$ foram observados no sobrenadante de fígado de animais machos controle às 72 horas (controle 128,0 $\pm 15,0 \mathrm{x}$ CD28KO 59,6 $\pm 10,5$ ) e 10 semanas (controle 128,2 $\pm 22,9$ x CD28KO 69,2 $\pm 3,3$ ).
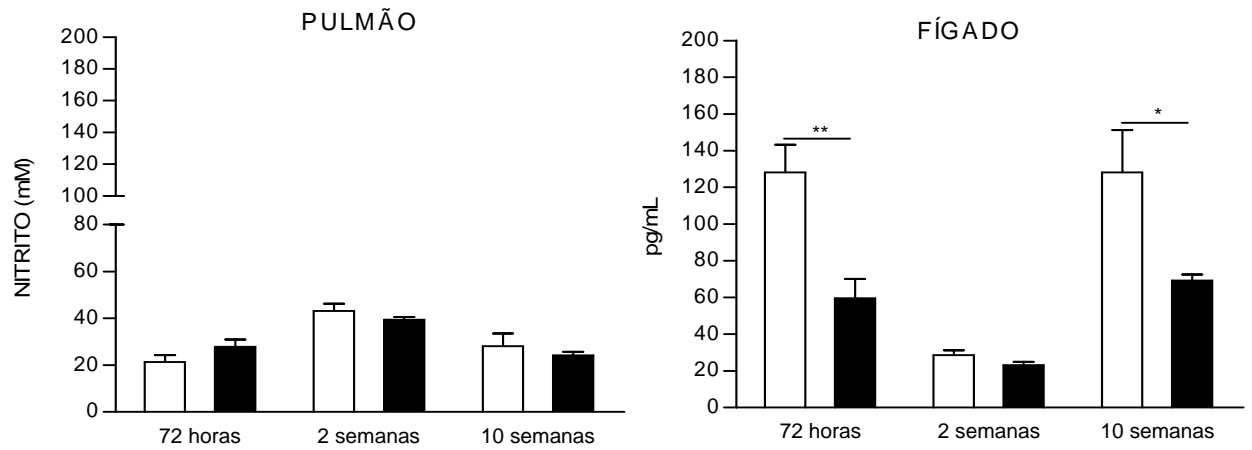

CONTROLE

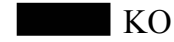

Figura 7: Quantificação de NO no sobrenadante de pulmão e fígado de animais machos após 72 horas, 2 e 10 semanas de infecção com $1 \times 10^{6}$ leveduras de $P$. brasiliensis pela via i.t. Os dados representam a média $+/-$ erro padrão de 4 poços por grupo. $\mathrm{O}$ asterisco representa diferença estatisticamente significante.

$* \mathrm{p}<0,05 * * \mathrm{p}<0,01 * * * \mathrm{p}<0,001$ 


\subsection{TEMPO DE SOBREVIDA}

Grupos de animais C57B1/6 (controle - WT) e C57B1/6 CD28KO foram infectados com leveduras viáveis do $P$. brasiliensis e observados durante um período de 365 dias, sendo registrado o tempo de sobrevida (em dias) para cada animal, conforme mostrado na figura 8.

Como observado na figura 8 , a mortalidade dos animais controle inicia-se no dia 103 e após 365 dias 4 animais continuavam vivos, enquanto que não foram registradas mortes de animais KO durante os 365 de observação.

A análise estatística destes dados de sobrevida (método de comparação de curvas de sobrevida pelo teste de LogRank) demonstrou haver diferença estatisticamente significante entre os grupos de animais WT e KO

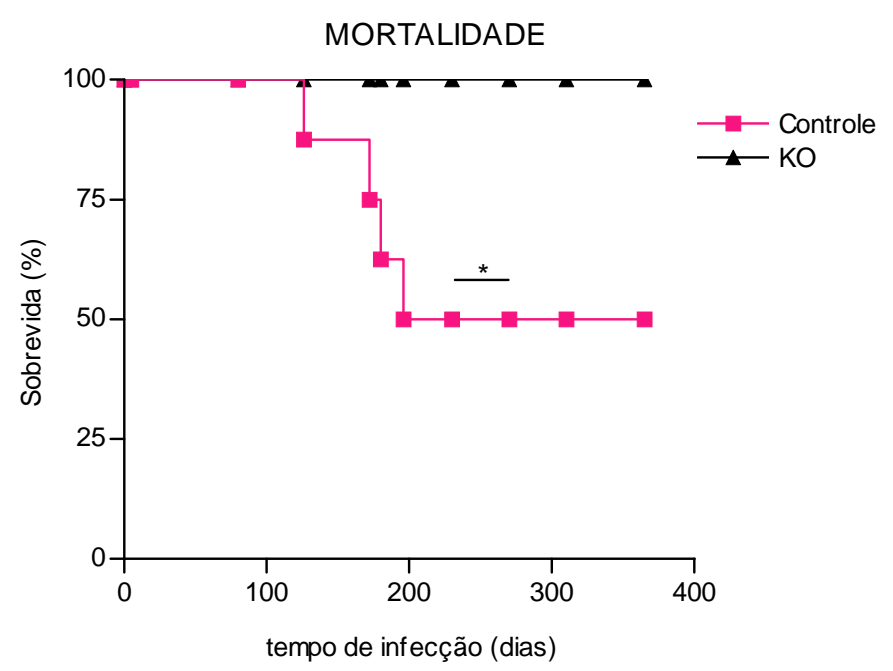

Figura 8: Tempo de sobrevida de camundongos machos C57Bl/6 e C57Bl/6 CD28KO infectados pela via i.t. com $1 \times 10^{6}$ leveduras viáveis do $P$. brasiliensis $(\mathrm{n}=8)$. A sobrevida dos animais foi acompanhada por 365 dias. * $\mathrm{p}<0,05$. Num segundo experimento $(n=8)$ foi observado resultado equivalente. ${ }^{*} \mathrm{p}<0,05$ 
RESULTADOS

\subsection{AVALIAÇÃO DO GRAU DE INFECÇÃO PELA DETERMINAÇÃO DE UNIDADES FORMADORAS DE COLÔNIAS (UFC) DOS ANIMAIS SOBREVIVENTES DO EXPERIMENTO DE MORTALIDADE}

Aos 365 dias de infecção do experimento de mortalidade, sacrificamos os animais sobreviventes e analisamos os órgãos quanto ao número de fungos viáveis. Os resultados estão apresentados na figura 9 .

Observamos grande carga fúngica no pulmão de animais $\operatorname{CD} 28 \mathrm{KO}(4,8 \pm 0,1)$ e número muito pequeno em animais normais $(0,1 \pm 0,1)$. O mesmo comportamento pôde ser observado no fígado onde os animais $\mathrm{KO}(2,2 \pm 0,4)$ apresentaram maior carga fúngica que os animais controle $(0,1 \pm 0,1)$. Ambos os resultados foram estatisticamente significantes.

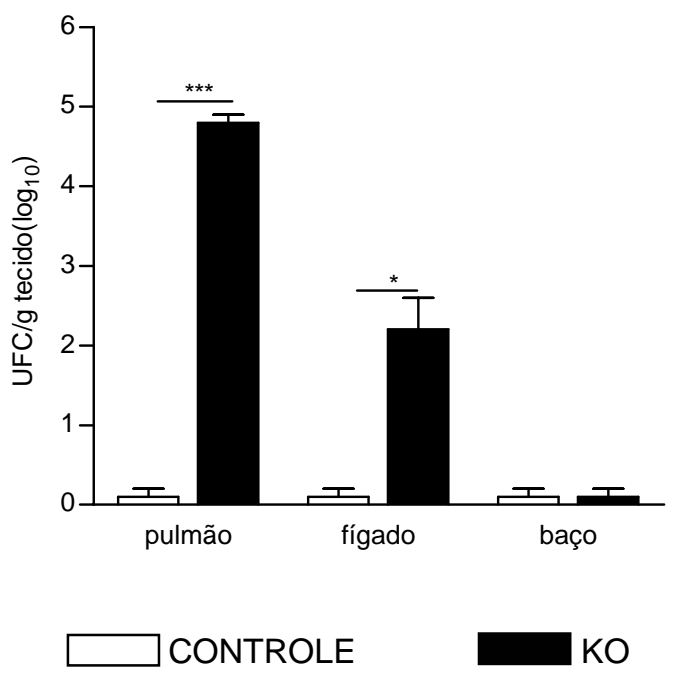

Figura 9. Avaliação da gravidade da doença por contagem do número de Unidades Formadoras de Colônias (UFC)/g de tecido (em $\left.\log _{10}\right)$ dos camundongos machos CD28KO $(n=8)$ e controle $(n=4)$ sobreviventes do experimento de mortalidade após os 365 dias de infecção com $1 \times 10^{6}$ leveduras de $P$. brasiliensis inoculadas por via i.t.

$* \mathrm{p}<0,05 * * * \mathrm{p}<0,001$. 
RESULTADOS

4.8 DETERMINAÇÃO DO NÍVEL DE ANTICORPOS ANTI-P. BRASILIENSIS NOS ANIMAIS SOBREVIVENTES DO EXPERIMENTO DE MORTALIDADE

A resposta imune humoral desenvolvida pelos animais machos sobreviventes do experimento de mortalidade foi avaliada através da quantificação de anticorpos específicos pelo método de ELISA. Os soros foram obtidos durante a realização do experimento de UFC. O soro de cada animal foi analisado quanto aos níveis de imunoglobulina total e dos diferentes isótipos específicos. Os resultados foram transformados em unidades logarítmicas na base 2 e expressos com média \pm erro padrão.

Como pode ser verificado na figura 10, não foram observadas diferenças significantes para a maioria dos isótipos estudados. Pudemos apenas observar aumento de Ig total $(6,32 \pm 0,01$ $\left.\log _{2}\right)$ e $\operatorname{IgG} 2 \mathrm{~b}\left(7,32 \pm 0,01 \log _{2}\right)$ nos animais controle quando comparados com os animais $\mathrm{KO}$ (Ig total $0,1 \pm 0,01 \log _{2}$ e $\operatorname{IgG} 2 \mathrm{~b} 5,32 \pm 0,01 \log _{2}$ ), sendo ambos os resultados estatisticamente significantes.

Anticorpo - mortalidade

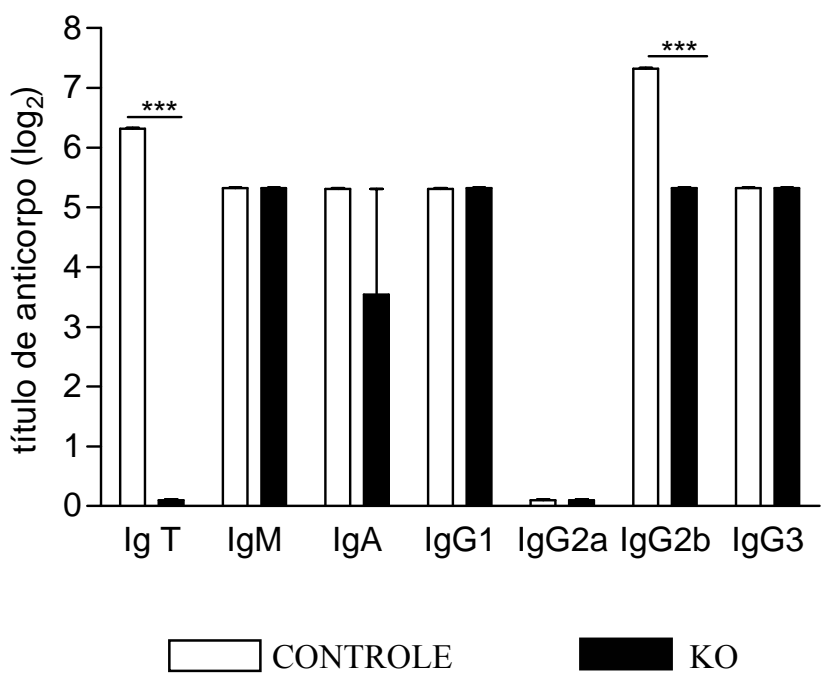

Figura 10: Quantificação dos isótipos de anticorpos específicos anti $P$. brasiliensis presentes no soro de animais CD28KO $(\mathrm{n}=4)$ e controle $(\mathrm{n}=4)$ após 365 dias de infecção com $1 \times 10^{6}$ leveduras de P. brasiliensis pela via i.t. $* * * \mathrm{p}<0,001$ 
RESULTADOS

\subsection{ANÁLISE DAS CITOCINAS DE PULMÃO E FÍGADO DOS ANIMAIS SOBREVIVENTES DO EXPERIMENTO DE MORTALIDADE}

Os níveis das citocinas também foram quantificados nos sobrenadantes de pulmão e fígado nos animais de ambas as linhagens, remanescentes dos experimentos da mortalidade. Os resultados estão apresentados na figura 11 (e anexo 4).

Não foram observadas diferenças significantes para as citocinas tipo 1 e tipo 2 nos homogenatos de pulmão. Pudemos observar, entretanto, diferenças significantes nos homogenatos de fígado. Observamos aumento de IL-2 (controle 1502,0 $\pm 185,0 \times$ CD28KO 957,0 \pm 91,0), IL-4 (controle 1033,0 \pm 126,0 x CD28KO 711,0 \pm 73,0), IL-10 (controle 2648,0 \pm $278,0 \times$ CD28KO 1983,0 \pm 133,0) e GM-CSF (controle 4716,0 $\pm 412,0$ x CD28KO 3122,0 \pm $263,0)$, sempre nos animais controle.
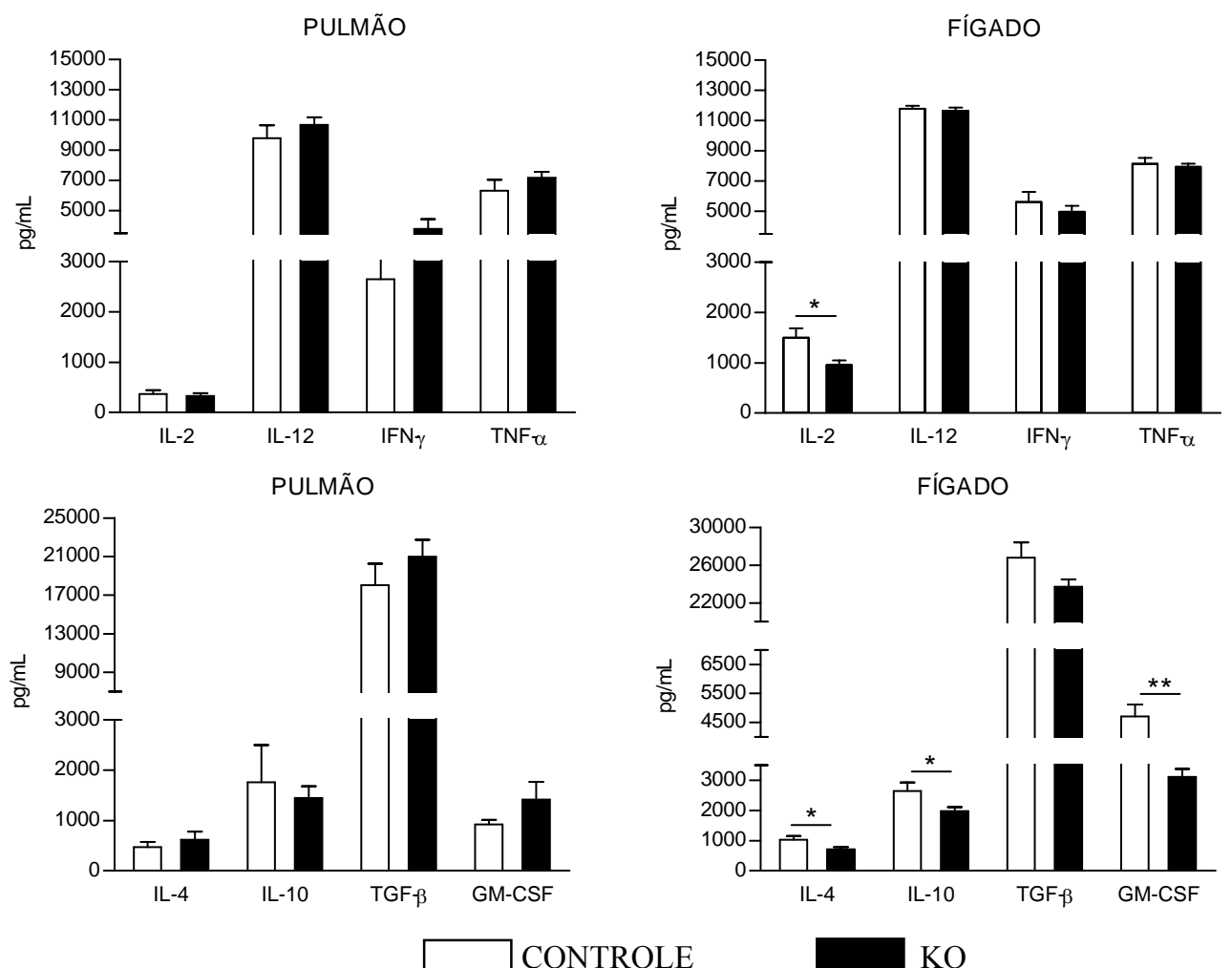

Figura 11: Quantificação de citocinas (pg/mL) nos homogenatos de pulmão e fígado de animais machos $(\mathrm{n}=4-11)$ C57B1/6 e C57B1/6 CD28KO sobreviventes da mortalidade após infecção i.t. com 1×106 leveduras de P. brasiliensis. $* * \mathrm{p}<0,01 * * * \mathrm{p}<0,001$ 


\subsection{ANÁLISE HISTOPATOLÓGICA}

Um parâmetro adicional para avaliar a gravidade da doença foi à análise histopatológica dos pulmões dos animais controle (WT) e deficientes para o CD28 (CD28KO) obtidos na segunda e décima semana pós-infecção i.t. pelo P. brasiliensis. A análise histopatológica foi também realizada nos pulmões dos animais sobreviventes do experimento de mortalidade.

As figuras 12, 13 e 14 exibem a histoarquitetura pulmonar sob coloração com hematoxilina \& eosina (H\&E). Na figura 12 os animais controle na segunda semana pós-infecção apresentam acúmulo de células epitelióides (EP) ao longo dos septos alveolares com ausência de necrose, caracterizando a presença de granuloma completo desprovido de necrose supurativa (A.1 aumento de 40x). Já os animais KO, apesar de exibirem histoarquitetura pulmonar preservada, não formam granulomas completos, mas sim esboços caracterizados por acúmulo esparso de células epitelióides entremeadas a linfócitos ( B.1 aumento de 10x). Em ambos os grupos de animais há raras formas do $P$. brasiliensis no interior das células epitelióides.
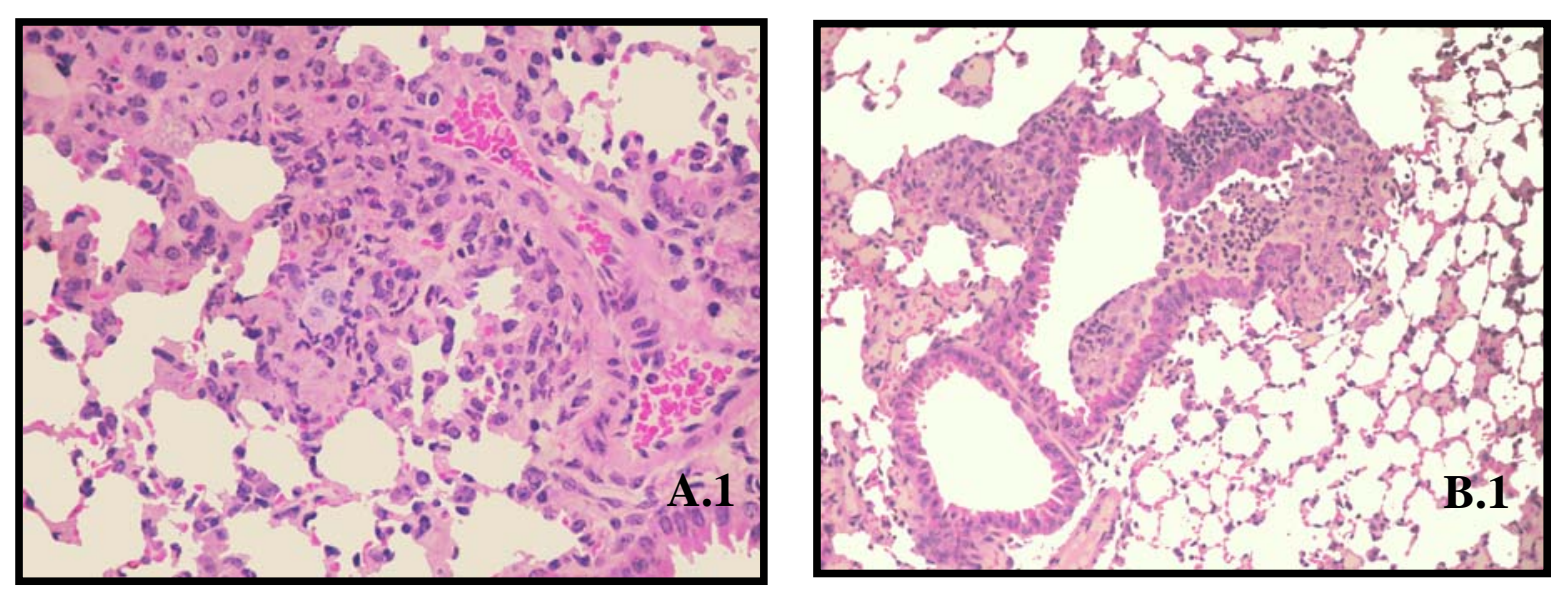

Figura 12: Fotografia das lesões pulmonares de animais C57B1/6 selvagens (controle) e C57B1/6 CD28KO (KO) infectados com $1 \times 10^{6}$ leveduras de P. brasiliensis na segunda semana de infecção. Coloração H\&E, (A.1 controle e B.1 CD28KO). 
RESULTADOS

Já em animais controle após 10 semanas de infecção (figura 13), evidencia-se o eixo broncoalveolar pulmonar preservado e todos os seus elementos: epitélio respiratório, mucosa, endotélio, camada muscular e periadventicial (A.2 aumento de 40x). Em contraste, nos animais $\mathrm{KO}$, a análise do parênquima pulmonar evidencia numerosos granulomas epitelióides com necrose supurativa central (B.2 aumento de 10x). Os granulomas são compostos por macrófagos que, por apresentarem núcleos vesiculosos e citoplasma amplo eosinofílico são chamados de células epitelióides. Estas formam arranjo radial ao redor de centro com necrose supurativa e periferia envolta por manguito linfocitário.

No interior das células epitelióides, identificam-se numerosas formas esféricas com tamanho variando de 3 a $10 \mu \mathrm{m}$, gemulantes, correspondentes à morfologia do fungo $P$. brasiliensis. Os granulomas distribuem-se ao longo da drenagem linfática pleuropulmonar em forma de lesões isoladas ou confluentes.

Ao longo do eixo broncoalveolar pulmonar, junto aos granulomas epitelióides, evidenciase exuberante hiperplasia do tecido linfóide associado aos bronquíolos (BALT). Parênquima pulmonar normal encontra-se intercalado às áreas contendo granulomas (B.2).
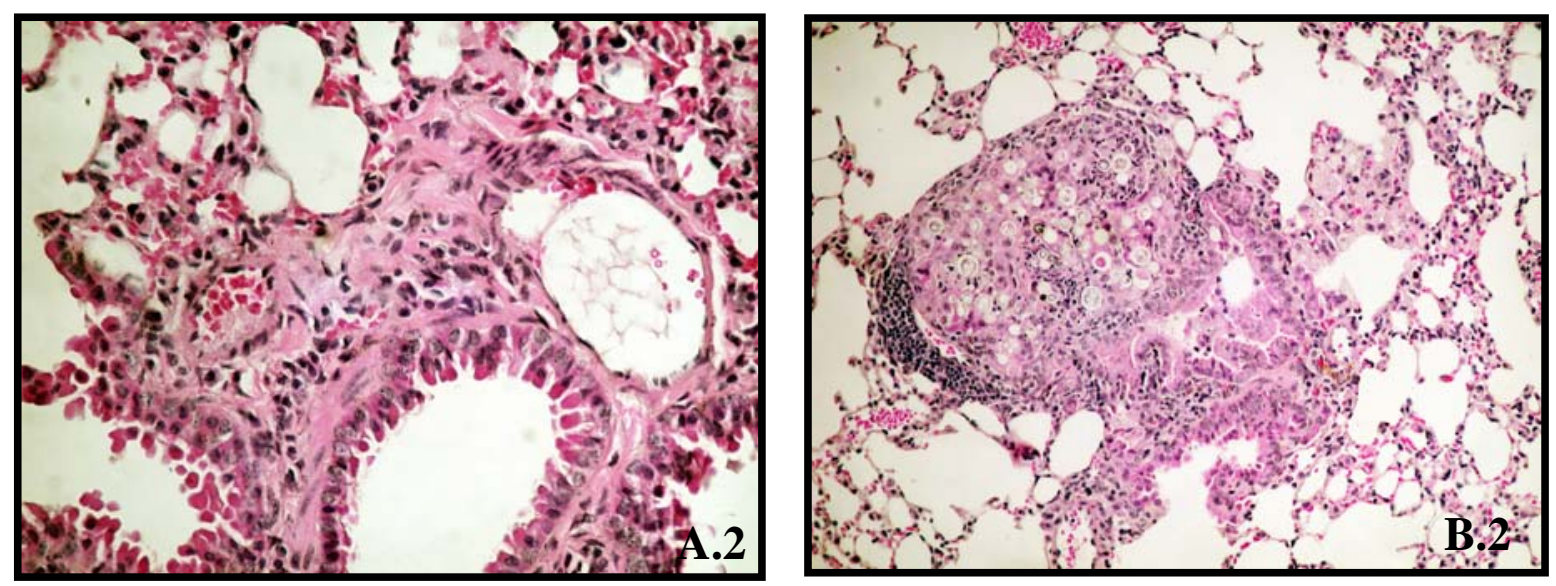

Figura 13: Fotografia das lesões pulmonares de animais C57Bl/6 selvagens (controle) e C57Bl/6 CD28KO (KO) infectados com $1 \times 10^{6}$ leveduras de $P$. brasiliensis na décima semana de infecção. Coloração H\&E, (A.2 controle e B.2 CD28KO). 
A figura 14 mostra a histopatologia dos animais controle e KO após 365 dias de infecção (experimento de mortalidade). Os animais controle mostram inflamação difusa em grande área do parênquima pulmonar e alvéolos levemente colapsados. No tecido pulmonar não se observam lesões sob a forma de granulomas epitelióides (A.3 aumento de 40x). Em contraste, os animais KO mostram numerosos granulomas epitelióides confluentes ou isolados substituindo parte da histoarquitetura pulmonar (B.3 aumento de 10x).
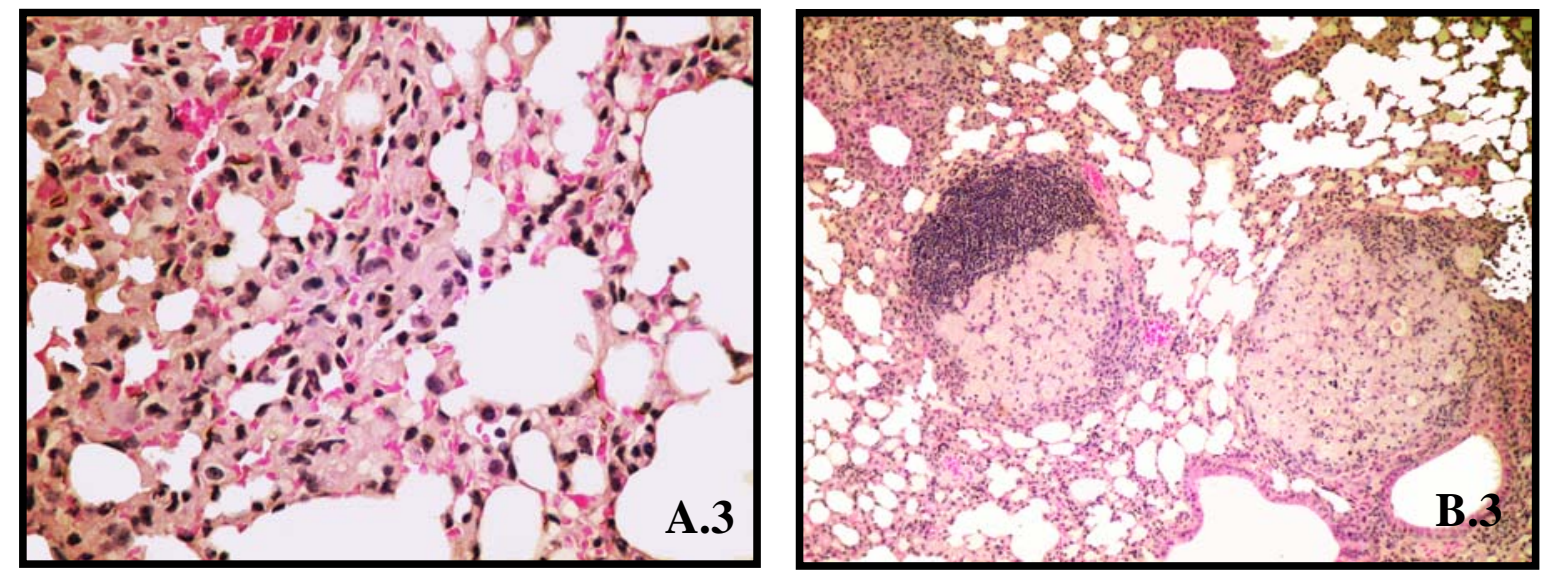

Figura 14: Fotografia das lesões pulmonares de animais C57Bl/6 selvagens (controle) e C57Bl/6 CD28KO (KO) infectados com $1 \times 10^{6}$ leveduras de P. brasiliensis após 365 dias de infecção. Coloração H\&E, (A.3 controle e B.3 CD28KO). 
RESULTADOS

4.11 EXPERIMENTO DE IMUNOPROTEÇÃO: AVALIAÇÃO DA GRAVIDADE DA INFECÇÃO POR UFC.

Trabalho anterior desenvolvido em nosso laboratório (Arruda et al., 2007) demonstrou que se pode induzir imunidade protetora a PCM através da pré-imunização de camundongos com fungos viáveis pela via sub-cutânea. Utilizamos, então, este protocolo para verificar se camundongos CD28-deficientes eram capazes de desenvolver imunoproteção equivalente à dos camundongos normais.

Nos experimentos de imunoproteção, tanto camundongos controle como CD28KO foram pré-imunizados pela via s.c. com $5 \times 10^{6}$ leveduras viáveis de $P$. brasiliensis e 15 dias após desafiados por infecção i.t. com um milhão de leveduras. Camundongos inoculados com PBS pela via s.c. foram usados como controle. O número de fungos viáveis nos órgãos foi determinado 8 semanas após o desafio i.t.

Os animais foram sacrificados, um dos pulmões, um lóbulo do fígado e parte do baço foram removidos, pesados, macerados e plaqueados em ágar BHI suplementado. O número de colônias foi contado durante 15 dias e o número final transformado em $\log _{10} / \mathrm{g}$ de tecido.

$\mathrm{Na}$ figura 15 podemos observar carga fúngica significantemente maior nos animais CD28KO não imunizados $\left(6,19 \pm 0,04 \log _{10}\right)$ quando comparados com os animais CD28KO imunizados $\left(3,41 \pm 0,04 \log _{10}\right)$. O mesmo fenômeno pôde ser observado nos animais controle: os não imunizados apresentaram carga fúngica $\left(4,2 \pm 0,28 \log _{10}\right)$ maior que os pré-imunizados $\left(1,87 \pm 0,1 \log _{10}\right)$. Ambos os resultados foram estatisticamente significantes.

Já no fígado, pudemos observar diferença estatisticamente significante entre os animais CD28KO sendo que os animais não imunizados $\left(3,0 \pm 0,01 \log _{10}\right)$ apresentaram maior número de fungos viáveis quando comparados com os animais imunizados $\left(0,1 \pm 0,01 \log _{10}\right)$. No fígado dos animais controle não houve diferenças entre os grupos. 
PULMÃO

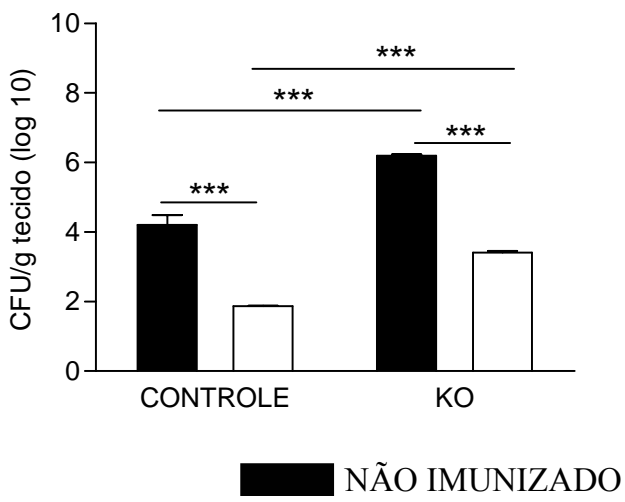

FÍGADO

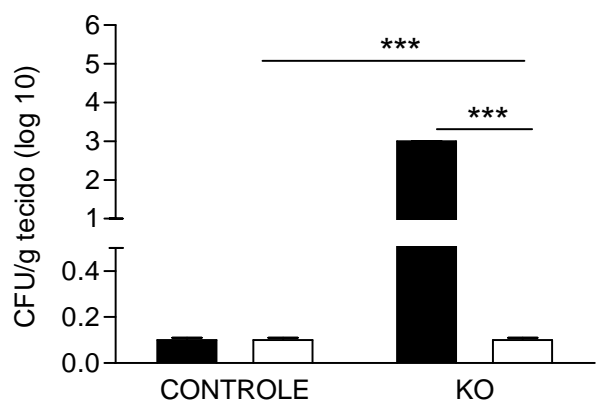

IMUNIZADO

Figura 15. Experimento de imunoproteção. Avaliação da gravidade da doença por contagem do número de Unidades Formadoras de Colônias (UFC)/g de tecido (em $\log _{10}$ ) dos camundongos machos CD28KO (n=3-5) e controle ( $\mathrm{n}=3$ 5). Os camundongos foram analisados 8 semanas após o desafio i.t. com um milhão de fungos $* * * \mathrm{p}<0,001$.

\subsection{EXPERIMENRO DE IMUNOPROTEÇÃO: DETERMINAÇÃO DO NÍVEL DE ANTICORPOS ANTI P. BRASILIENSIS}

Seguindo o mesmo protocolo descrito no item 4.3, o nível dos anticorpos anti- $P$. brasiliensis foi quantificado no soro dos animais utilizados no experimento de imunoproteção.

Conforme mostrado na figura 16 (A e B), a maioria dos isótipos não apresentou diferenças significantes entre os grupos imunizados e não imunizados. Deve-se notar que, mais uma vez, camundongos CD28KO produzem quantidades muito menores de anticorpos IgG que animais controle.

Pudemos apenas notar diferenças entre o isótipo IgA que apresentou-se mais elevado nos animais controle (WT) não imunizados $\left(6,57 \pm 0,25 \log _{2}\right)$ quando comparados com os animais controle imunizados $\left(5,32 \pm 0,01 \log _{2}\right)$. $\mathrm{O}$ mesmo fenômeno pôde ser observado para o isótipo $\operatorname{IgG} 2 \mathrm{a}$ onde os animais controle não imunizados $\left(5,32 \pm 0,01 \log _{2}\right)$ apresentaram valores mais elevados quando comparados com os dos animais controle imunizados $\left(0,1 \pm 0,01 \log _{2}\right)$. 
RESULTADOS

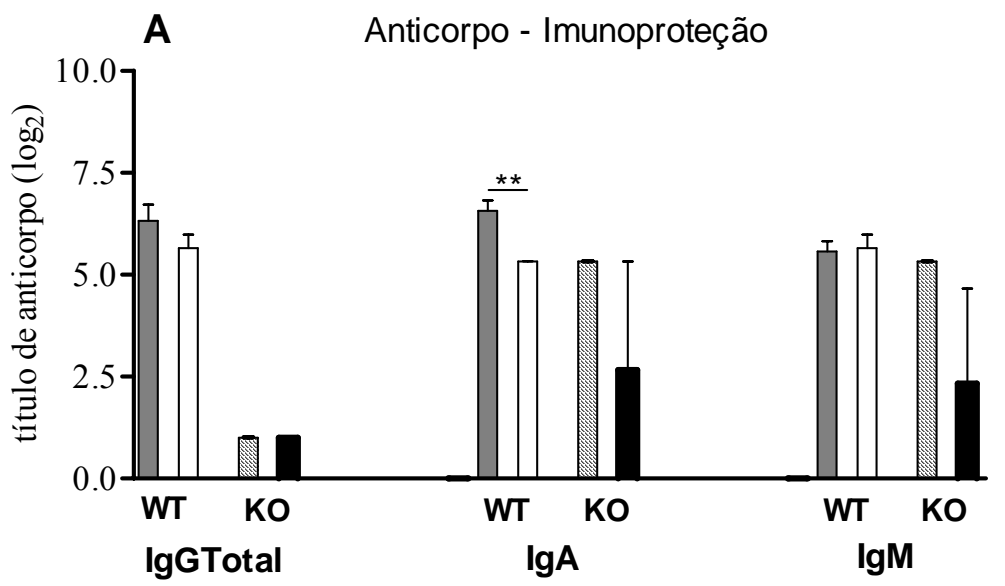

B Anticorpo - Imunoproteção

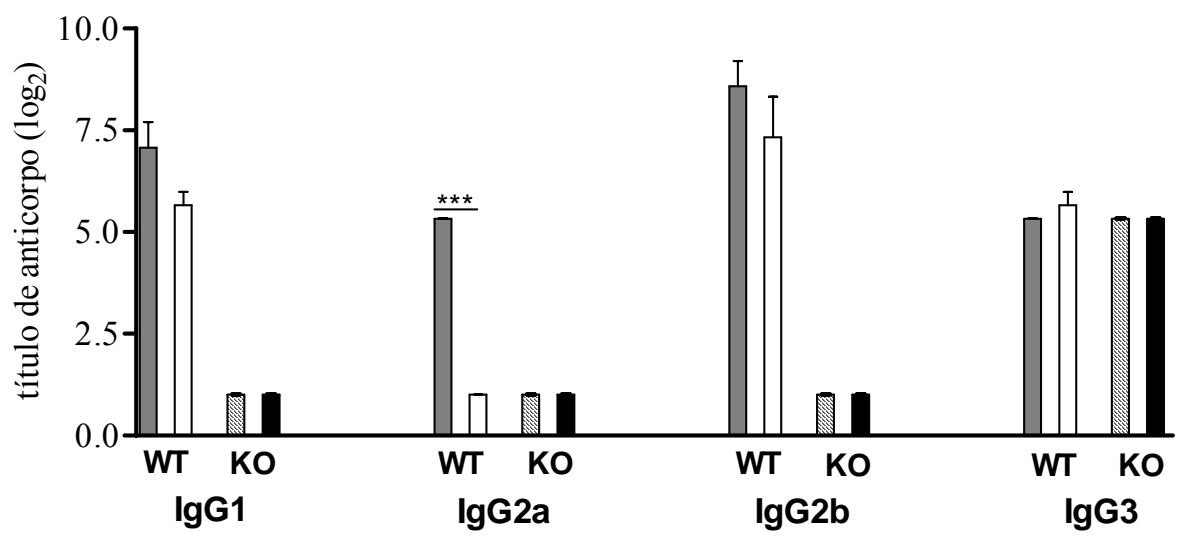

WT não imunizado

WT imunizado KO imunizado

Figura 16: Experimento de imunoproteção. Quantificação dos isótipos de anticorpos específicos anti-P. brasiliensis presentes no soro de animais $\mathrm{CD} 28 \mathrm{KO}(\mathrm{n}=3-5)$ e controle $(\mathrm{n}=3-5)$. Os camundongos foram analisados 8 semanas após o desafio i.t. com um milhão de fungos.

$* * \mathrm{p}<0,01 * * * \mathrm{p}<0,001$ 


\subsection{EXPERIMENTO DE IMUNOPROTEÇÃO: ANÁLISE DAS CITOCINAS DE PULMÃo E FÍGADO}

Os níveis das citocinas foram quantificados no sobrenadante de pulmão e fígado dos animais utilizados no experimento de imunoproteção. Os resultados estão apresentados na figura 17 (e anexo 5).

Pudemos observar que não houve diferenças significantes para as citocinas tipo 1 quantificadas nos homogenatos de pulmão e fígado (figura A e B). Entretanto foram observadas diferenças significantes para as citocinas tipo 2 nos homogenatos de pulmão e fígado.

Na figura $\mathrm{C}$ o nível de TGF- $\beta$ apresentou-se aumentado no sobrenadante de pulmão dos camundongos CD28KO imunizados $\left(19695,0 \pm 177,0 \log _{10}\right)$ quando comparado com o observado nos camundongos CD28KO não imunizados $\left(14577,0 \pm 38,0 \log _{10}\right)$.

O mesmo aconteceu com esta citocina no sobrenadante de fígado (figura D), onde os camundongos CD28KO imunizados $\left(23938,0 \pm 356,0 \log _{10}\right)$ apresentam níveis mais elevados do que os camundongos CD28KO não imunizados $\left(16679,0 \pm 163,0 \log _{10}\right)$.

Por outro lado, a citocina IL-10 apresentou-se aumentada no sobrenadante de fígado dos camundongos controle (WT) imunizados $\left(2382,0 \pm 176,0 \quad \log _{10}\right)$ quando comparados com camundongos controle imunizados $\left(1511,0 \pm 298,0 \log _{10}\right)$. 


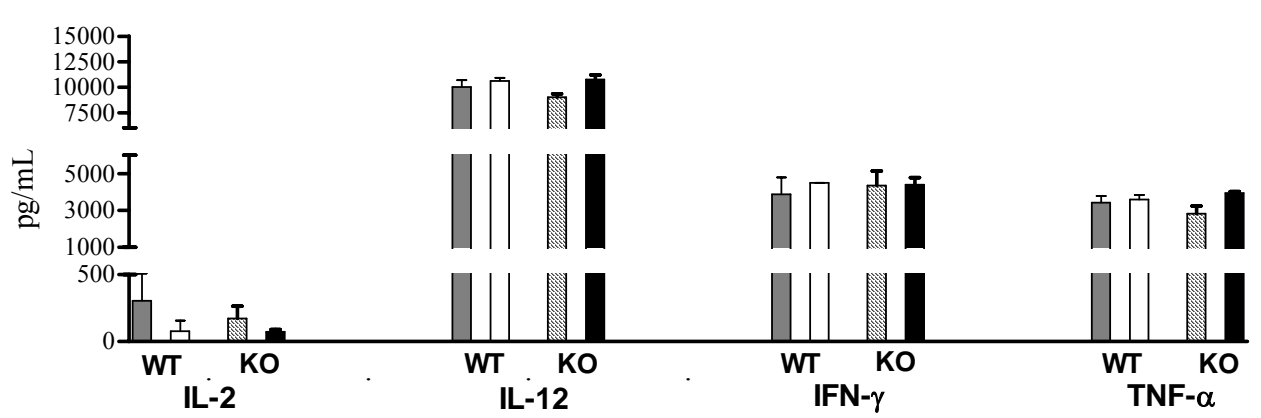

B

Citocinas tipo 1 fígado - Imunoproteção

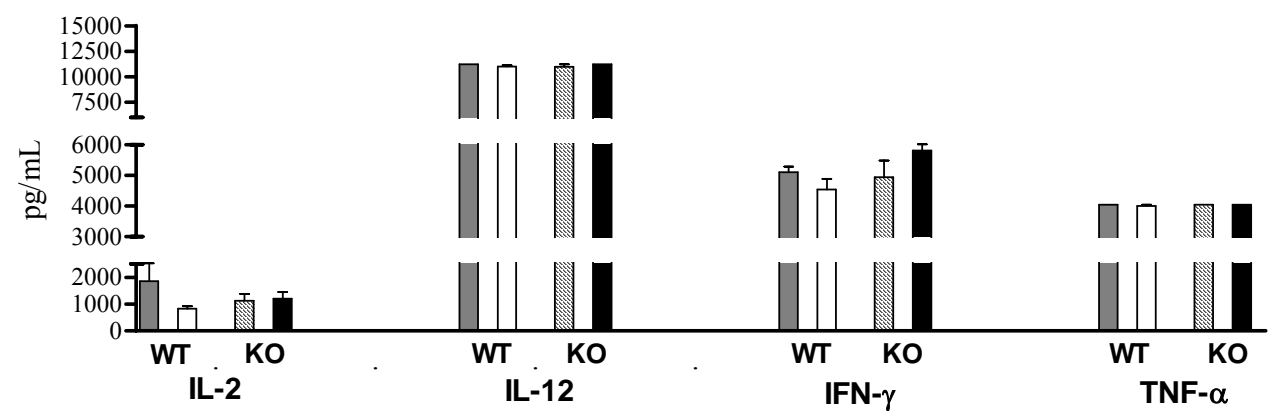

C

Citocinas tipo 2 pulmão - Imunoproteção

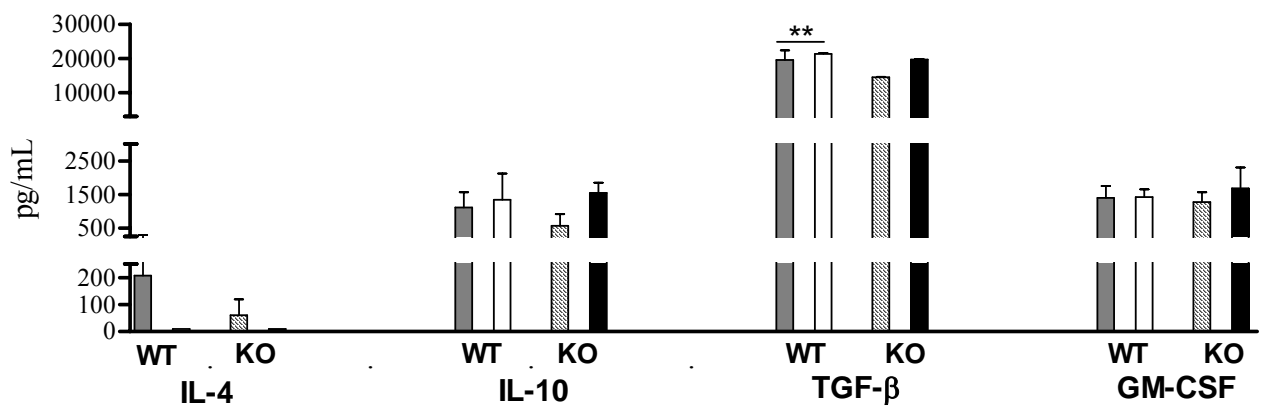

D

Citocinas tipo 2 fígado - Imunoproteção

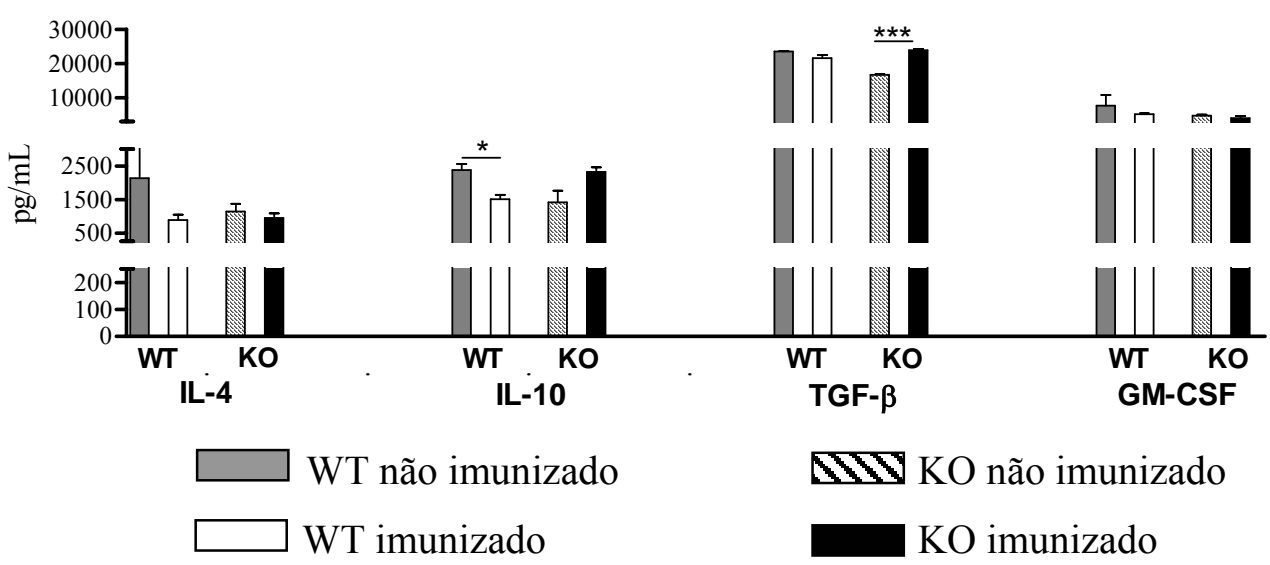

Figura 17: Experimento do imunoproteção. Quantificação de citocinas tipo 1 e tipo 2 (pg/mL) nos homogenatos de pulmão e fígado de animais machos $(\mathrm{n}=4) \mathrm{C} 57 \mathrm{Bl} / 6$ e C57B1/6 CD28KO. Os camundongos foram analisados 8 semanas após o desafio i.t. com um milhão de fungos.

$* \mathrm{p}<0,05 * * * \mathrm{p}, 0,001$ 
DISCUSSÃO 
DISCUSSÃO

A molécula CD28 é fundamental para a ativação de linfócitos $\mathrm{T}$ e para a resposta imune celular. A ligação do CD28 na superfície do linfócito T com seus ligantes B7-1 (CD80) ou B7-2 (CD86) expressos nas APCs iniciam um potente sinal co-estimulatório e esta interação direciona a proliferação, diferenciação e produção de citocinas destes linfócitos (Chambers \& Allison, 1999).

Como a resposta imune celular é considerada o mecanismo mais importante na defesa do hospedeiro contra P. brasiliensis (revisto por Musatti et al., 1993), e nesta resposta participam macrófagos ativados por citocinas derivadas de linfócitos $\mathrm{T} \mathrm{CD}^{+}$e $\mathrm{T} \mathrm{CD} 8^{+}$(Calich \& Blotta, 2005), resolvemos estudar a importância da molécula CD28 nos mecanismos de imunidade contra o fungo.

Nossos estudos permitiram verificar que:

$\checkmark$ a molécula CD28 interfere no controle da carga fúngica nas segunda e décima semanas pós-infecção, uma vez que os animais CD28KO machos apresentam um número de fungos viáveis no pulmão significantemente mais alto que nos controles;

$\checkmark$ a molécula CD28 controla os níveis de anticorpos e citocinas sintetizados;

$\checkmark$ a molécula CD28 interfere na sobrevida dos animais, pois os camundongos CD28KO infectados têm sobrevida significativamente maior que os camundongos controle, apesar da imensa carga fúngica tecidual;

$\checkmark$ a ausência da molécula CD28 não abole o fenômeno de imunoproteção induzido por préimunização dos animais por via sub-cutânea.

Na fase aguda da PCM (72 horas de infecção) o CD28 não é importante para controlar a carga fúngica pulmonar dos animais machos. O mesmo fenômeno pôde ser observado em animais CD28KO infectados com Candida albicans, onde se verificou que a molécula CD28 não é requerida para o controle da infecção na sua fase inicial (Montagnoli et al., 2002). Este fenômeno era já esperado, pois a função co-estimulatória da molécula CD28 ocorre na fase de ativação da imunidade adaptativa, onde participa ativamente na estimulação de linfócitos $\mathrm{T}$. Na fase de imunidade inata, esta molécula parece não exercer efeito regulador do processo inflamatório. 
Em elegante trabalho, descreveu-se, entretanto, a importância da molécula CD28 tanto na resposta imune inata como na adaptativa contra o Pneumocystis carinii. Animais deficientes da molécula CD28 mostraram-se mais susceptíveis à infecção por este fungo e desenvolveram uma pneumonia aguda que foi subseqüentemente resolvida através de processo inflamatório contendo células de diversos fenótipos, incluindo um grande número de células T $\mathrm{CD} 8^{+}$; observou-se, entretanto, diminuição significante na produção de anticorpos específicos (Beck et al., 2003).

Nossos estudos demonstraram, entretanto, que nos períodos de 2 e 10 semanas de infecção, a molécula CD28 é importante para o controle do crescimento fúngico no pulmão, uma vez que animais KO apresentaram aumento significante de carga fúngica quando comparados com os animais controle.

Assim, a molécula CD28 também influencia a gravidade da PCM pulmonar. Este achado poderia ser explicado pelo fato dos animais CD28KO apresentarem o desenvolvimento da imunidade celular prejudicado devido à deficiência da ativação dos linfócitos $T$, uma vez que para esta ativação ser eficiente é necessária a presença de um segundo sinal, usualmente mediado pela molécula CD28. Assim, estes animais não seriam capazes de ativar a resposta imune celular e seus mecanismos efetores mediados por linfócitos $\mathrm{T}$, e não poderiam controlar a carga fúngica.

Com relação à imunidade humoral, na segunda semana de infecção, os animais CD28KO e controle apresentaram níveis muito baixos de IgG; entretanto, os níveis da imunoglobulina IgM foram estatisticamente mais elevados no grupo controle. Este isótipo, no trabalho de Couper et al. (2005), é descrito como extremamente importante para modulação da infecção precoce pelo Toxoplasma gondii, pois limita a entrada do parasita na célula do hospedeiro e reduz a disseminação sistêmica. Na PCM não foi demonstrada nenhuma atividade protetora relacionada à produção de anticorpos, sejam eles $\operatorname{IgM}, \operatorname{IgG}$ ou $\operatorname{IgA}$. Entretanto, a baixa produção de $\operatorname{IgG}$ observada na segunda semana pós-infecção já demonstra uma deficiência inicial da ativação do compartimento B da resposta imune. No período de 10 semanas de infecção, pudemos observar títulos de IgG total, IgG1, IgG2a e IgG2b significativamente diminuídos nos animais CD28KO, porém esta diminuição não foi observada para IgM, IgA e IgG3. Este fato não é usual na PCM, 
uma vez que nos animais machos controle ocorreu infecção mais branda e o título de anticorpos foi maior.

Os níveis muito baixos, quase ausentes, de IgG1, IgG2a e IgG2b nos camundongos CD28KO sugerem que a produção de citocinas, entre elas a IL-4, o IFN- $\gamma$ e o TGF- $\beta$, deveria estar bastante prejudicada nestes animais. Este dado indicou que houve uma ativação inadequada de linfócitos T, uma vez que na PCM experimental a produção de anticorpos é quase que exclusivamente um fenômeno T-dependente (Burger et al., 1996). Este fato é bastante interessante e contraria um dos paradigmas da resposta imune na PCM. Nesta micose profunda, a produção de anticorpos é proporcional à gravidade da doença, isto é, níveis muito elevados ocorrem com quadros graves e disseminados da infecção (revisto por Brummer et al., 1993, Restrepo, 1988, Blotta \& Calich, 2005). No nosso trabalho, ocorreu infecção mais grave associada a níveis baixos de anticorpos. Entretanto, a T-dependência da maioria dos antígenos de P. brasiliensis, explicaria este fato.

Em conjunto, nossos resultados permitem sugerir que na PCM, a produção de anticorpos é dependente da molécula CD28, uma vez que animais CD28KO produziram níveis muito baixos dos mesmos.

Camundongos CD28-deficientes não desenvolvem centros germinativos e não fazem a mudança de isótipos (switch) de IgG e nem apresentam maturação de afinidade dos anticorpos (Lenschow et al., 1996). Além disso, camundongos deficientes na sinalização celular mediada por CD28 deixam de expressar altos níveis de OX40, uma outra molécula co-estimulatória, e isto foi associado à baixa produção de IL-4 e à baixa expressão do receptor de quimiocina CXCR5 em células $\mathrm{T} \mathrm{CD}^{+}$, uma molécula envolvida na migração de linfócitos para os centros germinativos (Walker et al., 1999). Assim, nossos resultados de quase ausência de produção de isótipos de $\mathrm{IgG}$ devem refletir esta falha funcional que afeta tanto linfócitos $\mathrm{T}$ como linfócitos $\mathrm{B}$ em camundongos CD28KO.

Em trabalho com $P$. chabaudi verificou-se que após 3 meses de infecção os soros dos animais $\mathrm{KO}$ eram negativos para anticorpos IgG específicos, em concomitância com a falha na erradicação do parasita. Mesmo após a re-infecção destes animais não se observou uma resposta secundária de produção de IgG e os parasitas não eram eliminados. Em contrapartida, o soro dos 
animais controle re-infectados apresentavam altos títulos de IgG2a específicos. Desta forma, para a produção de anticorpos IgG necessários para a proteção contra $P$. chabaudi é fundamental a presença da molécula CD28 que não pôde ser substituída por outros sinais co-estimulatórios (Elias et al., 2005). Relacionando este resultado com aquele por nós obtido, observamos uma coincidência quanto à deficiência na produção de anticorpos IgG específicos nos animais CD28KO. Assim, esta molécula é também fundamental para a produção dos isótipos específicos anti-P.brasiliensis.

O estudo do padrão das citocinas no curso da paracoccidioidomicose induzida pela inoculação i.p. do fungo em camundongos susceptíveis (B10.A) e resistentes (A/J) demonstrou que os linfócitos de camundongos resistentes estimulados por antígeno solúvel do fungo produzem altos níveis de IFN- $\gamma$ e IL-2, enquanto que os camundongos susceptíveis são incapazes de sintetizar estas citocinas. Ao contrário, estes animais iniciam a síntese de IL-10 em um período bem precoce da doença e a IL-5 em altos níveis poderia ser usada como um marcador da ativação Th2 (Calich \& Kashino, 1998; Kashino et al., 2000).

Quando a via de inoculação foi a i.t. foi possível observar tanto citocinas do tipo 1 como do tipo 2 no sobrenadante de pulmão de ambas as linhagens (susceptíveis e resistentes). Nas quarta e oitava semanas de infecção, os níveis das citocinas IFN- $\gamma$, IL-4, IL-5 e IL-10 apresentaram-se mais elevados nos camundongos susceptíveis, porém as citocinas tipo 2 pareciam predominar, uma vez que somente estes animais desenvolvem infecção progressiva concomitante com a ativação ausente de macrófagos pulmonares (Cano et al., 1998).

Certas citocinas como o IFN- $\gamma$ e a IL-12 exercem um efeito protetor contra a doença causada pelo $P$. brasiliensis. Este fato foi observado em experimentos onde a depleção in vivo do IFN- $\gamma$ agravou a doença tanto em camundongos susceptíveis como resistentes (Cano et al., 1998). Além disso, o tratamento de camundongos susceptíveis com IL-12 recombinante levou a uma doença menos grave com aumento de níveis de IFN- $\gamma$ ao início da infecção. Por outro lado, a IL12 exógena apesar de diminuir a carga fúngica no fígado e baço, induziu um aumento do infiltrado inflamatório no pulmão. A depleção desta citocina através de anticorpos monoclonais específicos levou a doença mais grave em camundongos susceptíveis e resistentes. O efeito 
protetor da citocina IL-12 na PCM foi também caracterizada em camundongos nocautes de IL-12 (IL-12 KO) que apresentaram doença extremamente grave e morte precoce (Calich et al.,1998; Deepe et al., 2000; Murphy et al., 1994).

O IFN- $\gamma$ controla a multiplicação de fungos por fagócitos, como demonstrado por diversos pesquisadores (Brummer, 1994; Cano et al., 1998; Moscardi-Bacchi et al., 1994). Tal citocina parece ser o mais importante mediador da resistência contra a infecção causada pelo $P$. brasiliensis e seu efeito protetor pode ser atribuído à atividade anti-fúngica que induz nos macrófagos que se tornam capazes de produzir óxido nítrico, um potente mediador da morte do fungo. Pode também ativar a atividade fungicida dos leucócitos polimorfonucleares que exercem sua atividade fungicida através da síntese de radicais reativos de oxigênio (Brummer, 1994).

Uma outra citocina estudada na PCM é a IL-4 que parece ter um efeito antagônico na doença. A neutralização da IL-4 in vivo levou a um aumento da carga fúngica pulmonar nos camundongos B10.A (Arruda et al., 2004). Por outro lado, camundongos C57B1/6 nocaute para IL-4 (IL-4 KO) apresentaram cargas fúngicas menores no pulmão e fígado, porém o número de fungos viáveis no baço não se alterou (Calich et al., 1994; Deepe et al., 2000; Pina et al., 2004).

Para melhor caracterizar a resposta imune nos camundongos CD28KO e seus controles normais quantificamos as citocinas produzidas no pulmão e fígado em resposta à infecção pelo fungo $P$. brasiliensis. Demonstramos que os níveis de algumas citocinas encontravam-se alteradas nos animais deficientes. No período de 72 horas pós-infecção, os animais não apresentaram diferenças entre os níveis de citocinas sintetizados. Na segunda semana da doença, porém, os animais CD28KO apresentaram níveis de IL-2, IL-4 e GM-CSF no sobrenadante de fígado menores do que no grupo controle.

$\mathrm{Na}$ décima semana pós-infecção os homogenatos de pulmões de animais CD28KO apresentavam valores diminuídos de IL-12 e TNF- $\alpha$ e aumentados de IL-5. É difícil interpretar este último achado, mas uma análise geral indica uma deficiência generalizada da produção de citocinas, com destaque para as do tipo 1. Já no fígado de animais machos deficientes para CD28 observamos uma diminuição de citocinas tipo 1 ( IL-12, IFN- $\gamma$ e TNF- $\alpha$ ) e tipo 2 (IL-10) na décima semana da doença. Assim, no fígado, tanto as citocinas pró como anti-inflamatórias 
encontravam-se diminuídas nos animais machos CD28 KO o que talvez possa ser explicado pelo menor infiltrado de células no fígado observado na histopatologia. Como, entretanto, às 10 semanas de infecção havia uma carga fúngica significantemente maior nos animais deficientes, pode-se sugerir que a resposta imune prejudicada possibilitou a maior multiplicação do $P$. brasiliensis nos órgãos de disseminação.

Como um todo, pode-se afirmar que na PCM a deficiente resposta T-dependente de animais CD28KO resultou em menor síntese de citocinas sejam elas do tipo 1, tipo 2 ou fator de crescimento. Diferente desta observação, 2 semanas após a infecção por Pneumocystis carinii observou-se um aumento de IL-10 e IFN- $\gamma$ em homogenatos de pulmão de camundongos nocautes de CD28 quando comparados com camundongos controle. O mesmo fenômeno foi observado na quarta semana de infecção (Rose et al., 2005). Talvez com este fungo, a imunidade inata compense melhor a falha da imunidade adaptativa e seja responsável pela secreção aumentada de IL-10 e IFN- $\gamma$. Trabalho realizado com outro fungo, a C. albicans, demonstra que após uma semana de infecção os camundongos nocautes de CD28 apresentam níveis menores de IFN- $\gamma$ quando comparados com outras linhagens de camundongos em estudo (nocaute de B7-1 e de B7-2 e controle BALB/c). Por outro lado, os camundongos nocautes de CD28 não apresentaram alteração nos níveis de IL-12, IL-4 e IL-10 em relação aos outros camundongos (Montagnoli et al., 2002).

Outro interessante trabalho demonstrou a importância da molécula co-estimulatória CD28 para a produção do IFN- $\gamma$ pelos linfócitos T em resposta à infecção pelo Trypanosoma cruzi. A ausência da molécula CD28 esteve acompanhada com a produção reduzida de IFN- $\gamma$ e NO na fase aguda da infecção e os linfócitos TCD4+ e TCD8+ apresentaram-se deficientes quando à produção de IFN- $\gamma$ ( Martins et al., 2004).

Elias et al. (2005) relataram que, apesar dos baixos níveis de IFN- $\gamma$ secretados pelos linfócitos $\mathrm{T} \mathrm{CD}^{+}$e $\mathrm{T} \mathrm{CD}^{+}$de camundongos nocautes de $\mathrm{CD} 28$, a produção de $\operatorname{IgM}$ e outras moléculas efetoras do sistema imune inato poderiam ter sido suficientes para o controle da primeira onda de crescimento do P. chabaudi. Na PCM pulmonar, entretanto, a baixa síntese de citocinas resulta em infecção exacerbada indicando que mecanismos efetores da imunidade 
adaptativa são CD28-dependentes e que mecanismos efetores de imunidade inata não substituem aqueles da imunidade adquirida.

Em conjunto, os resultados caracterizando a carga fúngica e a produção de anticorpos e citocinas revelam que os animais CD28-deficientes desenvolvem uma resposta imune efetora pouco eficiente para o controle do fungo. Esta deficiência é observada através da síntese diminuída de vários isótipos de anticorpos e pela produção diminuída de citocinas, principalmente as pró-inflamatórias. São estas citocinas (IFN- $\gamma$, TNF- $\alpha$ e IL-12) que são as principais ativadoras de fagócitos e NO-sintase, que, através do NO, exercem efeito fungicida sobre o P. brasiliensis (Gonzalez et al., 2000, Calich \& Blotta 2005).

Sabe-se que a molécula CD28 é requerida tanto para a ativação de células T-naive (T $\mathrm{CD} 4^{+} \mathrm{CD} 25^{-}$) como para a expansão das células T-regulatórias ( $\mathrm{T} \mathrm{CD} 4^{+} \mathrm{CD} 25^{+} \mathrm{Foxp}^{+}$). Além disso as células $\mathrm{T} \mathrm{CD} 25^{-}$são mais sensíveis à co-estimulação pelo $\mathrm{CD} 28$ que as células T regulatórias que entretanto, também dependem desta molécula para a sua expansão (Liu et al., 2006).

Apesar de não termos realizado a análise fenotípica e funcional das células dos infiltrados inflamatórios e dos linfonodos drenantes de pulmões, nossos dados sugerem que a ausência de CD28 levou a uma resposta imune efetora muito prejudicada, principalmente a do tipo 1, produtora de citocinas pró-inflamatórias requeridas para o efeito fungicida dos fagócitos contra o P. brasiliensis. Além disso, pode-se esperar nos animais CD28KO ocorra a expansão diminuída de células $\mathrm{T}$ regulatórias, o que possibilitaria a expansão de células $\mathrm{T}$ efetoras através de outros pares de estímulos co-estimulatórios tais como ICOS-ICOSL, ICAM-LFA-1, VLA-4-VCAM (Damle et al., 1993). Nos animais controle haveria, ao contrário, uma resposta imune eficiente, com síntese de mediadores pró-inflamatórios responsáveis pelo controle do crescimento fúngico. Nestes animais, entretanto, a expansão das células $\mathrm{T}$ regulatórias não estaria prejudicada e possibilitaria o estabelecimento de lesões involutivas que, de fato, caracteriza a patologia destes animais. 
A molécula CD28 parece também influenciar indiretamente a produção de NO. Nos animais machos CD28-deficientes observamos diminuição da síntese de NO no sobrenadante de fígado após 10 semanas de infecção quando comparado com os animais contole. Esta diminuição pode estar relacionada com os níveis mais baixos de IFN- $\gamma$ e de TNF- $\alpha$ observado nos animais deficientes. Mc Micking et al. (1997) relatou que o efeito microbicida do NO em infecções de fagócitos ocorre de duas maneiras: primeiro o IFN- $\gamma$ e TNF- $\alpha$ (produzidos por células T ou outras células) ativam os macrófagos promovendo a expressão de iNOS e síntese de NO. Segundo, durante a fagocitose aumenta o "burst" oxidativo, além da atividade citostática e citotóxica sobre os microorganismos. A síntese diminuída do NO explicaria o maior crescimento fúngico nos animais $\mathrm{KO}$ em comparação aos animais controle. Este fato seria o reflexo da síntese diminuída de citocinas pró-inflamatórias nos pulmões e fígado dos animais CD28KO infectados. Realmente, na PCM murina o principal mecanismo fungicida de fagócitos é mediado pelo NO (Gonzalez et al., 2007). A síntese exacerbada deste mediador, entretanto, resulta em resposta imune celular diminuída (Bocca et al., 1998, Nascimento et al., 2002). Há ainda uma nítida correlação entre os níveis de NO e a síntese de TNF- $\alpha$ e organizações das lesões granulomatosas. O tratamento de animais infectados pelo P. brasiliensis com inibidores de NO-sintase leva a cargas fúngicas aumentadas, porém, associado à maior síntese de TNF- $\alpha$, ocorre a maior organização dos granulomas que parecem evitar a disseminação do fungo (Bocca et al., 1998, Nascimento et al., 2002, Bernardino, 2006). No presente trabalho, como animais CD28KO fazem níveis diminuídos de NO, não se pode atribuir a este mediador a provável deficiência na expansão de células Tefetoras.

Um achado muito interessante, porém de difícil explicação, foi a maior mortalidade dos animais controle quando comparada à dos animais CD28-deficientes, mostrando ser esta independente da carga fúngica. É impressionante o número de fungos no pulmão $\left(>4,8 \log _{10}\right)$ e no fígado $\left(>2,2 \log _{10}\right)$ de animais $\mathrm{CD} 28 \mathrm{KO}$ sobreviventes aos 365 dias pós-infecção. Seus controles neste mesmo período haviam aparentemente esterilizado a infecção, uma vez que não foram recuperadas leveduras viáveis destes animais e a histopatologia mostrava-se negativa quanto à presença de fungos. Além disso, comparados aos controles normais, os animais CD28KO sobreviventes apresentaram menores níveis de IL-2, IL-4, IL-10 e GM-CSF no fígado. 
Da mesma maneira, observamos nestes animais marcante diminuição de IgG (principalmente IgG2b). Mais uma vez, a produção de anticorpos não pôde ser relacionada com o aumento da carga fúngica (gravidade da doença), uma vez que camundongos CD28KO apresentaram números de fungos viáveis recuperados significantemente maiores do que seu grupo controle. Como um todo, o experimento de sobrevida demonstra que uma carga fúngica exacerbada associada à resposta imune deficiente não se traduz em alta mortalidade. Ao contrário, os animais CD28-normais, que no curso da infecção desenvolvem resposta imune eficiente e aparentemente chegam a eliminar totalmente o $P$. brasiliensis, é que apresentam maior mortalidade.

Nesta fase de nosso trabalho é tentador especular que a resposta imune mais eficiente desenvolvida no curso da infecção de animais CD28-normais levaria à morte dos animais infectados. Sobreviveriam somente aqueles cuja resposta foi menos exacerbada e que aos poucos iriam controlando o crescimento fúngico sem, contudo, levar a patologia tissular. Nos animais CD28KO a deficiência de resposta T-dependente resultaria em falha de controle do crescimento fúngico, que, entretanto, não seria deletério para o hospedeiro e causaria menor dano tecidual. A existência de infecções mais graves ou maior mortalidade associadas à resposta imune eficiente ou exacerbada é um fato recorrente em nosso modelo experimental (Calich et al., 2007). Assim, em trabalho anterior, verificamos que camundongos susceptíveis apresentam macrófagos alveolares que têm maior capacidade fungicida, de secreção de NO e síntese de IL-12 maior que os de animais resistentes (Pina, 2005). A inoculação de IL-12 recombinante em camundongos susceptíveis leva à síntese precoce de IFN- $\gamma$ e menor disseminação fúngica, mas acarreta intensa patologia pulmonar (Arruda et al., 2002). Camundongos susceptíveis sintetizam níveis mais altos de leucotrienos que animais resistentes e este mediador lipídico pode ser associado à ativação precoce de macrófagos e maior carga fúngica, tanto in vivo como in vitro (Ribeiro, 2004). A elevada síntese de NO por camundongos susceptíveis leva à produção diminuída de TNF- $\alpha$ e infecções mais graves (Nascimento et al., 2002, Bernardino, 2006). Assim, todos estes dados associam-se àqueles obtidos no presente trabalho e demonstram que a resposta imune pode causar danos ao hospedeiro, levando, em algumas situações, à menor sobrevida. 
Para melhor compreender os fenômenos observados com os animais CD28KO e seu grupo controle, realizamos a análise histopatológica do pulmão em todos os períodos de infecção estudados. Verificamos que os animais CD28KO apresentavam formação de granulomas epitelióides, quando comparados ao seu grupo controle, em fases mais tardias da doença (décima semana em diante). Os animais controle, entretanto, já à segunda semana pós-infecção organizavam granulomas epitelióides (sem necrose supurativa central) que parecem ser eficazes quanto ao controle do crescimento fúngico pois o número dos mesmos não aumenta no pulmão e não se observa disseminação evidente para o fígado. Essa eficiência da resposta imune no controle do crescimento do $P$. brasiliensis nas lesões é bastante evidente na análise feita nos animais remanescentes dos experimentos de mortalidade. Há enorme diferença na carga fúngica dos pulmões e no fígado entre animais CD28KO e seus controle normais. Assim, a resposta imune de animais controle (WT) é capaz de controlar o crescimento fúngico, exercer atividade efetora de "clearance" do patógeno, fato este que não se observa com animais CD28KO. Fato interessante, entretanto, foi observado nos pulmões de camundongos CD28-normais aos 365 dias pós-infecção. Há a permanência de patologia tecidual e inflamação residual, apesar de total ausência de patógeno. Desta maneira, é tentador fazer algumas especulações para tentar correlacionar a maior mortalidade dos animais controle e os achados histopatológicos. Talvez os granulomas observados na décima semana pós-infecção nos camundongos CD28KO estariam impedindo a disseminação, mas não estariam matando os fungos das lesões. Por outro lado, o processo inflamatório observado nos camundongos controle seria responsável pela eliminação do fungo, devido à sua eficiente atividade efetora (macrófagos e leucócitos, polimorfonucleares ativados, linfócitos T citotóxicos, por exemplo). No conjunto, a análise histopatológica demonstra que camundongos $\mathrm{CD} 28 \mathrm{KO}$ desenvolvem uma infecção progressiva com relação ao número de fungos nas lesões, enquanto que camundongos CD28 normais apresentam uma infecção regressiva, com controle da morfologia das lesões e da carga fúngica desde a segunda semana de infecção. De alguma maneira ainda não definida, a ativação exacerbada do sistema imune, entretanto, levaria à morte dos animais controle. Como nos animais CD28-normais haveria tanto a ativação da resposta imune efetora como reguladora (Treg), a ação do TGF- $\beta$ ou outros mediadores anti-inflamatórios poderia causar ativação de fibroblastos, síntese de colágeno e 
subseqüente fibrose pulmonar. Apesar de ser apenas uma hipótese que precisa ser abordada experimentalmente, este tipo de patologia tem sido descrita na PCM-humana e é a maior causa de deficiência funcional e mortalidade dos pacientes (Franco et al., 1993). Por outro lado, a formação de granuloma tardio e uma ativação de resposta imune celular deficiente, porém existente, estariam impedindo a morte dos animais CD28KO. Esta interpretação, entretanto, necessita de novas abordagens experimentais para ser confirmada, ou não.

Sabe-se que a via pela qual o antígeno ou patógeno atinge o hospedeiro causa profunda diferença na subseqüente resposta imune que se desenvolve. A via s.c. induz forte imunidade celular e processos infecciosos fúngicos menos graves (Cox et al., 1988). Assim, o processo de imunização pela via s.c. poderia ocasionar na PCM diminuição da taxa de mortalidade, cargas fúngicas menores e reações de HTT persistentes. De fato, este fenômeno foi observado por Taborda (1998) e colaboradores onde a via s.c. foi utilizada em protocolo de vacinação com adjuvantes adicionados à gp43 (antígeno imunodominante do $P$. brasiliensis) atingindo proteção parcial.

Em nosso modelo experimental, Arruda et al. (2007) demonstraram que após imunização pela via s.c. e posterior desafio pela via i.p. com P. brasiliensis, camundongos B10.A apresentavam diminuição da carga fúngica no pulmão e fígado além de apresentarem aumento na produção de quase todos os anticorpos, exceto IgA, e aumento das citocinas IL-2 e IFN- $\gamma$ quando comparados com os animais somente infectados pela via i.p.. Por outro lado, quando animais B10.A foram imunizados pela via s.c., mas posteriormente desafiados pela via intravenosa (i.v.) observou-se doença mais grave, com aumento da mortalidade quando comparada àquela de animais controle desafiados somente pela via i.v. Este trabalho demonstrou que vários fatores podem influenciar na imunidade adquirida desenvolvida pelos hospedeiros infectados com o $P$. brasiliensis e, mais importante, que num único padrão genético um processo vacinante pode aumentar a proteção via imunidade celular ou causar doença exacerbada.

Em outro trabalho, também realizado em nosso laboratório (Arruda et al., 2007), verificou-se que a pré-imunização subcutâne conferia proteção esterilizante a camundongos 
susceptíveis, mas não alterava o curso da doença de camundongos resistentes. Experimentos in vivo demonstraram que a imunoproteção era de longa duração, associada a permanência de altos níveis de imunidade celular e era mediada pela ação sinérgica de linfócitos T $\mathrm{CD} 4^{+}, \mathrm{T} \mathrm{CD} 8^{+}$, IFN- $\gamma$ e IL-12.

Baseados nestes fatos resolvemos estudar o fenômeno de imunoproteção em camundongos deficientes para a molécula CD28 e seus pares normais. Assim, analisamos a gravidade da doença nos camundongos CD28KO e controle (WT) após imunização pela via s.c. e subseqüente desafio pela via i.t. com um milhão de fungos. Verificamos que tanto os camundongos CD28KO como os controle pré-imunizados pela via s.c. apresentavam diminuição significante da carga fúngica do pulmão quando comparado com os grupos de animais não imunizados. Além disso, a diferença entre o número de fungos recuperados dos animais CD28KO imunizados e não imunizado foi semelhante à diferença observada entre os mesmos grupos de camundongos controle (cerca de $2,5 \log _{10}$ ). É digno de nota também, o maior controle do crescimento fúngico no fígado dos animais CD28-deficientes pré-imunizados. Tal fato não pôde, entretanto, ser observado nos animais controle talvez devido ao menor número de fungos (ou resposta imune eficiente) presente neste órgão. O "clearance" fúngico exacerbado observado nos animais pré-imunizados demonstra que tanto animais CD28KO como CD28-normais desenvolvem memória imunológica que se traduz em mecanismos efetores capazes de controlar com eficiência o crescimento do P. brasiliensis. Desta maneira, na ausência da molécula coestimulatória CD28, outras moléculas com função equivalente (ICOS, LFA-1, VLA-4), tenham contribuído para o desenvolvimento da imunidade que resulta em infecção secundária menos grave.

A deficiência da resposta imune primária de camundongos CD28KO pode ter sido potenciada pela ausência desta molécula, mas deve ter ocorrido também a expansão deficientes de células Tregulatórias. Assim, a resposta imune induzida na primo infecção, independente de CD28, mas induzida por outras moléculas co-estimulatórias, seria suficiente para num desafio subseqüente controlar eficientemente o crescimento do patógeno. Deve-se também levar em consideração que as células $\mathrm{T}$ de memória dependem mais da sinalização via ICOS do que de CD28 para a sua ativação (Marks et al., 2007). Assim, a resposta imune secundária, apesar de não 
tão desenvolvida como nos animais controle, na ausência da expansão de Tregulatórias, levaria a fenômenos imunoprotetores equivalentes àqueles observados nos camundongos CD28-normais.

Camundongos CD28KO, tanto os pré-imunizados como os não imunizados têm a produção de IgG muito diminuída quando comparada à dos animais CD28-normais. A IgA, assim com a IgG2a aparecem em níveis menores nos animais controle pré-imunizados. Esse achado poderia ser atribuído à menor carga fúngica decorrente da pré-infecção. Nos camundongos CD28-deficientes não observamos diferenças significantes em nenhum dos isótipos estudados. Confirmou-se, entretanto, a baixa produção de $\operatorname{IgG}$ total, IgG1, IgG2a e $\operatorname{IgG} 2 b$, tanto nos camundongos pré-imunizados como naqueles somente infectados pela via i.t. Assim não pudemos observar níveis elevados de anticorpos, característicos da memória imunológica, fato este que pode ser atribuído ao tempo decorrido entre o desafio e o sacrifício dos animais (8 semanas). Neste período, tanto os animais CD28KO como os controle já haviam eficientemente controlado a carga fúngica, provavelmente diminuindo o estímulo para os linfócitos $\mathrm{B}$. Realmente, este fato já havia sido observado por Arruda e colaboradores (2007). A ausência de títulos mais elevados em animais $\mathrm{CD} 28 \mathrm{KO}$ deve, entretanto, ser primariamente atribuída à deficiente resposta T-dependente.

Realizamos também a dosagem de citocinas no pulmão e fígado dos camundongos imunizados e não imunizados. A citocina TGF- $\beta$ apresentou-se aumentada no sobrenadante de pulmão e fígado dos camundongos CD28KO imunizados quando comparado com camundongos CD28KO não imunizados. Esta citocina, apesar de ser conhecida como supressora de várias atividades da resposta imune (Gorelik \& Flavell, 2002), é associada a imunoproteção em certas doenças infecciosas. Um trabalho realizado com $C$. albicans demonstrou que o TGF- $\beta$ é necessário para a indução de resposta imunológica com padrão Th1 e que aumentava a resistência dos animais contra o fungo (Spaccapelo et al., 1995). Verificou-se também que o TGF- $\beta$ era necessário para potencializar o desenvolvimento da resistência adquirida e que sua administração poderia atrasar a progressão da doença letal de camundongos susceptíveis. No nosso trabalho, o aumento da citocina TGF- $\beta$ esteve associado à imunoproteção desenvolvida por camundongos CD28KO imunizados. É interessante, entretanto, que não observamos produção de IgG2b por camundongos CD28KO, fossem eles pré-imunizados ou não pela via s.c. Sabe-se que este isótipo 
DISCUSSÃO

é regulado pelo TGF- $\beta$ que se mostrou aumentado no fígado de animais CD28KO imunizados. O defeito co-estimulatório devido à ausência de CD28, entretanto, deve sobrepujar o efeito do TGF$\beta$ no "switch" para o isótipo IgG2b. Assim, sem a cooperação adequada entre células T e B não haveria a oportunidade da ação do TGF- $\beta$ causando a mudança de classe de anticorpo.

Os nossos dados demonstram que a molécula CD28 é importante para controlar o crescimento fúngico, mas a sua deficiência não resulta em ausência de memória imunológica e imunoproteção. Fenômeno contrário pôde ser observado nos estudos com $P$. chabaudi onde após o desafio secundário com o parasita, não houve eliminação facilitada do protozoário pelos animais CD28KO, sugerindo que a sinalização por este co-receptor é necessária para desenvolver-se imunidade secundária protetora ao $P$. chabaudi (Elias et al., 2005). Os resultados opostos com P. chabaudi e P. brasiliensis podem ser explicados pela natureza diversa destes dois patógenos. Enquanto que a imunoproteção contra o protozoário é, ao menos parcialmente, dependente da produção de anticorpos, na PCM a imunoproteção independe dos anticorpos e parece ser mediada pelas células $\mathrm{T} \mathrm{CD}^{+}$e $\mathrm{T} \mathrm{CD} 8^{+}$com a colaboração de IFN- $\gamma$ e da IL-12 (Arruda et al., 2007).

Nossos resultados indicam também que camundongos CD28KO estão habilitados a fazer resposta imune celular utilizando, talvez, outro par de moléculas co-estimulatórias, como por exemplo, ICOS e ICOS-L. Este outro par de moléculas co-estimulatórias é importante na regulação de produção de citocinas por células $\mathrm{T}$ ativadas, e nas respostas de células Th2 de memória a sinalização mediada por este par dispensa a interação via CD28 (Sharpe et al., 2002, Iezzi et al., 1998).

Trabalho bastante recente estudou a participação das moléculas CD28 e ICOS na infecção genital por Chlamidia trachomalis. Verificou-se que a sinalização celular via CD28 é crítica e necessária para a indução da resposta imune Th1 que protege desta infecção bacteriana. Por outro lado, ICOS parece ser dispensável e pode ter um efeito repressor sobre o desenvolvimento da imunidade Th1 através da indução de linfócitos Th2, secreção de IL-10 e expansão de linfócitos $\mathrm{T}$ regulatórios $\left(\mathrm{Foxp}^{+}\right.$). Tanto os camundongos ICOS${ }^{-}$como CD28-deficientes mostraram-se mal produtores de anticorpos e reforçaram os achados prévios demonstrando que a imunoproteção contra o C. trachomalis é independente de anticorpos (Marks et al., 2007). 
Outros estudos têm relatado a importância das moléculas co-estimulatórias na resposta imune dos hospedeiros contra patógenos intracelulares (Compton \& Farrell 2002, Mittrucker et al., 1999, Mittrucker et al., 2002). Assim, pôde-se verificar que tanto a estimulação por CD28 assim como a dose do protozoário determinavam a susceptibilidade de camundongos $\mathrm{BALB} / \mathrm{c}$ à infecção pela Leishmania major (Compton \& Farrell 2002). Estudos com Salmonella typhimurium (Mittrucker et al., 1999) e com Listeria monocytogenes (Mittrucker et al., 2002) enfatizaram a importância das moléculas CD28 e ICOS, respectivamente, na proteção dos hospedeiros. Estudos complementares com Salmonella sp demonstraram que a resposta imune protetora em animais ICOS-deficientes é tardia devido à produção deficiente de anticorpos e de linfócitos de fenótipos $\mathrm{T} \mathrm{CD}^{+}$e Th1 (Tang et al., 2003).

Apesar de não possuirmos dados experimentais que esclareçam os mecanismos dos fenômenos imunológicos aqui descritos, tentaremos apresentar uma hipótese que unifique os nossos principais achados. Pode-se supor que na infecção primária pelo $P$. brasiliensis camundongos CD28KO desenvolvam resposta celular deficiente, com baixa atividade efetora e que possibilita o crescimento fúngico. Há, entretanto, o desenvolvimento de resposta imune celular que, embora tardiamente, é capaz de circunscrever o fungo através de granulomas epitelióides. A baixa síntese de citocinas pró-inflamatórias, entretanto, não leva à morte dos fungos nas lesões que então, permanecem nos tecidos. Por outro lado, esta resposta imune deficiente, induzida por outras moléculas co-estimulatórias que não $\mathrm{CD} 28$, faz-se associada à ausência de células Tregulatórias, que não se expandem devido à sua dependência de CD28 e de IL-2. Na resposta imune secundária células de memória ICOS-dependentes, na ausência de células Tregulatórias, conseguiriam controlar o crescimento fúngico com eficiência equivalente à observada nos camundongos CD28-normais. Além disso, os estudos com animais CD28deficientes indicaram que a presença do $P$. brasiliensis em lesões granulomatosas organizadas não é deletéria para os hospedeiros.

Em contrapartida, camundongos CD28-normais desenvolveriam resposta imune precoce com expansão de células efetoras e citocinas pró-inflamatórias que conseguiriam controlar o crescimento fúngico. Haveria, entretanto, a concomitante expansão de células T regulatórias que 
DISCUSSÃO

controlariam a inflamação excessiva, levando a um processo inflamatório regressivo. Na infecção secundária seria observado o efeito protetor das células $\mathrm{T}$ de memória reguladas, porém, pelas células T regulatórias.

Fato difícil de explicar é a maior mortalidade dos animais CD28-normais quando comparado aos deficientes. Pode-se supor que a resposta imune eficiente para o "clearance" do fungo induz, concomitantemente, processos desativadores da resposta. A presença de células produtoras de TGF- $\beta$ levaria à ativação de fibroblastos e outras células pulmonares causando a deposição de colágeno e outras proteínas da matriz extracelular que resultaria em processo fibrótico que, cronicamente, levaria à morte do hospedeiro. Neste contexto, a fibrose não teria sido observada e não seria marcante nos camundongos sobreviventes, mas teria causado a morte dos outros animais usados no experimento de mortalidade.

Em conclusão, nosso trabalho demonstrou pela primeira vez que a molécula CD28 exerce um papel regulatório na imunidade ao $P$. brasiliensis e a sua deficiência conduz a um processo infeccioso mais grave, porém não letal, associado a uma diminuição na produção de anticorpos e citocinas, provavelmente pela ativação deficiente de células T. Além disso, nossos estudos demonstraram que a carga fúngica elevada, na ausência da imunidade adaptativa efetora, não ocasiona a morte do hospedeiro infectado pelo P. brasiliensis, indicando claramente o duplo papel exercido pela resposta imune, que pode tanto proteger, como também induzir patologia com conseqüência grave na sobrevida dos hospedeiros.

Finalmente, nossos estudos também indicaram que a ausência da molécula CD28 não impede o desenvolvimento de memória imunológica contra a infecção pelo $P$. brasiliensis, uma vez que camundongos CD28KO são capazes de controlar uma infecção secundária pelo fungo. 


\section{CONCLUSÕES}




\section{CONCLUSÕES}

$\checkmark$ O presente trabalho demonstrou que a molécula co-estimulatória CD28 é importante para o desenvolvimento da imunidade adaptativa contra o $P$. brasiliensis.

Atua nos mecanismos de "clearance" do fungo nos pulmões e regula a produção de anticorpos e citocinas.

$\checkmark$ Na infecção primária, induz a organização precoce das lesões pulmonares, porém a sua presença está associada à menor sobrevida dos camundongos infectados.

$\checkmark$ A ausência da molécula CD28 não acarreta a perda da memória imunológica ao $P$. brasiliensis, uma vez que camundongos CD28-deficientes têm resposta imune protetora equivalente à dos camundongos CD28-normais. 
REFERÊNCIAS BIBLIOGRÁFICAS 


\section{REFERÊNCIAS BIBLIOGRÁFICAS}

ALBORNOZ, M.B. Isolation of Paracoccidioides brasiliensis from rural soil in Venezuela. Sabouraudia, v. 9, p. 248-253, 1971.

ARANGO, M., \& YARZABAL, L. T-cell dysfunction and hyperimmunoglobulinemia E in Paracoccidioidomycosis. Mycopathologia., v. 79, p. 115-123, 1982.

ARISTIZABAL, B.H.; CLEMONS, K.V.; STEVENS, D.A.; RESTREPO, A. Morphological transition of Paracoccidioides brasiliensis conidia to yeast cells: in vivo inhibition in females. Infect. Immun., v. 66, p. 5587-5591, 1998.

ARRUDA, C., KASHINO, S.S., FAZIOLI, R.A., CALICH, V.L.G. A primary subcutaneous infection with Paracoccidioides brasiliensis leads to immunoprotection or exacerbated disease depending on the route of challenge. Microbes Infect. v.9, p.308-316, 2007.

ARRUDA, C., VAZ, C.A., CALICH, V.L.G. Aseptic cure of pulmonary paracoccidioidomycosis can be achieved after a previous subcutaneous immunization of susceptible but not resistant mice. Microbes Infect. v.9, p.704-713, 2007.

ARRUDA, C.; FRANCO, M.F.; KASHINO, S.; NASCIMENTO, F.R.F.; FAZIOLI, R.A.; VAZ, C.A.C.; RUSSO, M.; CALICH, V.L.G. Interleukin-12 protects mice against disseminated infection caused by Paracoccidioides brasiliensis but enhances pulmonary inflammation. Clinical Immunol.v, 103, p. 185-195, 2002.

ARRUDA, C.; VALENTE-FERREIRA, R. C.; PINA, A.; KASHINO, S. S.; FAZIOLI, R. A.; VAZ, C. A. C.; FRANCO, M. F.; CALICH, V. L. G. Dual role of IL-4 in pulmonary Paracoccidioidomycosis: Endogenous IL-4 can induce protection or exacerbation of disease depending on the host genetic pattern. Infect. Immun., v.72, p. 3932-3940, 2004. 


\section{REFERÊNCIAS BIBLIOGRÁFICAS}

BAGAGLI, E.; SANO, A.; COELHO, K.I.; ALQUATI, S.; MIYAJI, M.; DE CAMARGO, Z.P.; GOMES, G.M.; FRANCO, M.; MONTENEGRO, M.R. Isolation of Paracoccidioides brasiliensis from armadillos (Dasypus noveminctus) captured in an endemic area of paracoccidioidomycosis. Am. J. Trop. Med. Hyg., v. 58 (4), p. 505-512, 1998.

BAIDA, H.B.; BISELLI, P.J.C.; JUVENALE, M.; DEL NEGRO, G.; MENDES-GIANNINI, M.J.S.; DUARTE, A.J.S.; BENARD, G. Differential antibody isotype expression to the major Paracoccidioides brasiliensis antigen in juvenile and adult form paracoccidioidomycosis. Microbes Infect., v. 1, p. 273-278, 1999.

BECK, J.M.; BLACKMON, M.B.; ROSE, C.M.; KIMZEY, S.L.; PRESTON, A.M.; \& GREEN, J.M. T cell costimulatory molecule function determines susceptibility to infection with pneumocystis carinii in mice. J. Immunol., v. 171, p. 1969-1977, 2003.

BENARD, G.; MENDES-GIANNINI, M.J.; JUVENALE, M.; MIRANDA, E.T.; DUARTE, A.J. Immunosuppression in Paracoccidioidomycosis: $\mathrm{T}$ cell hyporesponsiveness to two Paracoccidioides brasiliensis glycoproteins that elicit strong humoral immune response. J Infect Dis., v. 175(5), p. 1263-1267, 1997.

BERLINER, M.D.; RECA, M.E. Vital staining of Histoplasma capsulatum with Janus Green B. Sabouraudia, v. 5, p. 26-29, 1966.

BERNARDINO,S. (Dissertação). Paracoccidioidomicose pulmonar em camundongos geneticamente deficientes da enzima óxido nítrico sintase-induzida (iNOS). São Paulo, São Paulo: Universidade de São Paulo, 2006, 82 pp. 


\section{REFERÊNCIAS BIBLIOGRÁFICAS}

BIAGIONI, L.; SOUZA, M.J.; CHAMMA, L.G.; MENDES, R.P.; MARQUES, S.A.; MOTA, N.G.; FRANCO, M. Serology of Paracoccidioidomycosis. II. Correlation between class-specific antibodies and clinical forms of the disease. Trans R Soc Trop Med Hyg., v. 78(5), p. 617-621, 1984.

BLOTTA, M.H.; MAMONI, R.L.; OLIVEIRA, S.J.; NOUER, S.A.; PAPAIORDANOU, P.M.; GOVEIA, A.; CAMARGO, Z.P. Endemic regions of Paracoccidioimomycosis in Brasil: clinical and epidemiologic study of 584 casas in the southeast region. Am. J. Med. Hyg., v. 61(3), p. 390-394, 1999.

BOCCA, A. L.; HAYASSHI, E. E.; PINHEIRO, A. G.; FURIANETTO, A. B.; CAMPANELLI, A. P.; CUNHA, F. Q.; FIGUEIREDO, F. Treatment of Paracoccidioides brasiliensis infected mice with a nitric oxide inhibitor prevents the failure of cell-mediated immune response. $\mathbf{J}$. Immunol., v. 161, p. 3056-3063; 1998.

BOPP, C. Algumas considerações sobre a micose de Lutz no Rio Grande do Sul. Na. Fac. Med., v. 15, p. 97-123, 1955.

BOUSSIOTIS, V.A.; FREEMAN, G.J.; GRAY, G.; GRIVVEN, J.; \& NADLER, L.M. B7 but not intercellular adhesion molecule-1 costimulation prevents the induction of human alloantigenspecific tolerance. J. Exp. Med. 5: 1753-1763, 1993.

BRETSCHER, P. The two-signal model of lymphocyte activation twenty-one years later. Immunol. Today, v. 13, p. 74-76, 1982.

BROWN, D.R.; GREEN, J.M.; MOSKOWITZ, N.H.; DAVIS, M.; THOMPSON, C.B.; \& REINER, S.L. Limited role of CD28-mediated signals in T helper subset differentiation. J. Exp. Med., v. 184, p. 803-810, 1996. 


\section{REFERÊNCIAS BIBLIOGRÁFICAS}

BRUMMER, E. Interaction of Paracoccidioides brasiliensis with host defense cells. In M. Franco, C.S. Lacaz, A. Restrepo, and G. Del Negro (eds), Paracoccidioidomycosis. CRC Press, Boca Raton, Florida, p. 213-224, 1994.

BRUMMER, E.; CASTANEDA, E.; RESTREPO, A. Paracoccidioidomycosis an update. Clin. Microbiol. Rev., v. 6, p. 89-96, 1993.

BURGER, E.; VAZ, C.C.; SANO, A.; CALICH, V.L.G.; SINGER-VERMES, L.M.; XIDIEH, C.F.; KASHINO, S.S.; NISHIMURA, K.; \& MIYAJI, M. Paracoccidioides brasiliensis infection in nude mice: studies with isolates differing in virulence and definition of their T cell-dependent and T cell-independent components. Am. J. Trop. Med. Hyg., v. 55, p. 391-398, 1996.

CACERE, C.R.; ROMANO, C.C.; MENDES GIANNINI, M.J.; DUARTE, A.J.; BENARD, G. The role of apoptosis in the antigen-specific $\mathrm{T}$ cell hyporesponsiveness of Paracoccidioidomycosis patients.Clin. Immunol., v. 105(2), p. 215-222, 2002.

CALICH, V.L.G., COSTA, T.A., FELONATO, M., ARRUDA, C., BERNARDINO, S., LOURES, F.V., RIBEIRO, L.R.R., VALENTE-FERREIRA, R.C., PINA, A. Innate Immunity to Paracoccidioides brasiliensis. Mycophatology. (in press), 2007.

CALICH, V.L.G.; BLOTTA, M.H.S.L. Pulmonary Paracoccidioidomycosis. In Fungal Immunology: From an Organ Perspective. P. L. Fidel, and G. B. Huffnagle, eds. Springer, New York, NY. 201-228, 2005.

CALICH, V.L.G.; KASHINO, S.S. Cytokines produced by susceptible and resistant mice in the course of Paracoccidioides brasiliensis infection. Braz. J. Med. Biol. Res., v. 31, p. 615-623, 1998. 


\section{REFERÊNCIAS BIBLIOGRÁFICAS}

CALICH, V.L.G.; VAZ, C.; BURGER, E. Immunogenetics in Paracoccidioidomycosis. In: FRANCO, M.F.; LACAZ, C.S.; RESTREPO, A.; DEL NEGRO, G. (ed), Paracoccidioidomycosis. CRC Press, Boca Raton, Fla., p. 151-166, 1994.

CAMARGO, Z.P.; TABORDA, C.P.; RODRIGUES, E.G.; TRAVASSOS, L.R. The use of cellfree antigens of Paracoccidioides brasiliensis in serological tests. J Med Vet Mycol., v. 29(1), p. 31-38, 1991.

CAMPANELli, A.P.; MARTINS, G.A.; SOUTO, J.T.; PEREIRA, M.S.; LIVONESI, M.C.; MARTINEZ, R.; SILVA, J.S. Fas-Fas ligand (CD95-CD95L) and cytotoxic T lymphocyte antigen-4 engagement mediate $\mathrm{T}$ cell unresponsives in patients with paracoccidioidomycosis. $\mathbf{J}$. Infect. Dis., v. 187, p. 1496-1505, 2003.

CANO, L.E.; KASHINO, S.S.; ARRUDA, C.; ANDRÉ, D.; XIDIEH, C.F.; SINGER-VERMES, L.M.; VAZ, C.A.C.; BURGER, E.; CALICH, V.L.G. Protective role of gamma interferon in experimental pulmonary Paracoccidioidomycosis. Infect. Immun., v. 66, p. 800-806, 1998.

CANO, L.E.; SINGER-VERMES, L.M.; COSTA, T.A.; MENGEL, J.O.; XIDIEH, C.F.; ARRUDA, C.; ANDRÉ, D.C.; VAZ, C.A.C.; BURGER, E.; CALICH, V.L.G. Depletion of CD8 ${ }^{+}$ $\mathrm{T}$ cells in vivo impairs host defense of mice resistant and susceptible to pulmonary Paracoccidioidomycosis. Infection and Immunity, v. 69, p. 352-359, 2000.

CANO, L.E.; SINGER-VERMES, L.M.; VAZ, C.C.; RUSSO, M.; \& CALICH, V.L.G. Pulmonary Paracoccidioidomycosis in resistant and susceptible mice: relationship among progression of the infection, bronchoalveolar cell activation, cellular immune response, and specific isotype patterns. Infect. Immun., v. 63, p. 1777-1783, 1995.

CARSON, F.L., MARTIN, J.H., LYNN, J.A. Formalin fization for electron microscopy: areevaluation. Am. J. Clin. Pathol. v.59, p.363-373, 1973. 


\section{REFERÊNCIAS BIBLIOGRÁFICAS}

CASTAÑEDA, E.; BRUMMER, E.; PAPPAGIANIS, D.; \& STEVENS, D.A. Impairment of cellular but not humoral immune response in chronic pulmonary and disseminated Paracoccidioidomycosis in mice. Infect. Immun., v. 56, p. 1771-1777, 1988.

CAVASSANI, K.A. Participação das células T-reguladoras no controle da resposta imune durante a Paracoccidioidomicose humana. Tese de Doutorado, Faculdade de Medicina, USP, Ribeirão Preto, Brasil, 2006.

COMPTON, H.L., FARRELL, J.P. CD28 costimulation and parasite dose combine to influence the susceptibility of BALB/c mice to infection with Leishmania major. J. Innunol. v.168, p.1302-1308, 2002.

COUPER, K.N.; ROBERTS, C.W.; BROMBACHER, F.; ALEXANDER, J.; \& JOHNSON, L.L. Toxoplasma gondii-specific immunoglobulin M limits parasite dissemination by preventing host cell invasion. Infect. Immun., v. 73, p. 8060-8068, 2005.

COUTINHO, Z.F.; SILVA, D.; LAZERA, M.; PETRI, V.; OLIVEIRA, R.M.; SABROZA, P.C.; WANKE, B. Paracoccidioidomycosis mortality in Brasil. Cad. Saúde Pública, v. 18, p. 14411454, 2002.

COX, R.A., KENNEL, W., BONCYK. L., MURPHY, J.W. Induction and expression of cellmediated immune responses in inbred mice infected with Coccidioides immitis. Infect. Immun. v.56, p.13-17, 1988.

CHAMBERS, C.A.; \& ALLISON, J.P. Costimulatory regulation of T cell function. Curr. Opin. Cell Biol., v. 11, p. 203-210, 1999. 


\section{REFERÊNCIAS BIBLIOGRÁFICAS}

ChiARElla, A.P., ARrudA, C., PINA, A., COSTA, T.A., FERrEIRA, R.C., CAliCH, V.L.G. The relative importance of $\mathrm{CD}^{+}$and $\mathrm{CD}^{+} \mathrm{T}$ cells in immunity to pulmonary paracoccidioidomycosis. Microbes Infect. V.9, p.1078-1088, 2007.

DAMLE, N.K., KLUSSMAN, K., LEYTZE, G., OCHS, H.D., ARUFFO, A., LINSLEY, P.S. AND LEDBETTER, J.A. Costimulation via vascular cell adhesion molecule-1 induces in T cells increased responsiveness to the CD28 counter-receptor B7. Cellular Immunol. v.148, p.144$156,1993$.

DE BRITO, T.; FURTADO, J.S.; CASTRO, R.M.; MANINI, M. Intraepithelial parasitism as an infection mechanism in human Paracoccidioidomycosis (South American blastomycosis). Virchows Arch. A. Pathol. Anat., v. 361 (2), p. 129-138, 1973.

DEEPE, G.S.JR.; ROMANI, L.; CALICH, V.L.G.; HUFFNAGLE, G.; ARRUDA, C.; MOLINARI-MADLUM, E.E.; PERFECT, JR. Knockout mice as experimental models of virulence. Med. Mycol., v. 38, p. 87-98, 2000.

DING, A.H.; NATHAN, C.F.; STUEHR, D.J. Release of reactive nitrogen intermediates and reactive oxygen intermediates from mouse peritoneal macrophages. Comparison of activating cytokines and evidence for independent production. J Immunol., v. 141(7), p. 2407-2412, 1988.

ELIAS, R.M.; SARDINHA, L.R.; BASTOS, K.R.; ZAGO, C.A.; DA SILVA, A.P.; ALVAREZ, J.M.; \& LIMA, M.R. Role of CD28 in polyclonal and specific T and B cell responses required for protection against blood stage malaria. J. Immunol., v. 174, p. 790-799, 2005.

FAVA NETTO, C. Estudos quantitativos sobre a fixação do complemento na blastomicose sulamericana, com antígeno polissacarídico, Arq. Cir. Clin. Exp. São Paulo, v. 18, p. 197-254, 1955. 


\section{REFERÊNCIAS BIBLIOGRÁFICAS}

FAVA NETTO, C.; RAPHAEL, A. A reação intradérmica com polissacáride do Paracoccidioides brasiliensis, na blastomicose sul-americana. Ver. Inst. Med. Trop. São Paulo, v. 3, p. 161-165, 1961.

FAZIOLI, R.A. Paracoccidioidomicose experimental murina. Estudo da proliferação e da contribuição de células $\mathrm{T} \mathrm{CD}^{+}$e $\mathrm{T} \mathrm{CD}^{+}$na resposta imune de camundongos resistentes e susceptíveis. Tese de Doutorado, ICB, USP, 1997.

FERREIRA, M.S.; FREITAS, L.H.; LACAZ, C.S.; DEL NEGRO, G.M.B.; De MELO, N.T.; GARCIA, N.M.; De ASSIS, C.M.; SALEBIAN, A.; HEINS-VACCARI, E.M. Isolation and characterization of a Paracoccidioides brasiliensis strain from a dogfood probaba contaminated with soil in Uberlandia, Brazil. J. Med. Vet. Mycol., v. 28, p. 253-256, 1990.

FRANCO, M.F. Host parasite relationship in Paracoccidioidomycosis. J. Med. Vet. Mycol., v. 25, p. $5-18,1987$.

FRANCO, M.F.; MEDNDES, R.P.; MOSCARDI-BACCHI, M.; REZKALLAH-WASSO, M.T.; MOnTEnegro, M.R. Paracoccidioidomycosis. Bailliéres Clin. Trop. Med. Comum. Dis., v. 4, p. 185-220, 1989.

FRANCO, M.F.; PERAÇOLI, M.T.S.; SOARES, A.M.; MONTENEGRO, M.R.; MENDES, R.P.; MEIRA, D.A. Hot-parasite relationship in Paracoccidioidomycosis. Curr. Trop. Med. Mycol., v. 5, p. 115-149, 1993.

GAGLIA, J. L.; GREENFIELD, E.A.; MATTOO, A.; SHARPE, A. H.; FREEMAN, G .J.; \& KUCHRROO, V .K. Intercellular adhesion molecule 1 is critical for activation of CD28-deficient T cells. J. Immunol., v. 165, p. 6091-6098, 2000. 


\section{REFERÊNCIAS BIBLIOGRÁFICAS}

GARCIA, N.M.; DEL NEGRO, G.M.B.; HEINS-VACCARI, E.M.; MELO, N.T.; ASSIS, C.M.; LACAZ, C.S. Paracoccidioides brasiliensis, nova amostra isolada de fezes de um pingüim (Pygoscelis adeliae). Rev. Inst. Med. Trop. São Paulo, v. 35, p. 227-235, 1993.

GAUSE, W.C.; CHEN, S.J.; GREENWALD, R.J.; HALVORSON, M.J.; LU, P.; ZHOU, X.D.; MORRIS, S.C.; LEE, K.P.; JUNE, C.H.; FINKELMAN, F.D.; URBAN, J.F.; \& ABE, R. CD28 dependence of $\mathrm{T}$ cell differentiation to IL-4 production varies with the particular type 2 immune response. J. Immunol., v. 158, p. 4082-4087, 1997.

GONZALEZ, A.W. DE GREGORI, VELZ, D., RESTREPO, A. AND CANO, L.E. Nitric oxide participation in the fungicidal mechanism of gamma inteferon activared murine macrophages against Paracoccidioides brasiliensis. Infect. Immun. v. 68, p.2546-2552, 2000.

GONZALEZ, A.; RESTREPO, A.; CANO, L.E. Role of iron in the nitric oxide-mediated fungicidal mechanism of IFN-gamma-activated murine macrophages against Paracoccidioides brasiliensis conidia. Rev Inst Med Trop Sao Paulo, v. 49(1), p. 11-16, 2007.

GONZALEZ-OCHOA, A. Advances in the treatment of fungus infections. Gac. Med. Mex., v. 104 (6), p. 450-456, 1972.

GORELIK, L., FLAVELL, R.A. Transforming growth factor-beta in T-cell biology. Nat. Rev. Immunol. v.2, p.46-53, 2002.

HAGERTY, D.T. Intercellular adhesion molecule-1 is necessary but not sufficient to activate $\mathrm{CD}^{+} \mathrm{T}$ cells: discovery of a novel costimulator on kidney tubule cells. J. Immunol., v. 156, p. 3652-3659, 1996. 


\section{REFERÊNCIAS BIBLIOGRÁFICAS}

HIBBS, J.B. JR.; VAVRIN, Z.; TAINTOR, R.R. L-arginine is required for expression of the activated macrophage effector mechanism causing selective metabolic inhibition in target cells. $\mathbf{J}$ Immunol., v. 138(2), p. 550-565, 1987.

HONG, M.; ZHU, Q. Macrophages are activated by 17 beta-estradiol: possible permission role in endometriosis. Exp. Toxicol. Pathol., v. 55, p. 344-350, 2004.

HUTlOFF, A.; DITTRICH, A.M.; BEIER, K.C.; ELJASCHEWITSCH, B.; KRAFT, R.; ANAGNOSTOPOULOS, I.; KROCZEK, R.A. ICOS is an inducible T cell co-stimulator structurally and functionally related to CD28. Nature, v. 397, p. 263-266, 1999.

IEZZI, G.; KARJALAINEN, K.; \& LANZAVECCHIA, A. The duration of antigenic stimulation determines the fate of naive and effector T cells. Immunity, v. 8, p. 89-95, 1998.

JUNE, C.H; BLUESTONE, J.A; NADLER, L.M.; \& THOMPSON, C.B. The B7 and CD28 receptor families. Immunol. Today, v. 15, p. 321-331, 1994.

KARHAWI, A.S.; COLOMBO, A.L.; SALOMAO, R. Production of IFN-gamma is impaired in patients with paracoccidioidomycosis during active disease and is restored after clinical remission. Med Mycol., v. 38(3), p. 225-229, 2000.

KASHINO, S.S.; CALICH, V.L.G.; BURGER, E.; SINGER-VERMES, L.M. In vivo and in vitro characteristics of six Paracoccidioides brasiliensis strains. Mycopathologia, v. 92, p. 173-178, 1985. 


\section{REFERÊNCIAS BIBLIOGRÁFICAS}

KASHINO, S.S.; FAZIOLI, R.A.; CAFALLI-FAVATI, C.; MELONI-BRUNERI, L.H.; VAZ, C.A.; BURGER, E.; SINGER, L.M.; CALICH, V.L.G. Resistance to Paracoccidioides brasiliensis infection is linked to a preferential Th1 immune response, whereas susceptibility is associated with absence of IFN-gamma production.J. Interferon Cytokine Res., v.20, p. 89-97, 2000.

KASHINO, S.S.; FAZIOLI, R.A.; MOSCARDI-BACCHI, M.; FRANCO, M.; SINGERVERMES, L.M.; BURGER, E.; CALICH, V.L.G. Effect of macrophage blockade on the resistance of inbred mice to Paracoccidioides brasiliensis infection. Mycopathologia, v. 130(3), p. 131-140, 1995.

KASHINO, S.S.; SINGER-VERMES, L.M.; CALICH, V.L.G.; \& BURGER, E. Alterations in the pathogenicity of one Paracoccidioides brasiliensis isolate do not correlate with its in vitro growth. Mycopathologia, v. 111, p. 173-180, 1990.

LACAZ, C.S.; ZAMITH, V.A.; DEL NEGRO, G.; SIQUEIRA, A.M. Aspectos clínicos gerais. In: FRANCO, M.; LACAZ, C.S.; RESTREPO-MORENO, A.; DEL NEGRO, G. Paracoccidioimomicose, São Paulo, 1982.

LENSCHOW, D.J.; HEROLD, K.C.; RHEE, L.; PATEL, B.; KOONS, A.; QUIN, H.Y.; FUCHS, E.; SINGH, B.; THOMPSON, C.B.; \& BLUESTONR, J.A. CD28/B7 regulation of Th1 and Th2 subsets in the development of autoimmune diabetes. Immunity, v. 5, p. 285-293, 1996.

LIFE, P.; AUBRY, J.P.; ESTOPPEY, S.; SCHNURIGER, V.; \& BONNEFOY, J.Y. CD28 functions as an adhesion molecule and is involved in the regulation of human IgE synthesis. Eur. J. Immunol., v. 25, p. 333-339, 1995. 


\section{REFERÊNCIAS BIBLIOGRÁFICAS}

LIU, Y., AMARNATH, S., CHEN, W. Requirement of CD28 signalling in homeostasis survival of TGF- $\beta$ converted $\mathrm{CD} 4^{+} \mathrm{CD} 25^{+}$Tregs from thymic $\mathrm{CD} 4^{+} \mathrm{CD} 25^{-}$single positive $\mathrm{T}$ cells. Transplantation. v.82, p.953-964, 2006.

LIU, Y.; WENGER, R.H.; ZHAO, M.; \& NIELSEN, P.J. Distinct costimulatory molecules are required for the induction of effector and memory cytotoxic T lymphocytes. J. Exp. Med., v. 185, p. 251-261, 1997.

LOOSE, D.S., STOVER, E.P., RESTREPO, A., STEVENS, D.A., \& FELDMAN, D. Estradiol binds to a receptor-like cytosol protein and inhibits a biological response in Paracoccidioides brasiliensis. Proc. Natl. Acad. Sci. USA, v. 80, p. 7659-7663, 1983.

LUTZ, A. Uma mycose pseudococcidica localizada na bocca e observada no Brazil. Contribuição ao conhecimento das hyphoblastomicoses americanas. Brasil-Med., v. 22, p. 121-124, 1908.

MAMONI, R.L.; NOUER, R.A.M.S.; OLIVEIRA, S.A.; MUSATTI, C.C.; ROSSI, C.L.; CAMARGO, Z.P.; BLOTTA, M.H.S.L. Enhanced production of specific IgG4, IgE, IgA and TGF- $\beta$ in sera from patients with the juvenile form of Paracoccidioidomycosis. Med. Mycol., v. 40, p. 1-7, 2002.

MAMONI, R.L.; ROSSI, C.L.; CAMARGO, Z.P.; BLOTTA, M.H.S.L. Capture enzyme-linked immunosorbent assay to detect specific immunoglobulin $\mathrm{E}$ in sera of patients with Paracoccidioidomycosis. Am. J. Trop. Med. Hyg., v.65, p. 237-241, 2001.

MARKS, E., VEROLIN, M., STENSSON, A. AND LYCKE, N. Differential CD28 and inducible costimulatory molecule signaling requirements for protective $\mathrm{CD}^{+} \mathrm{T}$ cell mediated immunity against genital tract Chlamydia trachomatis infection. Infection and Immunity. v.75, p.46384647, 2007. 


\section{REFERÊNCIAS BIBLIOGRÁFICAS}

MARTINS, G.A.; CAMPANELLI, A.P.; SILVA, R.B.; TADOKORO, C.E.; RUSSO, M.; CUNHA, F.Q.; RIZZO, L.V.; SILVA, J.S. CD28 is required for T cell activation and IFNgamma production by $\mathrm{CD} 4+$ and $\mathrm{CD} 8+\mathrm{T}$ cells in response to Trypanosoma cruzi infection. Microbes Infect., v. 6, p. 1133-1144, 2004.

MATHUR, M.; HERRMANN, K.; QIN, Y.; GULMEN, F.; LI, X.; KRIMINS, R.; WEINSTOCK, J.; ELLIOTT, D.; BLUESTONE, J.A.; \& PADRID, P. CD28 interactions with either CD80 or CD86 are sufficient to induce allergic airway inflammation in mice. Am. $\mathbf{J}$.

Respir. Cell Mol. Biol., v. 21, p. 498-509, 1999.

McEWEN, J.G.; BEDOYA, V.; PTINO, M.M.; SALAZAR, M.E.; RESTREPO, A. Experimental murine Paracoccidiodomycosis induced by inhalation of conidia. J. Med. Vet. Mycol., v. 25, p.165-175, 1987.

McEWEN, J.G.; GARCIA, A.M.; ORTIZ, B.L.; BOTERO, S.; RESTREPO, A. In search of the natural habitat of Paracoccidioides brasiliensis. Arch. Med. Res., v. 26, p. 305-206, 1995.

McMICKING, J.D.; NORTH, R.J.; LACOURSE, R.; MUDGETT, J.S.; SHAH, S.K.; NATHAN, C.F. Identification of nitric oxide synthase as a protective locus against tuberculosis. Proc. Natl. Acad. Sci. U S A., v. 94(10), p. 5243-5248, 1997.

MENDES-GIANNINI, M.J.S.; DEL NEGRO, G.B.; SIQUEIRA, A.M. Serodiagnosis, In: FRANCO, M.; LACAZ, S.C.; RESTREPO, A.; DEL NEGRO, G. (ed) PARACOCCICIOIDOMYCOSIS CRC PRESS, INC, BOCA RATON, p. 345-363, 1984.

MITTRUCKER, H.W., KOHLER, A., MaAK, T.W, KAUFMANN, S.H. Critical role of CD28 in protective immunity against Salmonella typhimurium. J. Immunol. v.163, p.6769-6776, 1999. 


\section{REFERÊNCIAS BIBLIOGRÁFICAS}

MITTRUCKER, H.W., KURSAR, M., KOHLER, A., YANAGIHARA, D., YOSHINAGA, S.K., KAUFMANN, S.H. Inducible costimulator protein controls the protective $\mathrm{T}$ cell response against Listeria monocytogenes. J. Immunol. v.169, p.5813-5817, 2002.

MONTAGNOLI, C.; BACCI, A.; BOZZA, S.; GAZIANO, R.; MOSCI, P.; SHARPE, A.H.; \& ROMANI, L. B7/CD28-dependent $\mathrm{CD} 4{ }^{+} \mathrm{CD} 25^{+}$regulatory $\mathrm{T}$ cells are essential components of the memory-protective immunity to Candida albicans. J. Immunol., v. 169, p. 6298-6308, 2002.

MOSCARDI-BACCHI, M.; BRUMMER, E.; STEVENS, D.A. Support of Paracoccidioides brasiliensis multiplication by human monocytes or macrophages: inhibition by activates phagocytes. J. Med. Microbiol., v. 40, p. 159-164, 1994.

MOTA, N.G.; REZKALLAH-IWASSO, M.T.; PERACOLI, M.T.; AUDI, R.C.; MENDES, R.P.; MARCONDES, J.; MARQUES, S.A.; DILLON, N.L.; FRANCO, M.F. Correlation between cellmediated immunity and clinical forms of Paracoccidioidomycosis. Trans. R. Soc. Trop. Med. Hyg., v. 79(6), p. 765-772, 1985.

MUCHMORE, H.G., MICKOWN, B.A. \& MOHR, J.A. Una crediente campanã contra la Paracoccidioidomycosis. Efectos de las hormonas esteroides sobre la proliferacion de Paracoccidioides brasiliensis. Bol. Of. Sanit. Pan. Am. v.1, p.55-60, 1974.

MUELLER, D.L.; JENKINS, M.K.; \& SCHWARTZ, R.H. Clonal expansion versus functional clonal inactivation: a costimulatory signalling pathway determines the outcome of $\mathrm{T}$ cell antigen receptor occupancy. Annu. Rev. Immunol., v. 7, p. 445-480, 1989.

MURPHY, J.W.; WU-HSIEH, B.A.; SINGER-VERMES, L.M.; FERRANTE, .A; MOSER, S.; RUSSO, M.; VAZ, C.A.; BURGER, E.; CALICH, V.L.G.; KOWANKO, I.C. Cytokines in the host response to mycotic agents. J. Med. Vet. Mycol., v. 32, p. 203-210, 1994. 


\section{REFERÊNCIAS BIBLIOGRÁFICAS}

MUSATTI, C.C.; PERAÇOLI, M.T.S.; SOARES, A.M.V.C.; \& REZKALLAH-IWASSO, M.T. Cell-mediated immunity in patients with Paracoccidioidomycosis. In: Franco, M., Lacaz C.S., Restrepo, A.M. and Negro, G.D. Paracoccidioidomycosis Boca Ratón: CRC, p. 175-186, 1993.

NAIFF, R.D.; FERREIRA, L.C.; BARRETT, T.V.; NAIFF, M.F.; ARIAS, J.R. Enzootic Paracoccidioidomycosis in armadillos (Dasypus novemcinctus) in the State of Para. Rev. Inst. Med. Trop. São Paulo, v. 28(1), p. 19-27, 1986.

NASCIMENTO, F.R.; CALICH, V.L.G.; RODRIGUEZ, D.; RUSSO, M. Dual role for nitric oxide in Paracoccidioidomycosis: essential for resistance, but overproduction associated with susceptibility. J. Immunol., v. 168(9), p. 4593-4600, 2002.

NEGRONI, P. The Paracoccidioides brasiliensis lives saprophytically in the soil of Argentina. Prensa Med Argent., v. 53 (39), p. 2381-2382, 1966.

NURIEVA, R.I.; MAI, X.M.; FORBUSH, K.; BEVAN, M.J.; DONG, C. B7h is requerid fot T cell activation, differebtiation and effector function. Proc. Natl. Acad. Sci. USA, v. 100, p. 14163-14168, 2003.

OLIVEIRA, S.J.; MAMONI, R.L.; MUSATTI, C.C.; PAPAIORDANOU, P.M.; BLOTTA, M.H. Cytokines and lymphocyte proliferation in juvenile and adult forms of Paracoccidioidomycosis: Comparison with infected and non-infected controls. Microbes Infect., v. 4, p. 139-144, 2002.

PINA, A. (Tese). Atividade fungicida e secretora de macrófagos alveolares de camundongos susceptíveis e resistentes infectados pelo P. brasiliensis. São Paulo, São Paulo: Universidade de São Paulo, 2005, 118 pp. 


\section{REFERÊNCIAS BIBLIOGRÁFICAS}

PINA, A.; SALDIVA, P.H.; RESTREPO, L.E.; CALICH, V.L.G. Neutrophil role in pulmonary Paracoccidioidomycosis depends on the resistance pattern of hosts. J. Leukoc. Biol., v. 79(6), p. 1202-1213, 2006.

PINA, A.; VALENTE-FERREIRA, R. C.; VAZ, C. A. C.; MOLINARI-MADLUM, E. E. I. W.; KELlER, A. C.; CALICH, V. L. G. Absence of IL-4 determines a less severe pulmonary Paracoccidioidomycosis associated with impaired Th2 response. Infect. Immun., v. 72, p. 2369$2378,2004$.

PUPO, J.A. Evolução e formas clínicas de blastomicose sul-americana (Paracoccidioidomicose), J. Bras. Med., v. 9, p. 967-974, 1965.

RESTREPO, A. The ecology of Paracoccidioides brasiliensis: a puzzle still unsolved. J. Med. Vet. Mycol., v. 23, p. 323-334, 1985.

RESTREPO, A.; JIMENEZ, B.E. Growth of Paracoccidioides brasiliensis yeast phase in a chemically defined culture medium. J. Clin. Microbiol., v. 12(2), p. 279-281, 1980.

RESTREPO, A.; McEWEN, J.G.; CASTAÑEDA, E., The habitat of Paracoccidioides brasiliensis: how far from solving the riddle? Review. Med. Mycol., v. 39, p. 233-241, 2001.

RESTREPO, A.; McEWEN, J.G.; SALAZAR, M.E. The mycelial form of Paracoccidioides brasiliensis, In: Congress of the International Society for human and animal mycology., Proceedings. Barcelona: ISHAM, p. 143-148, 1988.

RESTREPO, A.; ROBLEDO, M.; GUTIERREZ, F.; SANCLEMENTE, M.; CASTANEDA, E.; CALLE, G. Paracoccidioidomycosis, (South American blastomycosis). A study of 39 cases observed in Medellin, Colombia. Am. J. Trop. Med. Hyg., v. 19 (1), p. 68-76, 1970. 


\section{REFERÊNCIAS BIBLIOGRÁFICAS}

RIBEIRO, L.R.R. (Dissertação). Caracterização do papel dos leucotrienos na paracoccidioidomicose (PCM) pulmonar e na atividade fungicida de macrógafos peritoneais pelo Paracoccidioides brasiliensis. São Paulo, São Paulo: Universidade de São Paulo, 2005, 106 pp.

ROSE, C.M.; KIMZEY, S.L.; GREEN, J.M. The host response of CD28 - deficient mice to Pneumocystis infection. Microbial pathogenesis, v. 40, p. 23-28, 2005.

RUDD, C.E.; \& SCHNEIDER, H. Unifying concepts in CD28, ICOS and CTLA-4 co-receptor signalling. Nat. Rev. Immunol., v. 3, p. 544-556, 2003.

SANO, A.; DEFAVERI, J.; TANAKA, R.; YOKOYAMA, K.; KURITA, N.; FRANCO, M.; COELHO, K.I.; BAGAGLI, E.; MONTENEGRO, M.R.; MIYAJI, M.; NISHIMURA, K. Pathogenicities and gp42kDa gene of three Paracoccidioides brasiliensis isolates originated from a nine-banded armadillo (Dasypus novemcintctus). Mycopathologia. v. 144, p. 61-65, 1998/1999a.

SANO, A.; TANAKA, R.; YOKOYAMA, K.; FRANCO, M.; BAGAGLI, E.; MONTENEGRO, M.R.; MIKAMI, Y.; MIYAJI, M.; NISHIMURA, K. Comparation between human and armadillo Paracoccidioides brasiliensis isolates by random amplified polymorphic DNA analysis. Mycopathologia., v. 143, p. 165-169, 1998/1999b.

SANTOS, W.A.; SILVA, B.M.; PASSOS, E.D.; ZANDONADE, E.; FALQUETO, A. Association between smoking and paracoccidioidomycosis: a case-control study in the State os Espírito Santo, Brazil. Cad. Sáude Pública, v. 19, p. 245-253, 2003.

SHARPE, A.H.; \& FREEMAN, G.J. The B-7/CD28 superfamily. Nat. Rev. Immunol., v. 2, p. 116-126, 2002. 


\section{REFERÊNCIAS BIBLIOGRÁFICAS}

SILVA-VERGARA, M.L.; MARTINEZ, R.; CHADU, A.; MADEIRA, M.; FREITAS-SILVA, G.; LEITE MAFFEI, C.M.; Isolation of a Paracoccidioides brasiliensis strain from the soil of a coffee plantation in Ibia, State of Minas Gerais, Brazil. Med. Mycol., v. 36 (1), p. 37-42, 1998.

SINGER-VERMES, L.M.; BURGER, E.; FRANCO, M.F.; MOSCARDI-BACCHI, M.; MENDES-GIANNINI, M.J.S.; CALICH, V.L.G. Evaluation of the pathogenicity and immunogenicity of seven Paracoccidioides brasiliensis isolates in susceptible inbred mice. $\mathbf{J}$. Med. Vet. Mycol., v.27, p. 71-82, 1989.

SINGER-VERMES, L.M.; CALDEIRA, C.B.; BURGER, E.; \& CALICH, V.L.G. Experimental murine Paracoccidioidomycosis: relationship among dissemination of the infection, humoral and cellular immune responses. Clin. Exp. Immunol., v. 94, p. 75-79, 1993.

SINGER-VERMES, L.M.; CIAVAGLIA, M.C.; KASHINO, S.S.; BURGER, E.; CALICH, V.L.G. The source of the growth-promoting factor(s) affects the plating efficiency of Paracoccidioides brasiliensis. J Med Vet Mycol., v. 30(3), p. 261-264, 1992.

SOARES, E.G.; LABUKI, K. Blastomicose sul-americana acompanhada desde a lesão de inoculação até o óbito. Apresentação de um caso. In: Congresso Brasileiro de Patologia, 10, Curitiba, 1974.

SOUTO, J.T.; ALIBERTI, J.C.; CAMPANELLI, A.P.; LIVONESI, M.C.; MAFFEI, C.M.; FERREIRA, B.R.; TRAVASSOS, L.R.; MARTINEZ, R.; ROSSI, M.A.; SILVA, J.S. Chemokine production and leukocyte recruitment to the lungs of Paracoccidioides brasiliensis infected mice is modulated by interferon-gamma. Am. J. Pathol., v. 163(2), p. 583-590, 2003. 


\section{REFERÊNCIAS BIBLIOGRÁFICAS}

SOUTO, J.T.; FIGUEIREDO, F.; FURLANETTO, A.; PFEFFER, K.; ROSSI, M.A.; SILVA, J.S. Interferon-gamma and tumor necrosis factor-alpha determine resistance to Paracoccidioides brasiliensis infection in mice. Am. J. Pathol., v. 156(5), p. 1811-1820, 2000.

SPACCAPElO, R., ROMANI, L., TONNETI, L., CENCI, E., MENCACCI, A., SERO, G., TOGNELlini, R., REED, S., PUCCETTI, P. AND BISTONI, F. TGF- $\beta$ important in determining the in vivo patterns of susceptibility or resistance in mice infected with Candida albicans. The Journal of Immunol. v.155, p.1349-1360, 1995.

TABORDA, C.P., JULIANO, M.A., PUCCIA, R., FRANCO, M., TRAVASSOS, L.R. Mapping the $\mathrm{T}$ cell epitope in the major 43-kilodalton glycoprotein of Paracoccidioides brasiliensis with induces a Th-1 response and protection against fungal infection in BALB/c mice. Infect. Immun. v.66, p.786-793, 1998.

TANG, Q., HENRIKSEN, K.J., BODEN, E.K., TOOLEY, A.J., YE, J., SUBUDHI, S.K., ZHENG, X.X., STROM, T.B., BLUESTONE, J.A. Cutting edge: CD28 controls peripheral homeostasis of CD4+CD25+ regulatory T cells. J. Immunol. v.171, p.3348-3352, 2003.

VAZ, C.A.; SINGER-VERMES, L.M.; CALICH, V.L.G. Comparative studies on the antibody repertoire produced by susceptible and resistant mice to virulent and nonvirulent Paracoccidioides brasiliensis isolates. Am J Trop Med Hyg., v. 59(6), p. 971-977, 1998.

VILLEGAS, E.N.; ELLOSO, M.M.; REICHMANN, G.; PEACH, R.; \& HUNTER, C.A. Role of $\mathrm{CD} 28$ in the generation of effector and memory responses required for resistance to Toxoplasma gondii. J. Immunol., v. 163, p. 3344-3353, 1999. 


\section{REFERÊNCIAS BIBLIOGRÁFICAS}

WALKER, L.S.; GULBRANSON-JUDGE, A.; FLYNN, S.; BROCKER, T.; RAYKUNDALIA, C.; GOODAlL, M.; FORSTER, R.; LIPP, M.; \& LANE, P. Compromised OX40 function in CD-28deficient mice is linked with failure to develop CXC chemokine receptor 5-positive CD4 cells germinal centers. J. Exp. Med., v. 8, p. 1115-1122, 1999. 
ANEXOS 


\section{ANEXO 1}

Quantificação de citocinas tipo 1 pulmonares e hepáticas após 72 horas, 2 e 10 semanas de infecção

\section{SOBRENADANTE DE PULMAO}

\begin{tabular}{|l|l|l|l|l|l|l|}
\hline \multirow{2}{*}{ CITOCINA } & \multicolumn{2}{|c|}{72 HORAS } & \multicolumn{2}{c|}{ 2 SEMANAS } & \multicolumn{2}{c|}{10 SEMANAS } \\
\cline { 2 - 7 } & WT & KO & WT & KO & WT & KO \\
\hline IL-12 & $15207,0 \pm 657,0$ & $15208,0 \pm 924,0$ & $14156,0 \pm 538,0$ & $15303,0 \pm 1179,0$ & $19168,0 \pm 693,0$ & $14277,0 \pm 195,0$ \\
\hline TNF- $\alpha$ & $9364,0 \pm 537,0$ & $10565,0 \pm 429,0$ & $12900,0 \pm 435,0$ & $11209,0 \pm 1723,0$ & $20839,0 \pm 244,0$ & $17716,0 \pm 386,0$ \\
\hline IL-2 & $84,0 \pm 33,0$ & $113,0 \pm 47,0$ & $401,0 \pm 159,0$ & $161,0 \pm 60,0$ & $191,0 \pm 42,0$ & $226,0 \pm 26,0$ \\
\hline IFN- $\gamma$ & $2087,0 \pm 427,0$ & $1795,0 \pm 662,0$ & $3226,0 \pm 325,0$ & $3762,0 \pm 846,0$ & $8760,0 \pm 617,0$ & $9057,0 \pm 747,0$ \\
\hline
\end{tabular}

\section{SOBRENADANTE DE FÍGADO}

\begin{tabular}{|l|l|l|l|l|l|l|}
\hline \multirow{2}{*}{ CITOCINA } & \multicolumn{3}{|c|}{72 HORAS } & \multicolumn{2}{c|}{ 2 SEMANAS } & \multicolumn{2}{c|}{10 SEMANAS } \\
\cline { 2 - 7 } & WT & KO & WT & KO & WT & KO \\
\hline IL-12 & ND & ND & $25249,0 \pm 0,1$ & $22248,0 \pm 1699,0$ & $20265,0 \pm 0,1$ & $18314,0 \pm 424,0$ \\
\hline TNF- $\alpha$ & ND & ND & $17139,0 \pm 567,0$ & $17054,0 \pm 962,0$ & $26015,0 \pm 0,1$ & $22931,0 \pm 675,0$ \\
\hline IL-2 & ND & ND & $692,0 \pm 99,0$ & $269,0 \pm 110,0$ & $1443,0 \pm 87,0$ & $1209,0 \pm 114,0$ \\
\hline IFN- $\gamma$ & ND & ND & $6405,0 \pm 144,0$ & $6256,0 \pm 560,0$ & $18608,0 \pm 970,0$ & $13869,0 \pm 1145,0$ \\
\hline
\end{tabular}




\section{ANEXO 2}

Quantificação de citocinas tipo 2 pulmonares e hepáticas após 72 horas, 2 e 10 semanas de infecção

\section{SOBRENADANTE DE PULMÃO}

\begin{tabular}{|l|l|l|l|l|l|l|}
\hline \multirow{2}{*}{ CITOCINA } & \multicolumn{2}{|c|}{72 HORAS } & \multicolumn{2}{c|}{ 2 SEMANAS } & \multicolumn{2}{c|}{10 SEMANAS } \\
\cline { 2 - 7 } & WT & KO & WT & KO & WT & KO \\
\hline IL-4 & $1,0 \pm 1,0$ & $13,2 \pm 12,0$ & $428,0 \pm 117,0$ & $234,0 \pm 50,0$ & $94,0 \pm 44,0$ & $65,0 \pm 40,0$ \\
\hline IL-5 & $1744,0 \pm 322,0$ & $1583,0 \pm 98,0$ & $1504,0 \pm 108,0$ & $1182,0 \pm 97,0$ & $929,0 \pm 44,0$ & $1237,0 \pm 59,0$ \\
\hline Il-10 & $1549,0 \pm 148,0$ & $1332,0 \pm 173,0$ & $1768,0 \pm 163,0$ & $1737,0 \pm 11,0$ & $4258,0 \pm 289,0$ & $4133,0 \pm 235,0$ \\
\hline
\end{tabular}

\section{SOBRENADANTE DE FÍGADO}

\begin{tabular}{|l|l|l|l|l|l|l|}
\hline \multirow{2}{*}{ CITOCINA } & \multicolumn{3}{|c|}{72 HORAS } & \multicolumn{2}{c|}{ 2 SEMANAS } & \multicolumn{2}{c|}{10 SEMANAS } \\
\cline { 2 - 7 } & WT & KO & WT & KO & WT & KO \\
\hline IL-4 & ND & ND & $995,0 \pm 146,0$ & $473,0 \pm 141,0$ & $1956,0 \pm 176,0$ & $1374,0 \pm 275,0$ \\
\hline IL-5 & ND & ND & $1647,0 \pm 147,0$ & $1408,0 \pm 108,0$ & $3202,0 \pm 245,0$ & $2246,0 \pm 352,0$ \\
\hline Il-10 & ND & ND & $3593,0 \pm 112,0$ & $3508,0 \pm 152,0$ & $8129,0 \pm 387,0$ & $5727,0 \pm 342,0$ \\
\hline
\end{tabular}




\section{ANEXO 3}

Quantificação do fator de crescimento e da quimiocina pulmonares e hepáticas após 72 horas, 2 e 10 semanas de infecção

\section{SOBRENADANTE DE PULMÃO}

\begin{tabular}{|l|l|l|l|l|l|l|}
\hline \multirow{2}{*}{ CITOCINA } & \multicolumn{2}{|c|}{72 HORAS } & \multicolumn{2}{c|}{ 2 SEMANAS } & \multicolumn{2}{c|}{ 10 SEMANAS } \\
\cline { 2 - 7 } & WT & KO & WT & KO & WT & KO \\
\hline GM-CSF & $549,0 \pm 127,0$ & $413,0 \pm 61,0$ & $1233,0 \pm 129,0$ & $956,0 \pm 68,0$ & $886,0 \pm 55,0$ & $999,0 \pm 76,0$ \\
\hline MCP-1 & $630,0 \pm 223,0$ & $365,0 \pm 159,0$ & $65,0 \pm 20,0$ & $145,0 \pm 123,0$ & $9,6 \pm 5,9$ & $1,0 \pm 1,0$ \\
\hline
\end{tabular}

\section{SOBRENADANTE DE FÍGADO}

\begin{tabular}{|l|l|l|l|l|l|l|}
\hline \multirow{2}{*}{ CITOCINA } & \multicolumn{2}{|c|}{72 HORAS } & \multicolumn{2}{c|}{ 2 SEMANAS } & \multicolumn{2}{c|}{ 10 SEMANAS } \\
\cline { 2 - 7 } & WT & KO & WT & KO & WT & KO \\
\hline GM-CSF & ND & ND & $2433,0 \pm 192,0$ & $1423,0 \pm 200,0$ & $4048,0 \pm 227,0$ & $2818,0 \pm 427,0$ \\
\hline MCP-1 & ND & ND & $1,0 \pm 1,0$ & $1,0 \pm 1,0$ & $37,0 \pm 31,0$ & $1,0 \pm 1,0$ \\
\hline
\end{tabular}




\section{ANEXO 4}

Quantificação de citocinas tipo 1 e tipo 2 pulmonares e hepáticas do experimento de sobrevida

\section{CITOCINAS TIPO 1}

SOBRENADANTE DE PULMÃO

\begin{tabular}{|l|l|l|}
\hline \multirow{2}{*}{ CITOCINA } & \multicolumn{2}{|c|}{ SOBREVIDA } \\
\cline { 2 - 3 } & \multicolumn{1}{|c|}{ WT } & \multicolumn{1}{c|}{ KO } \\
\hline IL-12 & $9800,0 \pm 854,0$ & $10677,0 \pm 499,0$ \\
\hline TNF- $\alpha$ & $6320,0 \pm 734,0$ & $7185,0 \pm 397,0$ \\
\hline IL-2 & $365,0 \pm 79,0$ & $327,0 \pm 56,0$ \\
\hline IFN- $\gamma$ & $2654,0 \pm 566,0$ & $3808,0 \pm 631,0$ \\
\hline
\end{tabular}

\section{SOBRENADANTE DE FÍGADO}

\begin{tabular}{|l|c|l|}
\hline \multirow{2}{*}{ CITOCINA } & \multicolumn{2}{|c|}{ SOBREVIDA } \\
\cline { 2 - 3 } & WT & \multicolumn{1}{|c|}{ KO } \\
\hline IL-12 & $11785,0 \pm 207,0$ & $11654,0 \pm 212,0$ \\
\hline TNF- $\alpha$ & $8127,0 \pm 394,0$ & $7948,0 \pm 202,0$ \\
\hline IL-2 & $1502,0 \pm 185,0$ & $957,0 \pm 91,0$ \\
\hline IFN- $\gamma$ & $5610,0 \pm 661,0$ & $4973,0 \pm 390,0$ \\
\hline
\end{tabular}

\section{SOBRENADANTE DE FÍGADO}

\begin{tabular}{|l|l|l|}
\hline \multirow{2}{*}{ CITOCINA } & \multicolumn{2}{|c|}{ SOBREVIDA } \\
\cline { 2 - 3 } & WT & KO \\
\hline IL-4 & $1033,0 \pm 126,0$ & $711,0 \pm 73,0$ \\
\hline IL-10 & $2648,0 \pm 278,0$ & $1983,0 \pm 133,0$ \\
\hline TGF- $\beta$ & $26784,0 \pm 1638,0$ & $23701,0 \pm 793,0$ \\
\hline GM-CSF & $4716,0 \pm 412,0$ & $3122,0 \pm 263,0$ \\
\hline
\end{tabular}




\section{ANEXO 5}

Quantificação de citocinas tipo 1 e tipo 2 pulmonares e hepáticas do experimento de imunoproteção

\section{CITOCINAS TIPO 1}

\section{SOBRENADANTE DE PULMÃO}

\begin{tabular}{|c|c|c|c|c|}
\hline \multirow{2}{*}{ CITOCINAS } & \multicolumn{2}{|c|}{ WT } & \multicolumn{2}{c|}{ CD28KO } \\
\hline & $\begin{array}{c}\text { NÃO } \\
\text { IMUNIZADOS }\end{array}$ & IMUNIZADOS & $\begin{array}{c}\text { NÃO } \\
\text { IMUNIZADOS }\end{array}$ & IMUNIZADOS \\
\hline IL-2 & $304,0 \pm 205,0$ & $79,0 \pm 78,0$ & $173,0 \pm 91,0$ & $74,0 \pm 16,0$ \\
\hline IL-12 & $10016,0 \pm 701,0$ & $10613,0 \pm 317,0$ & $9008,0 \pm 326,0$ & $10769,0 \pm 430,0$ \\
\hline IFN- $\gamma$ & $3887,0 \pm 912,0$ & $4499,0 \pm 14,0$ & $4360,0 \pm 782,0$ & $4412,0 \pm 371,0$ \\
\hline TNF- $\alpha$ & $3429,0 \pm 371,0$ & $3602,0 \pm 252,0$ & $2831,0 \pm 429,0$ & $3944,0 \pm 84,0$ \\
\hline
\end{tabular}

\section{SOBRENADANTE DE FÍGADO}

\begin{tabular}{|c|c|c|c|c|}
\hline \multirow{2}{*}{ CITOCINAS } & \multicolumn{2}{|c|}{ WT } & \multicolumn{2}{c|}{ CD28KO } \\
\hline & $\begin{array}{c}\text { NÃO } \\
\text { IMUNIZADOS }\end{array}$ & IMUNIZADOS & $\begin{array}{c}\text { NÃO } \\
\text { IMUNIZADOS }\end{array}$ & IMUNIZADOS \\
\hline IL-2 & $1856,0 \pm 668,0$ & $831,0 \pm 124,0$ & $1129,0 \pm 259,0$ & $1210,0 \pm 242,0$ \\
\hline IL-12 & $11200,0 \pm 0,1$ & $10992,0 \pm 124,0$ & $10974,0 \pm 225,0$ & $11200,0 \pm 0,1$ \\
\hline IFN- $\gamma$ & $5106,0 \pm 191,0$ & $4537,0 \pm 350,0$ & $4948,0 \pm 539,0$ & $5816,0 \pm 203,0$ \\
\hline TNF- $\alpha$ & $4040,0 \pm 0,1$ & $4007,0 \pm 33,0$ & $4040,0 \pm 0,1$ & $4040,0 \pm 0,1$ \\
\hline
\end{tabular}




\section{CITOCINAS TIPO 2}

\section{SOBRENADANTE DE PULMÃO}

\begin{tabular}{|c|c|c|c|c|}
\hline \multirow{2}{*}{ CITOCINAS } & \multicolumn{2}{|c|}{ WT } & CÑO & \\
& NÃO & & CD28KO \\
& IMUNIZADOS & IMUNIZADOS & IMUNIZADOS & IMUNIZADOS \\
\hline IL-4 & $208,0 \pm 150,0$ & $10,0 \pm 0,1$ & $60,0 \pm 59,0$ & $10,0 \pm 0,1$ \\
\hline IL-10 & $1120,0 \pm 452,0$ & $1341,0 \pm 779,0$ & $576,0 \pm 343,0$ & $1556,0 \pm 294,0$ \\
\hline TGF- $\beta$ & $19565,0 \pm 2792,0$ & $21337,0 \pm 234,0$ & $14577,0 \pm 38,0$ & $19695,0 \pm 177,0$ \\
\hline GM-CSF & $1400,0 \pm 349,0$ & $1422,0 \pm 231,0$ & $1248,0 \pm 290,0$ & $1692,0 \pm 610,0$ \\
\hline
\end{tabular}

\section{SOBRENADANTE DE FÍGADO}

\begin{tabular}{|c|c|c|c|c|}
\hline \multirow{2}{*}{ CITOCINAS } & \multicolumn{2}{|c|}{ WT } & \multicolumn{2}{c|}{ CD28KO } \\
\hline & NÃO & NÃO & \\
& IMUNIZADOS & IMUNIZADOS & IMUNIZADOS & IMUNIZADOS \\
\hline IL-4 & $2129,0 \pm 955,0$ & $887,0 \pm 165,0$ & $1148,0 \pm 225,0$ & $953,0 \pm 141,0$ \\
\hline IL-10 & $2382,0 \pm 176,0$ & $1511,0 \pm 133,0$ & $1420,0 \pm 344,0$ & $2328,0 \pm 135,0$ \\
\hline TGF- $\beta$ & $23578,0 \pm 87,0$ & $21600,0 \pm 894,0$ & $16679,0 \pm 163,0$ & $23938,0 \pm 356,0$ \\
\hline GM-CSF & $7658,0 \pm 3125,0$ & $5222,0 \pm 216,0$ & $4762,0 \pm 340,0$ & $4044,0 \pm 641,0$ \\
\hline
\end{tabular}


PUBLICAÇÃO 
PDF SEPARADO (ANEXADO AO MESMO CD)

PUBLICAÇÃO 
ANEXADO NESTE MESMO CD 